\author{
Universidade De São Paulo \\ Faculdade De Ciências Farmacêuticas \\ Programa de Pós-Graduação em Farmácia \\ Área de Toxicologia
}

\title{
AYAHUASCA NO TRATAMENTO DA FARMACODEPENDÊNCIA À COCAÍNA: POSSÍVEIS INTERVENÇÕES TERAPÊUTICAS?
}

Vítor Bruno

Dissertação para obtenção do Título de Mestre

Orientadora: Prof ${ }^{\mathrm{a}}$. Dr ${ }^{\mathrm{a}}$. Tania Marcourakis

São Paulo 


\author{
Universidade De São Paulo \\ Faculdade De Ciências Farmacêuticas \\ Programa de Pós-Graduação em Farmácia \\ Área de Toxicologia
}

\title{
AYAHUASCA NO TRATAMENTO DA FARMACODEPENDÊNCIA À COCAÍNA: POSSÍVEIS INTERVENÇÕES TERAPÊUTICAS?
}

\author{
Vítor Bruno \\ Versão Corrigida \\ Dissertação para obtenção do Título de Mestre \\ Orientadora: Prof ${ }^{\mathrm{a}}$. Dr ${ }^{\mathrm{a}}$. Tania Marcourakis
}

São Paulo 
Autorizo a reprodução e divulgação total ou parcial deste trabalho, por qualquer meio convencional ou eletronico, para fins de estudo e pesquisa, desde que citada a fonte.

Ficha Catalográfica elaborada eletronicamente pelo autor, utilizando o programa desenvolvido pela Seção Técnica de Informática do ICMC/USP e adaptado para a Divisão de Biblioteca e Documentação do Conjunto das Químicas da USP

Bibliotecária responsável pela orientação de catalogação da publicação: Marlene Aparecida Vieira - CRB - 8/5562

Bruno, Vítor
B845a Ayahuasca no tratamento da farmacodependência à cocaína: possíveis intervenções terapêuticas? / Vítor Bruno. - São Paulo, 2019.

$111 \mathrm{p}$.

Dissertação (mestrado) - Faculdade de Ciências Farmacêuticas da Universidade de São Paulo.

Departamento de Análises Clínicas e Toxicológicas. Orientador: Marcourakis, Tania

1. DMT. 2. alucinógenos. 3. dependência. I. T. II. Marcourakis, Tania, orientador. 


\title{
AYAHUASCA NO TRATAMENTO DA FARMACODEPENDÊNCIA À COCAÍNA: POSSÍVEIS INTERVENÇÕES TERAPÊUTICAS?
}

Comissão Julgadora da Dissertação

para obtenção do Título de Mestre

\author{
Prof $^{\mathrm{a}}$. Dr ${ }^{\mathrm{a}}$. Tania Marcourakis \\ Orientador/presidente
}

$1^{\circ}$ Examinador

$2^{\circ}$ Examinador

$3^{\circ}$ Examinador

$4^{\circ}$ Examinador

São Paulo, de de 2019. 
Dedico este trabalho ao meu pai, à minha mãe e à minha irmã. A melhor parte que existe em mim! 


\section{AGRADECIMENTOS}

A Deus, por ter me capacitado e ter aberto inúmeras portas durante meu mestrado.

À minha família, que apesar da distância, sempre acreditou no meu potencial e me deu todo auxílio possível para que eu possa correr atrás dos meus sonhos e torná-los possíveis. Eu amo vocês!

À Prof ${ }^{a}$. Dr ${ }^{a}$. Tania Marcourakis, por ter me aceitado no laboratório. Por ter acreditado e confiado no meu trabalho. Sou bastante grato a todas oportunidades que tive durante esse período. Obrigado por ter sido muito mais que uma orientadora, você foi uma "mãezona" para mim! Muito obrigado!

Ao Prof. Dr. Raphael Caio Tamborelli Garcia e à Prof ${ }^{a}$. Dr ${ }^{a}$. Larissa Helena Lobo Torres Pacheco pela discussão inicial do meu projeto e me ajudar a estruturar o delineamento experimental.

À Prof ${ }^{a}$. Dr ${ }^{a}$. Rosana Camarini pelo auxílio nas discussões dos meus resultados obtidos através dos experimentos comportamentais; e aos seus alunos por me receberem sempre muito bem no laboratório.

Ao Prof. Dr. Maurício Yonamine e sua equipe; em especial, Sarah, Gabi e Bia pela ajuda na caracterização analítica das drogas e nas dosagens plasmática.

À toda equipe de alunos do Laboratório de Neurotoxicologia da FCF/USP que esteve presente durante meu mestrado: Lídia, Ana Carolina, Sayuri, Stephanie, Sara, Vinícius, Jéssica e Gabi. Aprendi muito com vocês e sou absurdamente grato por ter tido essa maravilhosa experiência ao lado de vocês. Muito obrigado por me inspirarem!

Ao César Henrique Lobeiro por todo companheirismo e apoio emocional em todos esses anos. Muito obrigado por sempre estar presente quando preciso!

Aos meus inesquecíveis amigos de Ribeirão Preto, Ariel, Basso, DJ, Elo, Milan, Nikon, Simba, Tiozão, Tonho e Half, por acreditarem em mim e me incentivarem a sempre ir além!

A CAPES, CNPq e SENAD pelo auxílio financeiro.

O presente trabalho foi realizado com apoio da Coordenação de Aperfeiçoamento de Pessoal de Nível Superior - Brasil (CAPES) - Código de Financiamento 001. 
"If flowers can teach themselves how to bloom after winter passes, so can you." 


\section{RESUMO}

Bruno, V. Ayahuasca no tratamento da farmacodependência à cocaína: possíveis intervenções terapêuticas?. 2019. 111f. Dissertação (Mestrado em Farmácia: Fisiopatologia e Toxicologia). Universidade de São Paulo, São Paulo. 2019.

Alucinógenos $(A L U)$ são substâncias psicoativas que não induzem o indivíduo à dependência, possuem perfil de segurança de uso mais alto quando comparado a outras drogas e baixa capacidade de causar tolerância ao uso. Estudos recentes propõem o uso de ALU como tratamento a algumas doenças e transtornos relacionados ao sistema nervoso central, como a depressão, ansiedade e dependência. Dentre os ALU, a ayahuasca (AYA), cujo princípio ativo é a dimetiltriptamina (DMT), é uma bebida psicoativa amplamente utilizada pelas populações indígenas em rituais religiosos. Existem evidências de que pode ser eficaz no tratamento de dependência relacionada ao álcool e nicotina. No entanto, para a cocaína, a segunda droga ilícita mais utilizada no Brasil e na Europa, não existem muitos estudos. O objetivo deste trabalho foi avaliar o potencial da AYA em prevenir a expressão da sensibilização comportamental (SC) induzida pela cocaína e as repercussões neuroquímicas do tratamento em camundongos $\mathrm{C} 57 \mathrm{BI} / 6$. Para tanto, foi avaliada a influência da administração aguda de AYA $(1,76 ; 3,0 ; 17,6 ; 30,0$ mg/kg de DMT v.o.) na atividade locomotora dos animais em campo aberto (CA). Como não houve diferença estatística na distância percorrida durante a análise, as duas menores doses (1,76 e 3,0 mg/kg de DMT v.o.) foram escolhidas como doses iniciais para a realização do protocolo de prevenção à expressão da SC induzida pela cocaína. Inicialmente, os animais foram habituados no CA durante 3 dias consecutivos após a administração de solução salina $0,9 \%$ i.p. No $4^{\circ}$ dia experimental, os animais receberam, durante 10 dias alternados, cocaína $10 \mathrm{mg} / \mathrm{kg}$ ou salina 0,9\% i.p. e foram submetidos diretamente à avaliação da atividade locomotora no CA por 30 minutos. Vinte e quatro horas depois, receberam, durante 8 dias consecutivos, água ou AYA (1,76 ou 3,0 mg/kg de DMT v.o.) e após 30 minutos da administração, foram colocados no CA por 30 minutos para análise da atividade locomotora. No dia seguinte, os camundongos foram desafiados com uma administração de salina. $E$, no último dia experimental, foi realizado um desafio com cocaína, sempre colocando o animal no CA por 30 minutos. Nessas doses, a AYA não foi eficaz em prevenir a expressão da SC induzida pela cocaína. Dessa forma, avaliamos doses superiores de AYA (15, 30 e $45 \mathrm{mg} / \mathrm{kg}$ de DMT v.o.), as quais foram capazes de prevenir a expressão da SC à cocaína. Assim, o protocolo experimental foi novamente realizado com a menor dose (15 mg/kg de DMT v.o.), ao término do protocolo experimental, os animais foram eutanasiados e tiveram seu córtex pré-frontal, estriado e hipocampo dissecados para análise por immunoblotting dos receptores serotoninérgicos $5-\mathrm{HT}_{1 \mathrm{~A}} \mathrm{e}$ $5-\mathrm{HT}_{2 \mathrm{~A}}$. No entanto, não foram não observadas diferenças significativas ao comparar o nível proteico dos receptores nos grupos experimentais. Dessa forma, esses resultados sugerem que a AYA pode ser uma boa estratégia terapêutica para a dependência em cocaína, abrindo caminho para novos estudos.

Palavras chaves: DMT, alucinógenos, dependência 


\section{ABSTRACT}

Bruno, $V$. Ayahuasca in the treatment of cocaine addiction: possible therapeutic interventions?. 2019. 111s. Thesis (Master in Pharmacy: Pathophysiology and Toxicology). School of Pharmaceutical Sciences, University of São Paulo, São Paulo. 2019.

Psychedelics (PSY) are psychoactive substances that do not induce the individual to addiction, have a higher use safety profile when compared to other drugs and low ability to cause tolerance to use. Recent studies propose the use of PSY as a treatment for some diseases and disorders related to the central nervous system, such as depression, anxiety and addiction. Among the PSY, ayahuasca (AYA), whose active component is dimethyltryptamine (DMT), is a psychoactive drink widely used by indigenous populations in religious rituals. There is evidence that it may be effective in treating alcohol and nicotine addiction. However, for cocaine, the second most widely used illicit drug in Brazil and Europe, there are not many studies. The aim of this study was to evaluate the potential of AYA in preventing cocaine-induced behavioral sensitization (BS) expression and the neurochemical repercussions of this treatment in C57BI/6 mice. Thus, we evaluated the influence of acute administration of AYA (1.76; $3.0 ; 17.6 ; 30.0 \mathrm{mg} / \mathrm{kg}$ of DMT, orally) on the locomotor activity of animals in the open field (OF). As there was no statistical difference in the distance travelled during the analysis, the two lowest doses (1.76 and $3.0 \mathrm{mg} / \mathrm{kg}$ of DMT, orally) were chosen as initial doses to perform the cocaine-induced expression prevention protocol. First, animals were habituated to OF for 3 consecutive days following administration of saline $0.9 \%$ i.p. On the fourth experimental day, the animals received for 10 alternate days cocaine $10 \mathrm{mg} / \mathrm{kg}$ or saline $0,9 \%$ i.p. and were directly submitted to the evaluation of locomotor activity in OF for 30 minutes. Twenty-four hours later they received, for 8 consecutive days, water or AYA (1.76 or $3.0 \mathrm{mg} / \mathrm{kg}$ of DMT, orally), and 30 minutes after administration, they were placed in the OF for 30 minutes for analysis of locomotor activity. The next day, the mice were challenged with saline administration. On the last experimental day, a cocaine challenge was performed, always placing the animal in the OF for 30 minutes. At these doses, AYA was not effective in preventing cocaine-induced expression of BS. Thus, we evaluated higher doses of AYA (15, 30 and $45 \mathrm{mg} / \mathrm{kg}$ of DMT, orally), which were able to prevent the expression of cocaine-induced BS. Thus, the experimental protocol was again performed with the lowest dose (15 mg/kg of DMT, orally). At the end of the experimental protocol, the animals were euthanized and their prefrontal cortex, striatum and hippocampus were dissected for serotonergic receptor $5-\mathrm{HT}_{1 \mathrm{~A}}$ and $5-$ $\mathrm{HT}_{2 \mathrm{~A}}$ by immunoblotting. However, no significant differences were observed when comparing receptor protein level in the experimental groups. Thus, these results suggest that AYA may be a good therapeutic strategy for cocaine addiction, paving the way for further studies.

Keywords: DMT, psychedelics, addiction 


\section{SUMÁRIO}

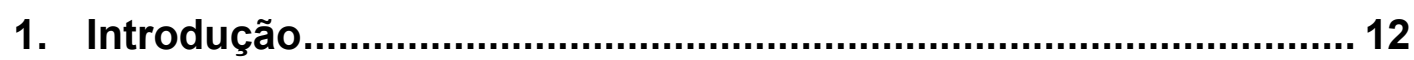

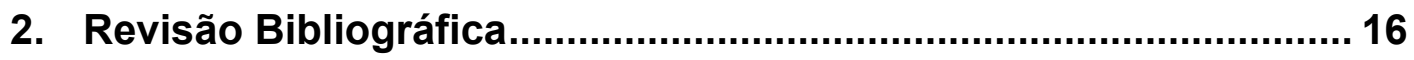

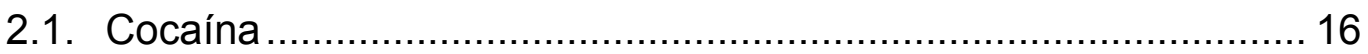

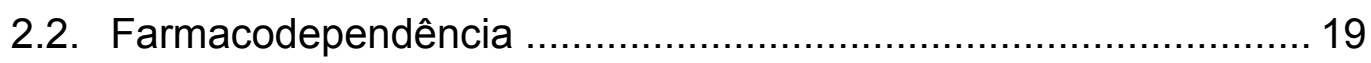

2.2.1. Neurobiologia do uso de drogas de abuso ............................. 21

2.2.2. Teoria da Sensibilização do Incentivo ..................................... 25

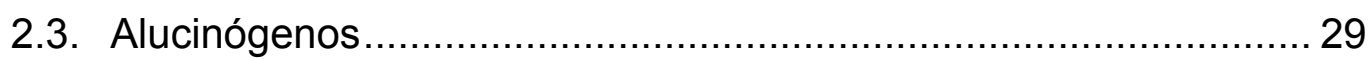

2.3.1. Redução de danos e o uso terapêutico dos alucinógenos ........ 31

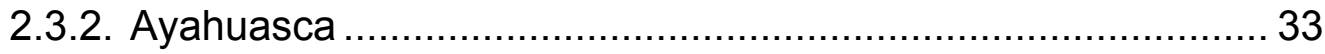

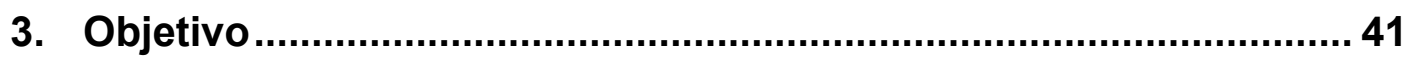

Para tanto, foram empregadas as estratégias experimentais: ............... 41

4. Material e Métodos..................................................................... 43

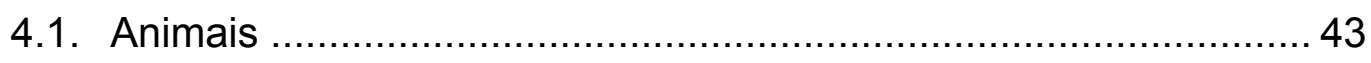

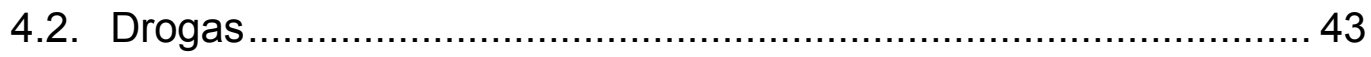

4.3. Caracterização analítica das drogas .......................................... 43

4.3.1. Avaliação do grau de pureza da cocaína por GC-MS .............. 43

4.3.2. Dosagem de cocaína e benzoilecgonina em amostras de plasma de camundongo por UPLC-ESI-MS/MS ……..................... 44

4.3.3. Dosagem dos alcaloides da ayahuasca em amostra de chá por

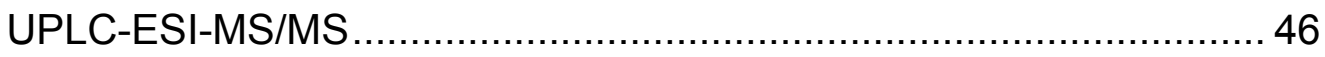

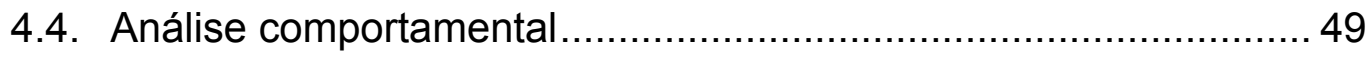

4.4.1. Análise da atividade locomotora no Campo Aberto.................. 49

4.4.2. Análise comportamental no Labirinto em Cruz Elevado ........... 49

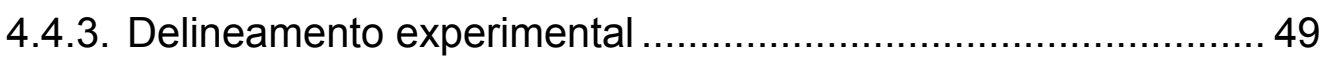

4.5. Análise proteica por immunoblotting ………………................. 56

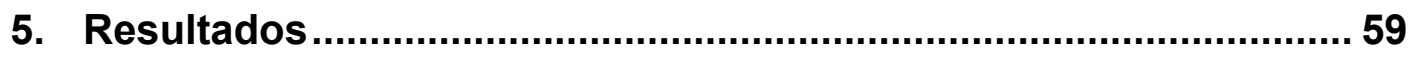

5.1. Caracterização analítica das drogas ........................................... 59

5.1.1. Avaliação do grau de pureza da cocaína por GC-MS .............. 59

5.1.2. Dosagem dos alcaloides da ayahuasca em amostra de chá por

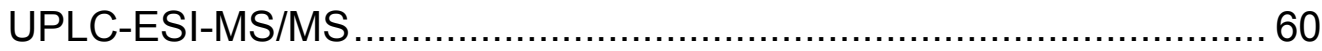


5.2. Avaliação da influência da ayahuasca na atividade locomotora de camundongos em campo aberto

5.3. Protocolo de prevenção da expressão da sensibilização

comportamental induzida pela cocaína com ayahuasca na dose de 1,76 $\mathrm{mg} / \mathrm{kg}$ de DMT 64

5.3.1. Análise da atividade locomotora no campo aberto 64

5.3.2. Análise comportamental no labirinto em cruz elevado

5.3.3. Dosagem de cocaína e benzoilecgonina em amostras de plasma de camundongo por UPLC-ESI-MS/MS

5.4. Avaliação do efeito agudo da ayahuasca ( $3 \mathrm{mg} / \mathrm{kg}$ de DMT) na atividade locomotora de camundongos em resposta à cocaína

5.5. Protocolo de prevenção da expressão da sensibilização comportamental induzida pela cocaína com ayahuasca na dose de 3 $\mathrm{mg} / \mathrm{kg}$ de DMT 70

5.6. Protocolo de prevenção da expressão da sensibilização comportamental induzida pela cocaína utilizando ayahuasca nas doses de 15,30 e $45 \mathrm{mg} / \mathrm{kg}$ de DMT

5.7. Protocolo de prevenção da expressão da sensibilização comportamental induzida pela cocaína com ayahuasca na dose de 15 $\mathrm{mg} / \mathrm{kg}$ de DMT

5.7.1. Avaliação da atividade locomotora em campo aberto 74

5.7.2. Análise proteica nas estruturas alvo por immunoblotting 77

6. Discussão 81

7. Conclusão 94

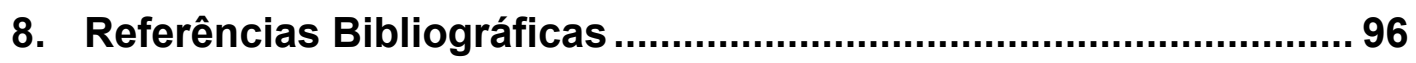

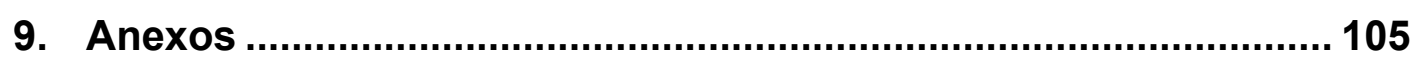

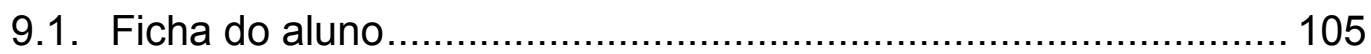

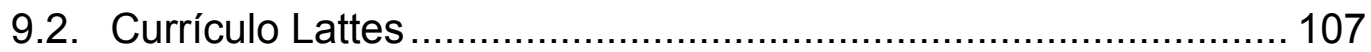

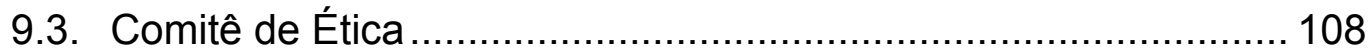

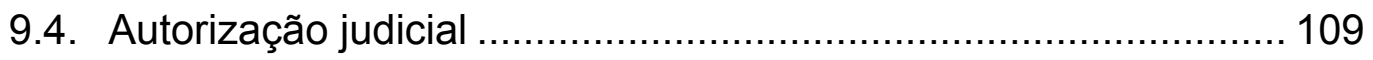


Introdução 


\section{Introdução}

De acordo com o último Relatório Mundial Sobre Drogas emitido pelo Escritório Das Nações Unidas Sobre Drogas e Crime, dados relacionados à produção, tráfico e consumo de drogas evidenciam o aumento do mercado mundial de cocaína. Nesse mesmo relatório, observa-se que em 2017, a produção global aumentou em aproximadamente $25 \%$, totalizando cerca de 1.976 toneladas. Além disso, a apreensão mundial de cocaína foi 13\% superior ao ano anterior, estabelecendo-se como a maior taxa já reportada. Ainda que 153 países de todas as regiões informaram tal apreensão, durante os anos de 2010 e 2017 cerca de 90\% dela ocorreram nas Américas, mais evidentemente na América do Sul (59\%), onde a produção e o consumo são intensos (UNODC, 2019) (Figura 1).

Figura 1. Quantidade global de cocaína apreendida de acordo com cada região; à esquerda, durante os anos de 1998 e 2017; à direita, em 2017. A estatística apresentada não faz distinção entre as diversas formas de administração da cocaína: cloridrato de cocaína, cocaina pasta, cocaína base e crack. Traduzido e adaptado do World Drug Report 2019, publicado pelo United Nations Office on Drug and Crime (2019).
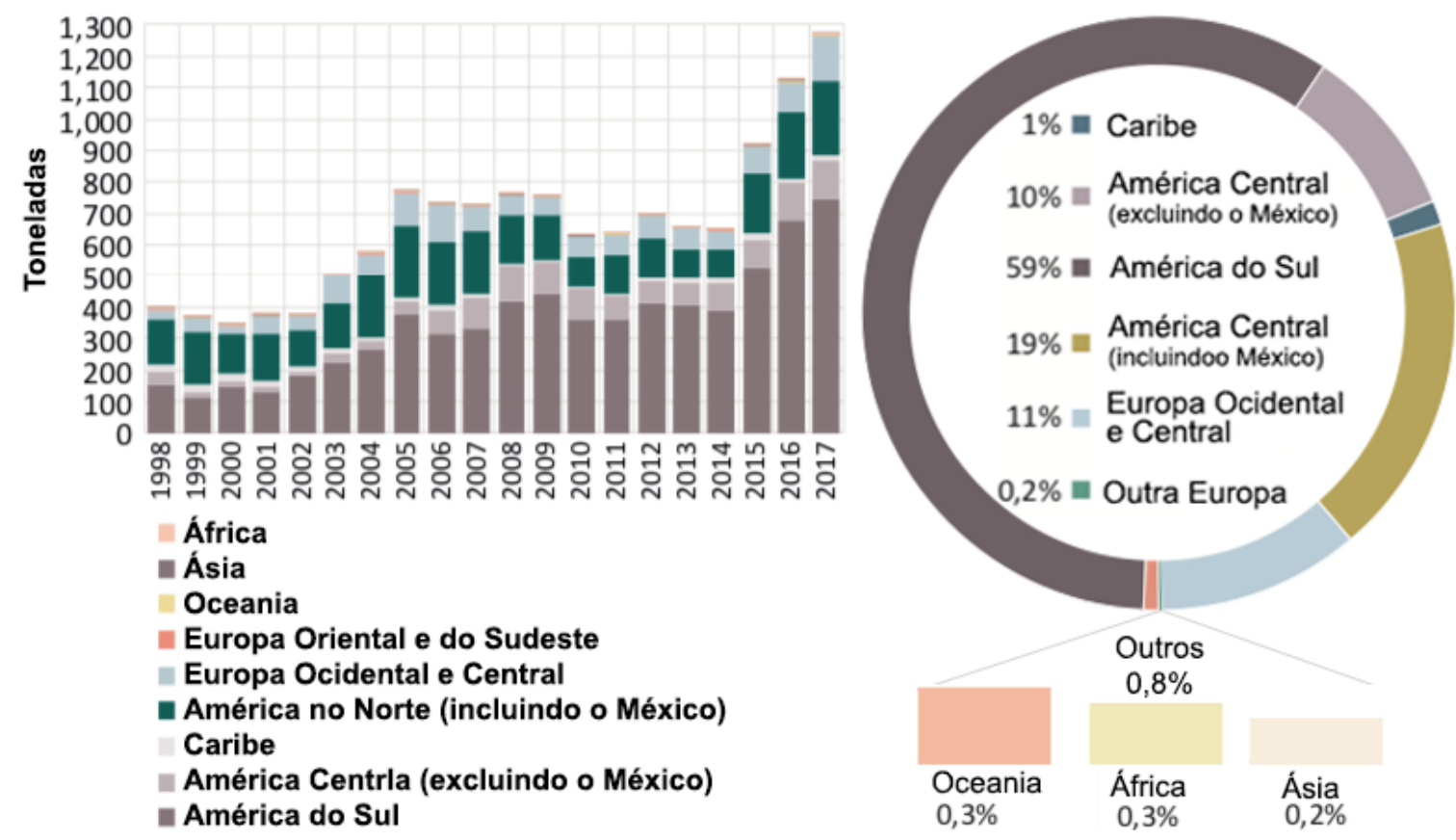

Considerando uma escala mundial, aproximadamente 18 milhões de pessoas fizeram o uso de cocaína, a qual foi a quinta droga mais utilizada em 2017 (UNODC, 2018); ocupando a segunda posição de droga ilícita mais consumida na Europa (EMCDDA, 2019) e no Brasil (III LNUD, 2017). 
Restringindo-se apenas ao território brasileiro, cerca de 4.683 .000 pessoas, de 12 a 65 anos, utilizaram cocaína pelo menos uma vez na vida: 1.340 .000 nos últimos 12 meses; e 461.000 nos 30 dias anteriores à pesquisa (III LNUD, 2017), como sugere a Figura 2.

Figura 2. Número de pessoas $(x 1.000)$ de 12 a 65 anos que consumiram substâncias ilícitas alguma vez na vida, nos últimos 12 meses e nos 30 dias anteriores à entrevista, por tipo de substância no Brasil em 2015. Adaptado do III Levantamento Nacional sobre o Uso de Drogas pela População Brasileira publicado pelo ICICT/FIOCRUZ, 2017).

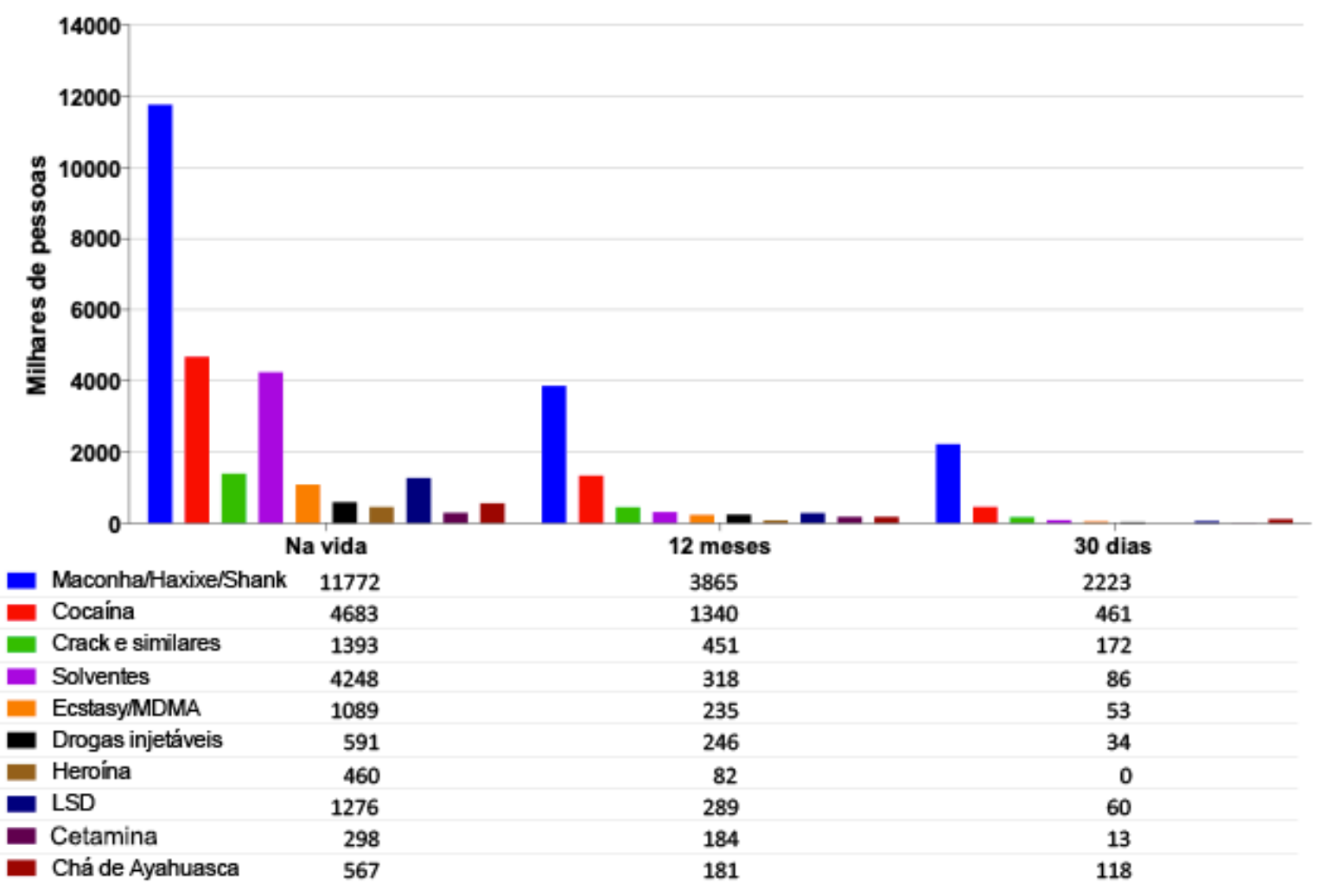

A cocaína pertence à classe de drogas denominadas psicoestimulantes, caracterizadas por propriedades reforçadoras intensas, aumento da excitação, ativação motora e elevado potencial de causar dependência (BERRIDGE e ARNSTEN, 2013)

Experimentos utilizando modelos animais para dependência de drogas de abuso fornecem dados sólidos para estudar as bases comportamentais e biológicas da dependência. Além disso, auxiliam a elucidar os mecanismos neurobiológicos envolvidos não apenas nos efeitos de reforço positivo desencadeado pelo uso dessas substâncias como também nos efeitos de reforço negativo evocados pela abstinência delas (PARVAZ et al., 2011). 
Atualmente, o tratamento da farmacodependência envolve abordagem multidisciplinar, com ações preventivas, grupos de autoajuda, acompanhamento psicológico e familiar, reabilitação neuropsicológica e psicossocial e redução de danos. Apesar de existirem fármacos que reduzem os transtornos desencadeados pela abstinência à cocaína, ainda não há um tratamento farmacológico completamente capaz de reverter os efeitos causados pela dependência gerada pelo uso abusivo dessa droga (CFM, 2011).

$\mathrm{Na}$ última década, tem se presenciado o ressurgimento do interesse científico no uso de substâncias alucinógenas na terapêutica de doenças psiquiátricas. Estudos evidenciam que o LSD foi capaz de reduzir os efeitos desencadeados pela farmacodependência ao etanol, bem como problemas pertinentes à dor, ansiedade e depressão (ALPER et al., 2018). O possível potencial terapêutico da ibogaína frente à dependência aos opiáceos (NOLLER et al., 2018); da psilocibina no caso do álcool e da nicotina (DE VEEN et al., 2017; JOHNSON et al., 2014); e do MDMA (ecstasy) na redução da síndrome pós-traumática também tem sido estudado (MITHOEFER et al., 2018). E, por fim, a ayahuasca, cujo principal princípio ativo é a N,Ndimetiltriptamina (DMT), tem sido estudada com o objetivo de restringir os efeitos relacionados à dependência ao tabaco, etanol, depressão e ansiedade (BOGENSCHUTZ e POMMY, 2012; MCKENNA, 2004). O uso de alucinógenos propõe uma perspectiva de redução de danos, a qual visa minimizar danos sociais e à saúde associados ao uso de substâncias psicoativas, uma vez que os alucinógenos representam uma classe de compostos cujos efeitos não induzem tolerância ou dependência e possuem maior índice de segurança (FRECSKA, 2007; JOHNSON, et al., 2008).

A ayahuasca, conhecida como chá do Santo Daime, é obtida pela decocção do cipó da espécie Banisteriopsis caapi com folhas da espécie Psychotria viridis. Juntas, possuem efeito sinérgico, uma vez que as $\beta$ carbolinas presentes nas folhas são inibidoras da enzima monoamina oxidase, que degrada a DMT. Dessa forma, a DMT torna-se disponível para realizar sua atividade psicoativa (HAMILL et al., 2019; MCKENNA, 2004). 
Revisão bibliográfica 


\section{Revisão Bibliográfica}

\subsection{Cocaína}

A cocaína é uma substância presente naturalmente nas folhas da planta do gênero Erythroxylon, encontrada na América do Sul, México e Indonésia. De todas as plantas Erythroxylon, as folhas da E. coca são as que possuem maior concentração de cocaína, aproximadamente $1 \%$ do seu peso (SHANNON, 1988; WARNER, 1993).

Para extrair a cocaína, as folhas da planta são maceradas com solventes, como querosene, até que se origine uma substância pastosa, a pasta de cocaína, a qual contém aproximadamente 40 a $80 \%$ de cocaína em sua composição. Em seguida, a pasta é submetida a um tratamento com ácido clorídrico, produzindo o cloridrato de cocaína, um pó branco e cristalino. O cloridrato de cocaína é solúvel em água e, portanto, bem absorvido pelas mucosas nasais e também pode ser administrado pela via intravenosa. Devido ao seu alto ponto de fusão, o cloridrato de cocaína não pode ser administrado pela via inalatória, devendo ser então convertida à cocaína base (freebase) ou crack pela extração com éter quando a mistura água-cloridrato de cocaína é tratado com amônia (CONE, 1995; SCHEIDWEILER et al., 2010)

Conforme observa-se na Tabela 1, a intensidade dos efeitos psicoestimulantes depende da via pela qual a droga é utilizada, sendo as principais intranasal, intravenosa e pulmonar. Para todas as vias de administração os efeitos desencadeados pela droga, tais como euforia, redução da fadiga, bem-estar, aumento da confiança e maior sensibilidade são os mesmos porém, variam em intensidade conforme a via. De fato, a rota pela qual a droga é administrada determina o quanto da dose alcançará o encéfalo e o quão rápido isso ocorrerá, sendo que quanto mais rápido a droga ultrapassa a barreira hematoencefálica, maior sua capacidade de provocar dependência (MARIE et al., 2018; VOLKOW et al., 2009). 
Tabela 1. Perfil toxicocinético da cocaína de acordo com as diferentes vias de administração.

\begin{tabular}{|c|c|c|c|c|c|}
\hline \multicolumn{2}{|c|}{ Administração } & \multirow{2}{*}{$\begin{array}{l}\text { Efeitos } \\
\text { iniciais }\end{array}$} & \multirow{2}{*}{$\begin{array}{l}\text { Duração dos } \\
\text { efeitos (min) }\end{array}$} & \multirow{2}{*}{$\begin{array}{l}\text { Dose média } \\
\text { aguda }\end{array}$} & \multirow{2}{*}{$\begin{array}{l}\text { Biodisponibilidade } \\
\text { (\% absorção) }\end{array}$} \\
\hline Via & Forma & & & & \\
\hline $\begin{array}{c}\text { Oral } \\
\text { Intranasal }\end{array}$ & $\begin{array}{l}\text { Folha de coca } \\
\text { Cloridrato de cocaína } \\
\text { Cloridrato de cocaína }\end{array}$ & $\begin{array}{c}5-10 \min \\
10-30 \min \\
2-3 \min \end{array}$ & $\begin{array}{c}45-90 \\
- \\
30-45\end{array}$ & $\begin{array}{c}20-50 \mathrm{mg} \\
100-200 \mathrm{mg} \\
5 \times 30 \mathrm{mg}\end{array}$ & $\begin{array}{l}20-30 \\
20-30\end{array}$ \\
\hline Intravenosa & Cloridrato de cocaína & $30-45 s$ & $10-20$ & $\begin{array}{c}25-50 \mathrm{mg} \\
>200 \mathrm{mg}\end{array}$ & 100 \\
\hline Pulmonar & $\begin{array}{l}\text { Coca pasta, } \\
\text { freebase } \\
\text { Crack }\end{array}$ & $8-10 s$ & $5-10$ & $\begin{array}{c}60-250 \mathrm{mg} \\
250-1000 \mathrm{mg} \\
-\end{array}$ & $6-32$ \\
\hline
\end{tabular}

Os indivíduos que se utilizam das vias que promovem picos plasmáticos da droga mais rapidamente utilizam-na com maior frequência e por maiores períodos de tempo. Além disso, investem mais recursos para persistir no uso, relatam mais perdas de controle da quantidade utilizada, possuem mais problemas de saúde associados e são mais susceptíveis às overdoses (RAWSON et al, 2007; RONCERO et al, 2012).

Uma vez no organismo, a cocaína é rapidamente metabolizada em metil éster ecgonina e benzoilecgonina, ambos excretados por via renal, representando 75 - 90\% do metabolismo. A metil éster ecgonina sofre ação das colinesterases hepáticas e séricas, enquanto a benzoilecgonina é formada por hidrólise não enzimática. Também é formada, em pequena quantidade, a norcocaína, a partir da desmetilação da cocaína pelo sistema oxidase de função mista hepática. Essa substância é um metabólito ativo muito potente, mas nas concentrações em que se forma (cerca de 5\%) não produz nenhum efeito adverso ao organismo (LEITE et al, 1999; CARRERA et al; 2004; GOODMAN et al; 2005).

A cocaína possui duas ações farmacológicas. Como anestésico local, bloqueia canais de sódio dependentes de voltagem, logo, a passagem desses íons pela membrana do axônio é comprometida, impedindo consequentemente, a despolarização e a transmissão do impulso elétrico. As propriedades psicoestimulantes, por sua vez, são decorrentes do bloqueio da recaptação de alguns neurotransmissores, como serotonina, noradrenalina e, principalmente, a dopamina devido à ligação da droga com os transportadores desses neurotransmissores, fazendo com que o indivíduo sinta os efeitos prazerosos da droga, conforme Figura 3 (KOOB et al., 2014). 
Figura 3. Atuação da cocaína no sistema nervoso central. (A) Funcionamento em condições fisiológicas da transmissão dopaminérgica. (B) Atuação da cocaína na fenda sináptica, bloqueando os transportadores de dopamina, impedindo a receptação desse neurotransmissor.

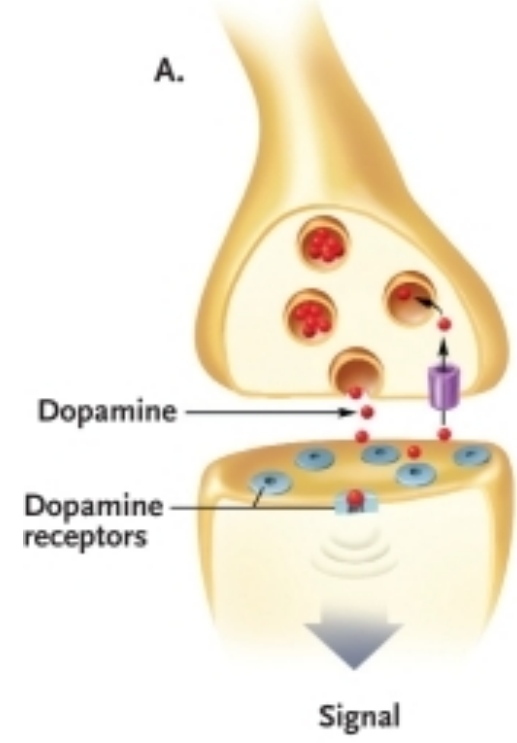

B.

Embora a maioria dos usuários, cerca de $85 \%$, não se tornem dependentes à droga, observações clinicas indicam que o uso controlado normalmente recai em uso abusivo, especialmente quando o acesso à droga é facilitado (ANTHONY et al, 1994). O uso crônico desse psicoestimulante desenvolve no indivíduo um padrão cíclico de uso. Inicialmente, há intensa euforia (high) desencadeada pela administração da droga, a qual possui acesso muito rápido ao sistema nervoso central, principalmente quando utilizada de forma intravenosa ou fumada (LEITE et al, 1999). Em seguida, o indivíduo desenvolve um quadro de disforia (crash). A intensidade com a qual ocorre a transição entre esses estados subjetivos depende diretamente da via de administração. O indivíduo pode apresentar estado de paranoia e, então, psicose quando a droga é utilizada em excesso, como ilustrado pela Figura 4 (KOOB e VOLKOW, 2010). 
Figura 4. Ciclo do padrão de uso de cocaína. Estágio 1 (euforia). Estágio 2 (disforia), marcado por tristeza, melancolia, apatia, dificuldade de concentração, anorexia e insônia. Estágio 3 (paranoia), marcado por paranoia (grandiosidade e perseguição), desconfiança, alucinação e insônia. Estágio 4 (psicose), marcado por anedonia, alucinação, comportamento estereotipado, perda do controle do impulso e desorientação. (Adaptado de Koob, 2014).

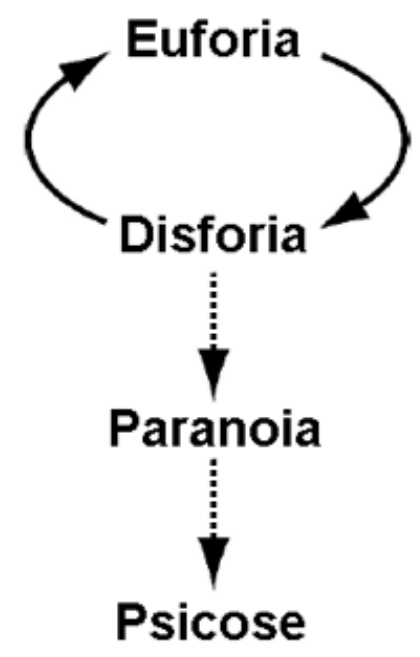

\subsection{Farmacodependência}

A farmacodependência é uma doença crônica caracterizada pela busca compulsiva e perda do controle de consumo de uma substância, bem como da quantidade administrada, e início de um estado emocional negativo quando o acesso à substância é privado (KOOB e VOLKOW, 2010).

Sabe-se que os usuários de drogas são motivados a usar a droga por duas razões: pelo desejo de retornar ao estado hedônico positivo induzido pela droga, a fim de vivenciar novamente os efeitos prazerosos ocasionados, e pela necessidade de evitar os sintomas não desejáveis da síndrome de abstinência (MARKOU e KOOB, 1991). Essa sensação de euforia provavelmente levará o indivíduo a um uso esporádico que pode evoluir para uso crônico ao longo do tempo. Cada experiência com drogas causará alterações significativas na atividade dopaminérgica no sistema de recompensa (KOOB \& VOLKOW, 2010; 2016)

Segundo Goldstein e Volkow (2002) o processo da farmacodependência pode ser entendido como uma síndrome do comprometimento da inibição da resposta e atribuição de saliência (impaired response inhibition and salience attribution, I-RISA) (Figura 5). Essa é 
formada por quatro estágios comportamentais conectados de forma cíclica sustentada por um reforço positivo, no qual a atividade desempenhada por regiões encefálicas como córtex pré-frontal e sistema de recompensa são diferentes em cada um desses componentes.

Figura 5. Síndrome do comprometimento da inibição da resposta e atribuição de saliência. $A$ intoxicação corresponde ao processo de administração da droga a curto prazo; o desejo é resultado de processos que geram uma resposta associativa entre o consumo da droga em determinado contexto e uma experiência prazerosa; a compulsão envolve administração da droga mesmo na presença de efeitos negativos; e abstinência, decorrente da interrupção do uso da droga. (Traduzido e adaptado de Goldstein \& Volkow, 2002).

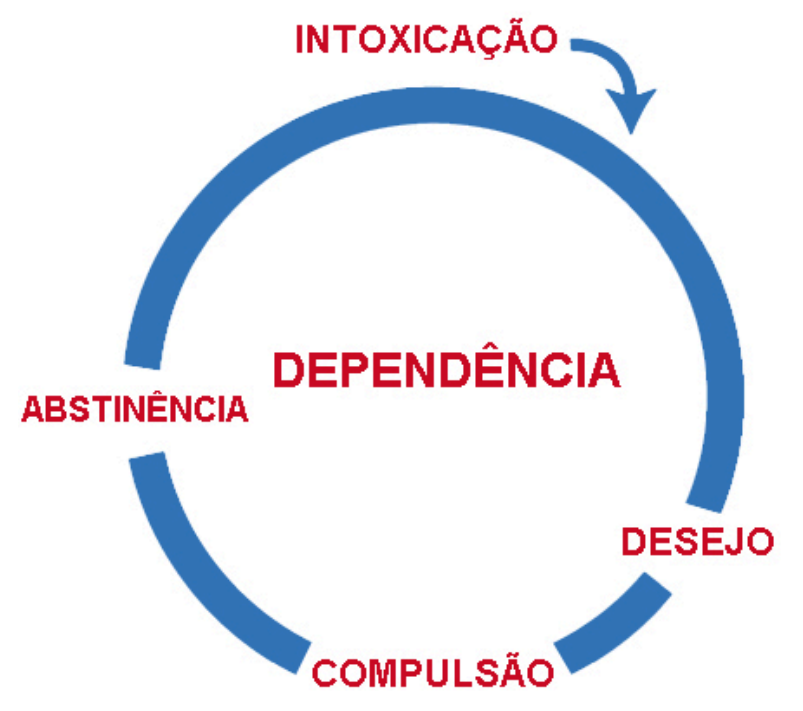

A fase de intoxicação por drogas de abuso está associada à experiência de seus fortes efeitos de reforço positivo exercido pela droga que são reforçados pela administração repetida da droga, fortalecendo o incentivo ao seu uso. Dessa forma, ocorre a hiperatividade das funções exercidas pelo córtex pré-frontal e pelo estriado ventral (VOLKOW et al., 1988, 1996; INGVAR et al., 1998).

Os estímulos externos associados ao contexto do uso da droga são hábeis em ativar circuitos motivacionais e salientar uma alta motivação para reforçar a autoadministração, o que está relacionado à atividade do hipocampo, da amigdala e do estriado dorsal. Assim desenvolve-se o estado de compulsão (bingeing), no qual a droga torna-se prioridade na vida do indivíduo e ele persiste no uso da droga mesmo que este seja danoso para seu bem-estar. A compulsão contribui tanto para a continuação e aumento da quantidade de droga consumida, quanto para a recaída (relapse). Durante 
essa fase, altos níveis de atividade na região do córtex pré-frontal e orbitofrontal são observadas, o que se correlaciona à "fissura" e ao desencadeamento de comportamentos de busca pela droga. Além disso, em indivíduos com transtorno de uso de substâncias, níveis mais elevados de ativação cerebral são observados em áreas límbicas quando expostos aos estímulos associados às drogas (GARAVAN et al., 2000; WEXLER et al., 2001).

Quando o indivíduo interrompe o uso da substância, após utilizá-la de forma intensa e por longos períodos de tempo, inicia-se o período de abstinência, o qual consiste na manifestação de sintomas físicos e psicológicos desagradáveis. A crise de abstinência, portanto, atua como reforço negativo, uma vez que a droga passa a ser desejada para impedir sua manifestação. Para os psicoestimulantes, como a cocaína, a síndrome de abstinência inicia-se de $12 \mathrm{~h}$ a 4 dias a partir do término do uso da droga. Os sintomas que se manifestam durante essa fase são opostos aos do período da intoxicação e incluem, para a cocaína, disforia, estado depressivo, anedonia, aumento do apetite, cansaço, confusão mental, irritabilidade e fissura intensa (BARR e MARKOU, 2005; COVINGTON e MICZEK, 2003).

\subsubsection{Neurobiologia do uso de drogas de abuso}

Estudos de estimulação elétrica cerebral demonstraram que o sistema mesolímbico dopaminérgico é uma das principais vias neuronais diretamente envolvidas com o processo de reforço positivo, e à transição do uso controlado de uma droga para a dependência (GOLDSTEIN e VOLKOW, 2002; KOOB e VOLKOW, 2010). Este é o principal substrato neurobiológico da dependência, uma vez que todas as drogas de abuso o ativam direta ou indiretamente (PARVAZ et al., 2011). O sistema mesolímbico dopaminérgico compreende corpos celulares de neurônios dopaminérgicos localizados na área ventral do tegmento mesencefálico que se projetam para estruturas límbicas, como o núcleo accumbens (DOBI et al., 2010). A ativação deste sistema é feita tanto por recompensas naturais quanto pelas drogas de abuso, porém a quantidade de dopamina liberada por estas últimas é muito maior e pode tornar esse circuito sensibilizado. 
A dopamina atua na regulação da atividade locomotora, nos processos de cognição e nos sistemas de motivação e recompensa (BANNON et al., 2005). Os processos de biossíntese, armazenamento e degradação deste neurotransmissor estão ilustrados pela Figura 6.

Figura 6. Biossíntese, armazenamento, transmissão e degradação da dopamina (DA). A síntese ocorre a partir da conversão da tirosina a L-dopa pela enzima tirosina hidroxilase, utilizando a 6-tetrahidrobiopterina como cofator. A L-dopa é convertida à dopamina pela enzima descarboxilase de aminoácido aromático (AADC). A dopamina é armazenada em vesículas pelo transportador vesicular de monoaminas (VMAT) até ser liberada na fenda sináptica após estímulo neuronal. A dopamina se liga a seus receptores na membrana póssináptica e o remanescente é inativado por oxidação pela enzima monoamina oxidase (MAO) localizada na mitocôndria ou por oxidação pela catecol-O-metiltanferase (COMT), dando origem ao ácido 3,4-di-hidroxifenilacético (Adaptado de Elsworth \& Roth, 1997 e Standaert \& Joshua, 2012).

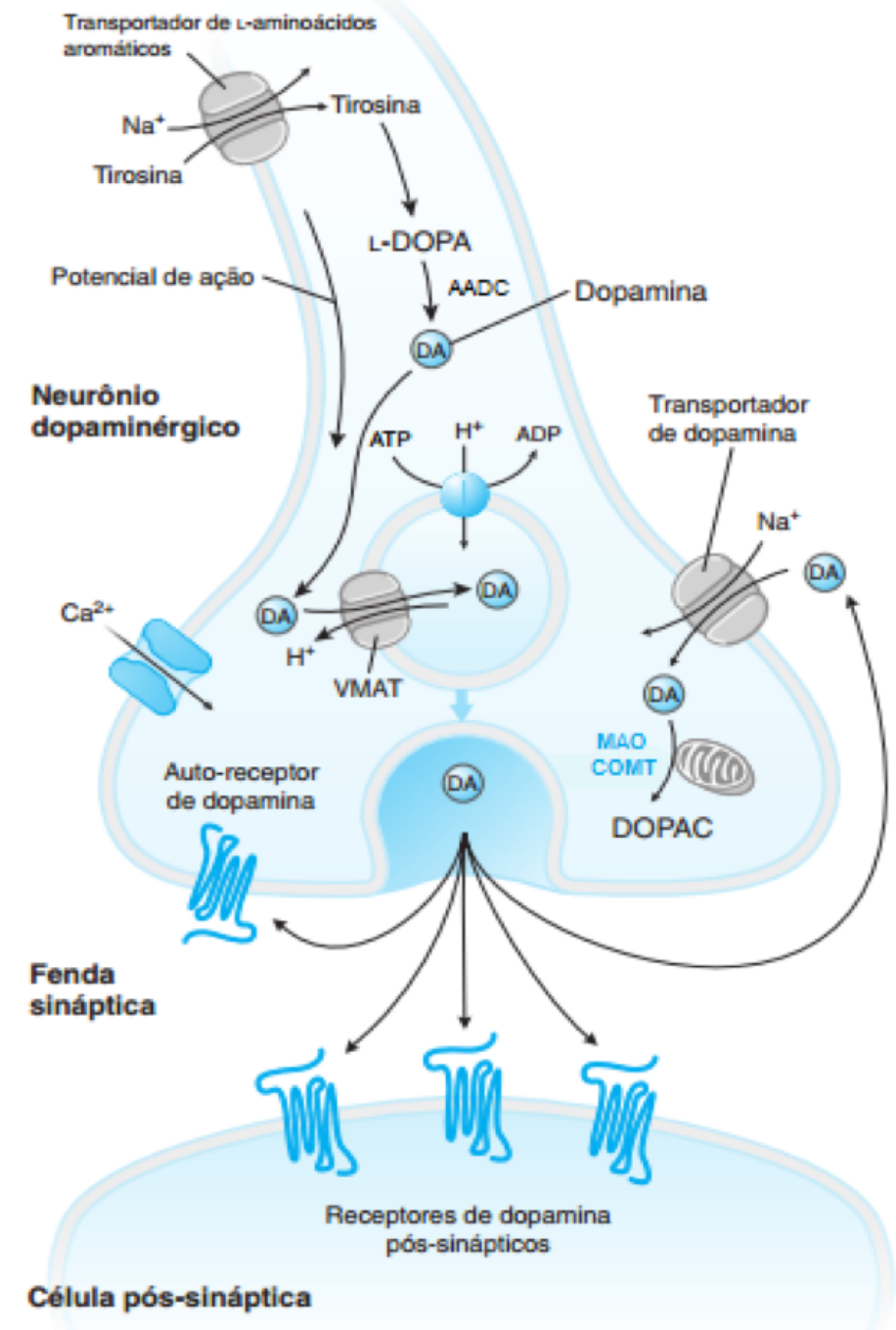


As ações fisiológicas relativas à dopamina (DA) são mediadas por cinco famílias de receptores acoplados à proteína $G$. Dois subtipos de receptores $D_{1}$-like $\left(D_{1}\right.$ e $\left.D_{5}\right)$ são acoplados à proteína $G_{S}$ que ativa a adenilil ciclase (AC). Os outros subtipos de receptores pertencem à família $D_{2}$-like $\left(D_{2}, D_{3}\right.$ e $\left.D_{4}\right)$ e são acoplados à proteína $G_{i}$ que inibem a $A C$ e ativam os canais de potássio (MISSALE et al., 1998; VALLONE et al., 2000). A distribuição dos receptores dopaminérgico está representada na Figura 7.

Figura 7. Localização dos receptores $D_{1}$-like e $D_{2}$-like Ambos os receptores $D_{1}$ e $D_{2}$ são mais expressos no núcleo caudado e putâmen (estriado), no núcleo accumbens, na tonsila do cerebelo, no tubérculo olfatório e no hipocampo. Além disso, os receptores $D_{1}$ são encontrados no córtex cerebral, enquanto os receptores $D_{2}$ estão presentes na substância negra, na área tegmental ventral e no hipocampo. ATV = área tegmentaL ventral, $C=$ núcleo caudado, $C x=$ córtex cerebral, $H=$ hipotálamo, $H I P P=$ hipocampo, $n A c=$ núcleo accumbens, $P=$ putâmen, $S N=$ substância negra, $T C=$ tonsila do cerebelo, $T O=$ tubérculo olfatório.
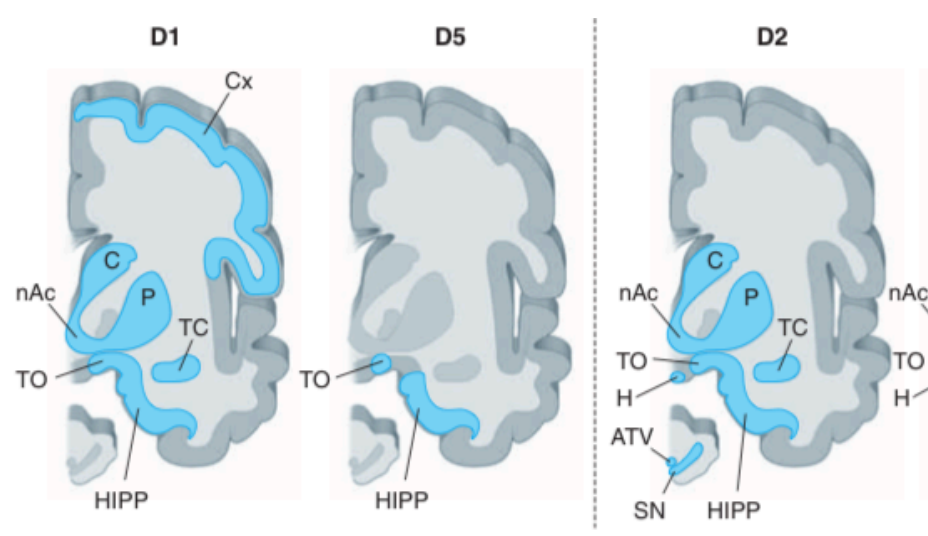

D3

D4
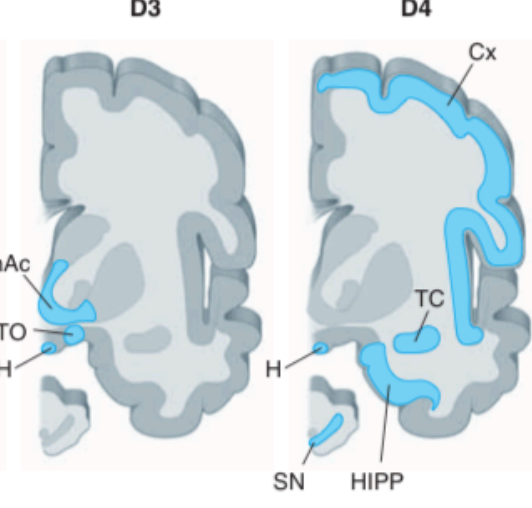

Além disso, sabe-se que todas as drogas de abuso compartilham algumas ações neuronais semelhantes devido à inibição dos neurônios espinhais médios no NAc via receptores acoplados à proteína $G_{i}$ (NESTLER, 2001). Nestler (2001) postula que estímulos repetidos nas vias de transdução de sinal intracelular modificam a função nuclear, alterando a taxa de transcrição de genes específicos e, como consequência, induzem a plasticidade neuronal (NESTLER, 2001; NESTLER, 2014).

Um fator de transcrição importante na plasticidade associada ao ciclo de dependência é a proteína de ligação ao elemento de resposta à adenosina monofosfato cíclico, AMPc (CREB). A CREB regula a transcrição de genes que contêm sítio de elemento de resposta ao $A M P c$ nas regiões reguladoras e pode ser encontrado de forma ubíqua em genes expressos no sistema 
nervoso central. A ativação da CREB no NAc é uma das consequências da exposição crônica a drogas de abuso, pois essas substâncias inibem agudamente a adenilil ciclase por meio de receptores acoplados à proteína Gi. O resultado de uma regulação positiva da via de AMPc é uma resposta homeostática compensatória de células em vários locais do sistema nervoso central (CARLEZON et al., 2005; NESTLER, 2005).

Essa upregulation da via do AMPc no NAc foi observada em várias regiões do encéfalo e há uma hipótese de desempenhar um papel não apenas nos efeitos físicos da abstinência à cocaína, mas também nos aspectos motivacionais. Ainda, essas adaptações moleculares diminuem a sensibilidade do indivíduo aos efeitos prazerosos das exposições anteriores à droga, prejudicando a via de recompensa pois ao retirar a droga o indivíduo entra em estado de desmotivação-depressão (CARLEZON et al., 2005).

Além disso, a regulação positiva dessa via também contribui para o aumento da expressão da dinorfina, que causa as respostas de disforia da droga. Ela constitui um mecanismo de feedback negativo neste circuito: a dinorfina, inicialmente liberada de terminais dos neurônios do núcleo accumbens, atua nos receptores K-opioides localizados nos terminais nervosos e nos corpos celulares dos neurônios dopaminérgicos, a fim de inibir seu funcionamento (CHAVKIN e KOOB, 2016). A exposição crônica à cocaína aumenta a atividade desse feedback negativo pela regulação positiva da via de AMPc, ativação de CREB e indução de dinorfina. No entanto, as alterações nesta via são relativamente curtas e podem não explicar mudanças de longo prazo associadas à propensão à recaída (ROBISON e NESTLER, 2011)

Ainda, a administração aguda de cocaína causa ativação rápida nos membros da família Fos, como Fras, c-Fos e FosB, outros fatores de transcrição. No entanto, as alterações moleculares associadas às mudanças de longo prazo devido à exposição crônica às drogas de abuso foram associadas às alterações em fatores de transcrição membros da família Fos (Figura 8). Tais fatores modificam a expressão gênica e produzem mudanças de longo prazo na expressão proteica e, como resultado, a atividade neuronal. $A \Delta F o s B$, por exemplo, acumula-se por longos períodos (dias) com administração crônica da droga (NESTLER, 2001; RUFFLE, 2014). Estudos 
sugerem que o aumento da concentração dessa proteína pode mediar o aumento da resposta locomotora, recompensa e comportamento de busca à cocaína (COLBY et al., 2003; KELZ et al., 1999).

Figura 8. Regulação das proteínas da família FosB frente à administração de cocaína (seta preta). O gráfico esquerdo mostra o aumento da concentração proteica da família Fos na região do NAc após uma única exposição à cocaína. O gráfico do lado direito, em contrapartida, mostra o acúmulo de isoformas de $\triangle F o s B$, uma vez que são altamente estáveis e, portanto, persistem no cérebro muito tempo após a exposição à droga (Traduzido e adaptado de Nestler et al, 2001).
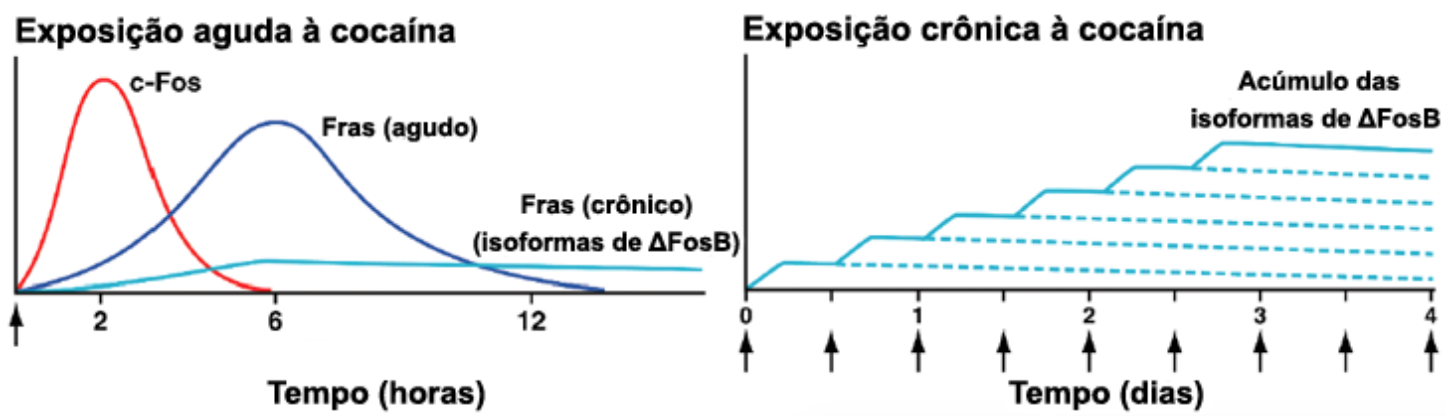

\subsubsection{Teoria da Sensibilização do Incentivo}

A Teoria da Sensibilização do Incentivo de Robinson e Berridge postula que o comportamento desencadeado pela farmacodependência é devido majoritariamente às neuroadaptações progressivas e persistentes ocasionadas pelo uso repetido de drogas (ROBINSON e BERRIDGE, 2008; ROBINSON e BERRIDGE, 1993; ROBINSON e KOLB, 2004). A sensibilização comportamental já foi estudada a partir da administração de diversas drogas, tais como: cocaína, anfetaminas, morfinas, etanol e nicotina (JOYCE e IVERSEN, 1979; ROBINSON e BECKER, 1986).

Ainda que a maioria das substâncias psicoativas tenham o potencial de induzir tolerância e farmacodependência, nem todos os indivíduos se sensibilizam a elas. Isso acontece devido a fatores de susceptibilidade individual, uma vez que o processo de sensibilização comportamental abrange fatores genéticos, hormonais, de gênero, experiências anteriores com o uso de drogas de abuso e também episódios de estresse no dia-a-dia (ROBINSON \& BECKER, 1986; ROBINSON \& KOLB, 2004).

A sensibilização comportamental pode ser observada em modelo animal por meio de estudos comportamentais que abrangem ativação dos efeitos psicomotores, como, por exemplo, aumento da atividade locomotora, 
comportamento rotacional ou então estereotipia motora (BERRIDGE e ARNSTEN, 2013; ROBINSON e BECKER, 1986; ROBINSON e BERRIDGE, 1993; SEGAL, 1975).

Esse fenômeno é definido como um aumento na sensibilidade dos circuitos neurais responsáveis pela atribuição de saliência de incentivo ("necessitar" de uma droga), um processo consequente de neuroplasticidade gradual e progressiva induzida ao longo do tempo pela constante presença da droga no sistema nervoso central e pelos estímulos ambientais condicionados ao uso da mesma. A atribuição de saliência de incentivo é mediada por projeções de dopamina da área tegmental ventral e da substância negra para o núcleo accumbens e regiões dorsais do estriado, respectivamente (BERRIDGE e ROBINSON, 2016; ROBINSON, BERRIDGE, 1993)

Robinson e Berridge (2003) ainda sugerem que o cérebro contém dois sistemas distintos, porém interconectados, essenciais ao processo da aquisição da sensibilização comportamental: um sistema responsável pelo prazer hedônico desencadeado pela droga, o chamado "liking" ("gostar"); e o "wanting", sistema responsável pelo "necessitar" da droga. Enquanto o "necessitar" é coordenado majoritariamente por sistemas mesocorticolímbico, em contraste a esse grande e robusto sistema, a via do "gostar" apresenta-se muito menor, sendo formada por pequenas porções fragilmente interconectadas (BERRIDGE e ROBINSON, 2016), conforme ilustrado pela Figura 9. 
Figura 9. Esquema das vias referentes ao "necessitar" e "querer" de Robinson e Berridge. "Necessitar" é mediado por um sistema cerebral robusto, incluindo projeções de dopamina (verde), enquanto "gostar" é mediado por um sistema cerebral restrito de pequenos pontos hedônicos (vermelho). Traduzido e adaptado de Berridge e Robinson, 2016).

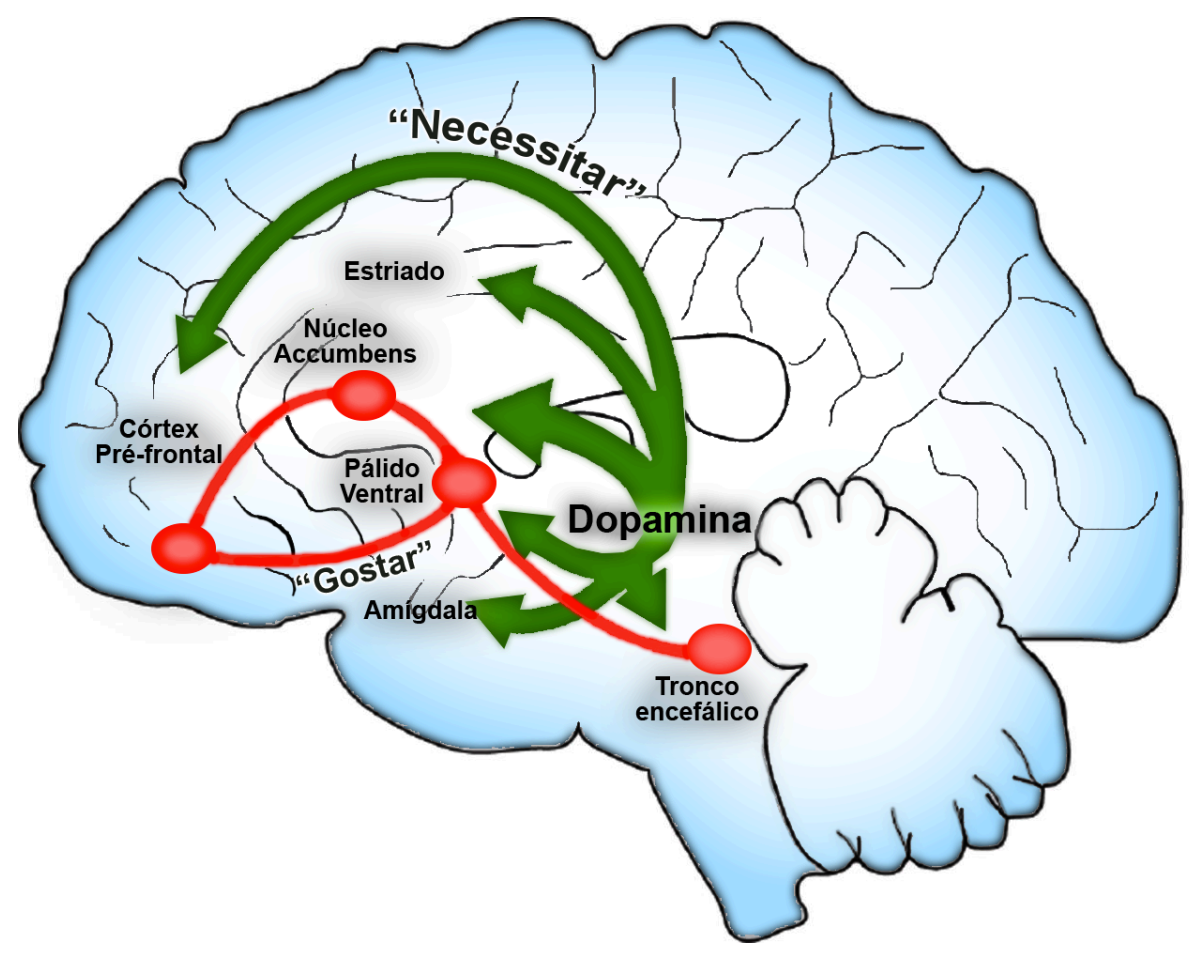

Diferentemente do "necessitar", o "gostar" da droga está associado a outros circuitos cerebrais e processos cognitivos, e não é sensibilizado. Logo, o cérebro sensibilizado não medeia os efeitos euforizantes ou hedônicos das drogas, mas desenvolve um subcomponente de recompensa então dito como incentivo à saliência à droga ("drug-wanting"). Assim, com o aumento da frequência do uso dessas substâncias, o "necessitar" se sobrepõe ao "gostar" (BERRIDGE e ROBINSON, 2016).

Assim, segundo essa teoria, a dependência é caracterizada pela progressiva dissociação do "necessitar" e do "gostar" de uma dada substância, com o aumento do incentivo à saliência sendo atribuído à droga e suas pistas ambientais. Dessa forma, as representações associadas à droga ganham então um incentivo, o qual aumenta a necessidade do indivíduo pela droga, de forma patológica. Portanto, expressam-se comportamentos de fissura pela droga, busca e consumo compulsivo da mesma (ROBINSON \& BERRIDGE, 1993; 2000).

A hipersensibilização na sinalização dopaminérgica resulta no aumento da saliência ao incentivo atribuída à droga e suas pistas ambientais, 
que, por sua vez, farão com que a droga seja "desejada" cada vez mais, motivando o usuário a aumentar o consumo. Assim, ocorre um aumento progressivo do "querer" e do consumo de drogas, sem qualquer aumento paralelo no "gostar" das drogas (ROBINSON \& BERRIDGE, 2003). Como resultado, a droga torna-se compulsivamente "desejada", na medida em que o desejo de consumir pode contradizer os desejos cognitivos de se abster, e as pistas associadas às drogas são capazes de desencadear desejos intensos, que podem resultar em fissura e busca pela droga (BERRIDGE \& ROBINSON, 2011).

As alterações neuroplásticas envolvidas no processo de aquisição da sensibilização de incentivo são de longa duração, as quais persistem ainda que o acesso à droga seja restrito e além da abstinência, que geralmente dura apenas 1 a 2 semanas (KHAVARI et al., 1975; STINUS et al., 1998; GEKHT et al., 2003). Esta última é caracterizada como um estado emocional negativo intenso acompanhado de disforia, ansiedade e irritabilidade, no que diz respeito à cocaína. As teorias de abstinência sugerem que esses sintomas desagradáveis são o principal motivador para o uso compulsivo de drogas, ocasionando em recaídas (KOOB et al.,1989).

No entanto, ainda que a abstinência possa ser uma razão importante para a recaída de muitos usuários, ela não explica o porquê de a recaída ocorrer com frequência mesmo após o desaparecimento dos sintomas de abstinência (HUNT et al., 1971). Contudo, isso pode ser explicado pelas alterações de neuroplasticidade induzidas pela sensibilização de incentivo, uma vez que as drogas e as pistas ambientais associadas a elas mantêm a capacidade de desencadear o desejo e a recaída por muitos anos. (ROBINSON et al., 2015). A Figura 10 sugere a construção de todo esse processo anteriormente mencionado. 
Figura 10. Esquema representativo do modelo da sensibilização do incentivo da dependência. A farmacodependência é definida, por Robinson e Berridge (2015), como uma dissociação progressiva das circuitarias do "necessitar" e "gostar" da droga com o aumento da saliência de incentivo sendo atribuída às drogas e suas pistas ambientais. Este modelo sugere uma via direta para a aquisição da dependência, a qual se desenvolve patologicamente com o consumo repetido e progressivo de drogas, levando à hipersensibilização do "necessitar" e do uso compulsivo de drogas. Ainda, um fator contribuinte separado para reforçar este fenômeno é destacado pela via indireta, que sugere que com o uso repetido das drogas, o prazer e a euforia causada pela droga não aumentam e às vezes até diminuem, o que leva a uma ingestão cada vez maior de uma dada substância. Finalmente, o uso compulsivo de drogas é muitas vezes pontuado por períodos de abstinência, que frequentemente resultam em recaída. Este "ciclo da recaída" caracteriza a dependência às drogas como um doença cíclica e crônica. (Traduzido e adaptado de Robinson et al., 2015).

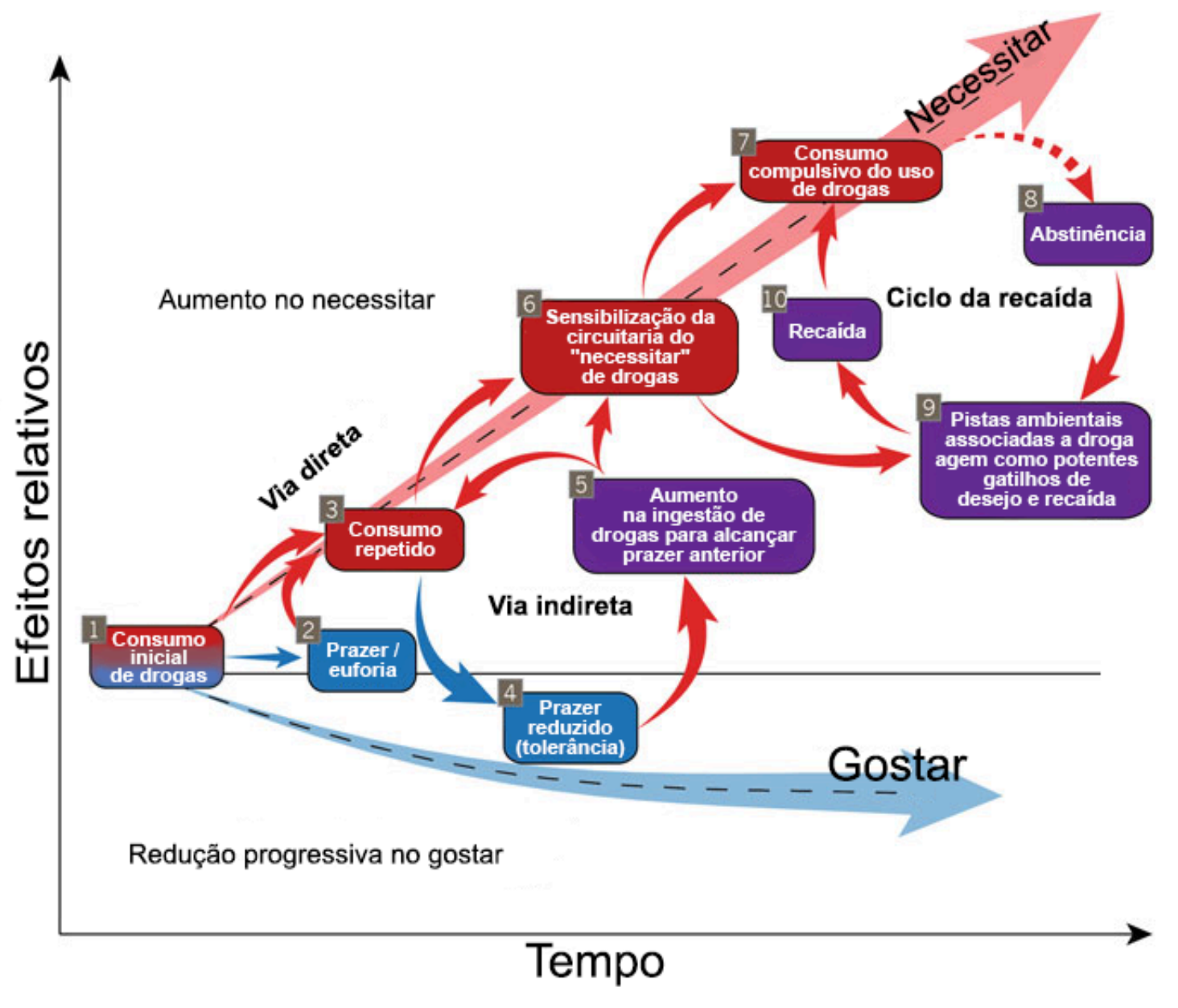

\subsection{Alucinógenos}

Os alucinógenos são substâncias psicoativas que alteram a percepção e humor, afetam inúmeros processos cognitivos, produzem reflexão, alterações de humor e percepção e flashes vívidos de memória (GRINSPOON e BAKALAR, 1997). Essa classe de drogas não pode ser completamente compreendida sem a presença de outras áreas do 
conhecimento, incluindo: antropologia, etnofarmacologia, psiquiatria, psicologia, sociologia e outras (NICHOLS, 2016).

Atualmente, os alucinógenos estão divididos em duas grandes classes: os alucinógenos clássicos ou típicos/tradicionais e os alucinógenos não clássicos, ou atípicos/não tradicionais. No primeiro grupo, encontram-se as substâncias análogas às fenetilaminas, como a mescalina, 3,4,5-trimetoxifenetilamina (derivada da família das cactáceas, incluindo o peiote); as triptaminas, como a 5-metoxidimetiltriptamina (5-MeO-DMT), a qual é produzida sinteticamente, mas também encontrada no veneno do sapo Bufo alvarius e em plantas; a DMT (N,N-dimetiltriptamina), encontrada na ayahuasca; a psilocibina (N,N-dimetil-4-fosforiloxitriptamina), que está presente nos cogumelos do gênero Psilocybe; e as ergolinas, como a dietilamida do ácido lisérgico (LSD) (BARSUGLIA et al., 2018; MURNANE, 2018). A estrutura molecular desses compostos está representada na Tabela 2 abaixo.

Tabela 2. Fórmula estrutural dos alucinógenos clássicos (como a mescalina, 5-MeO-DMT, DMT, psilocibina e LSD) e sua semelhança com a fenetilaminas.

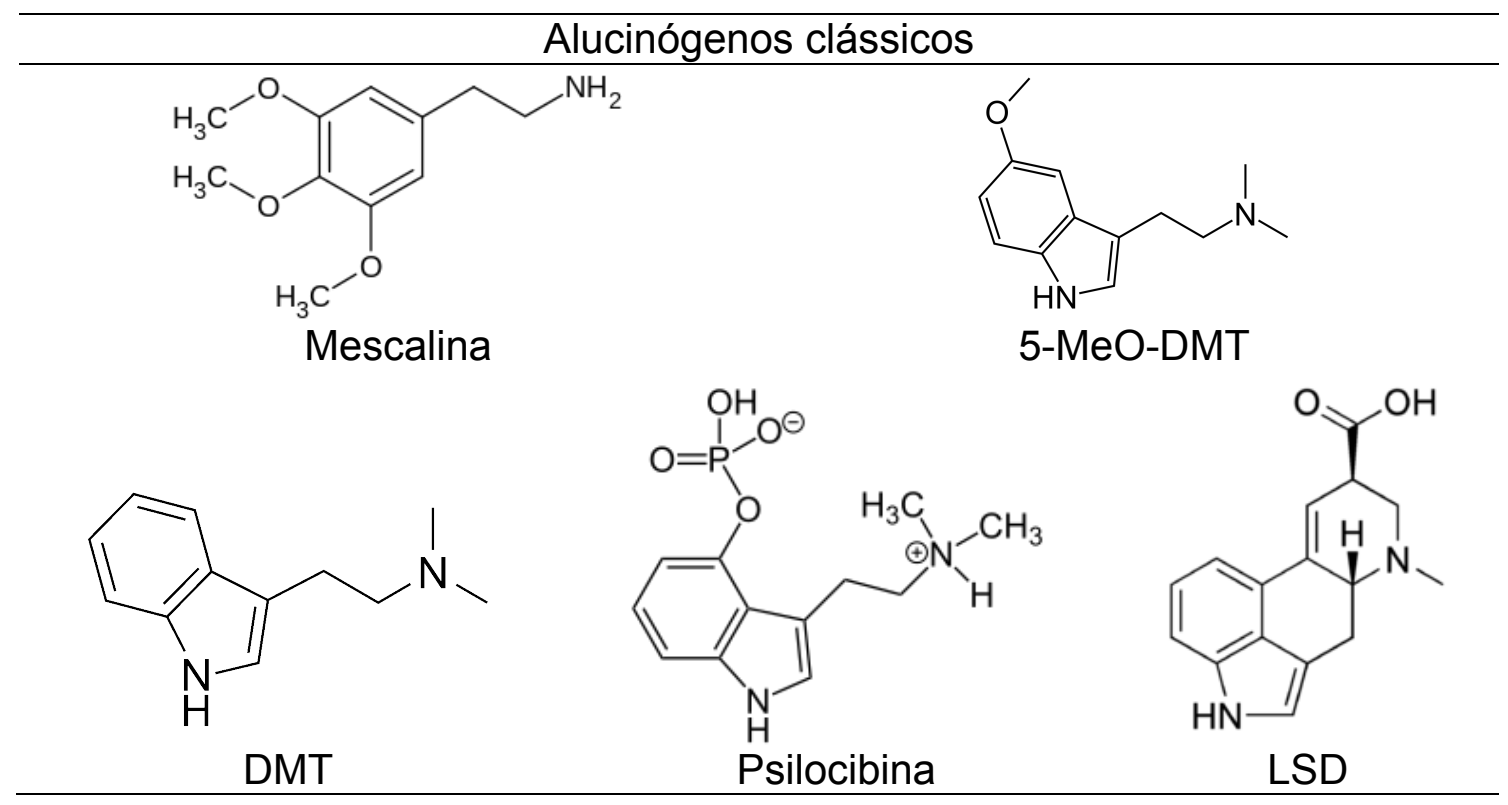

Já os alucinógenos atípicos podem ser subdivididos em (i) alucinógenos dissociativos, antagonistas do receptor $\mathrm{N}$-metil-D-aspartato (NMDA), dentre ele: os anestésicos fenciclidina (PCP) e cetamina, a ibogaína; (ii) agonistas de canabinoides, como o tetrahidrocanabinol $(\Delta 9$ - 
THC) da cannabis; (iii) antagonistas de receptores muscarínicos, como escopolamina inicialmente sintetizada para anestesia; e (iv) e os entactógenos, como 3,4-metilenodioximetanfetamina (MDMA), conhecido como ecstasy. Na Tabela 3, encontra-se a estrutura molecular dos alucinógenos não clássicos.

Tabela 3. Fórmula estrutural dos alucinógenos não clássicos (como a escopolamina, cetamina, tetrahidrocanabinol, ibogaína, fenciclidina e o MDMA).

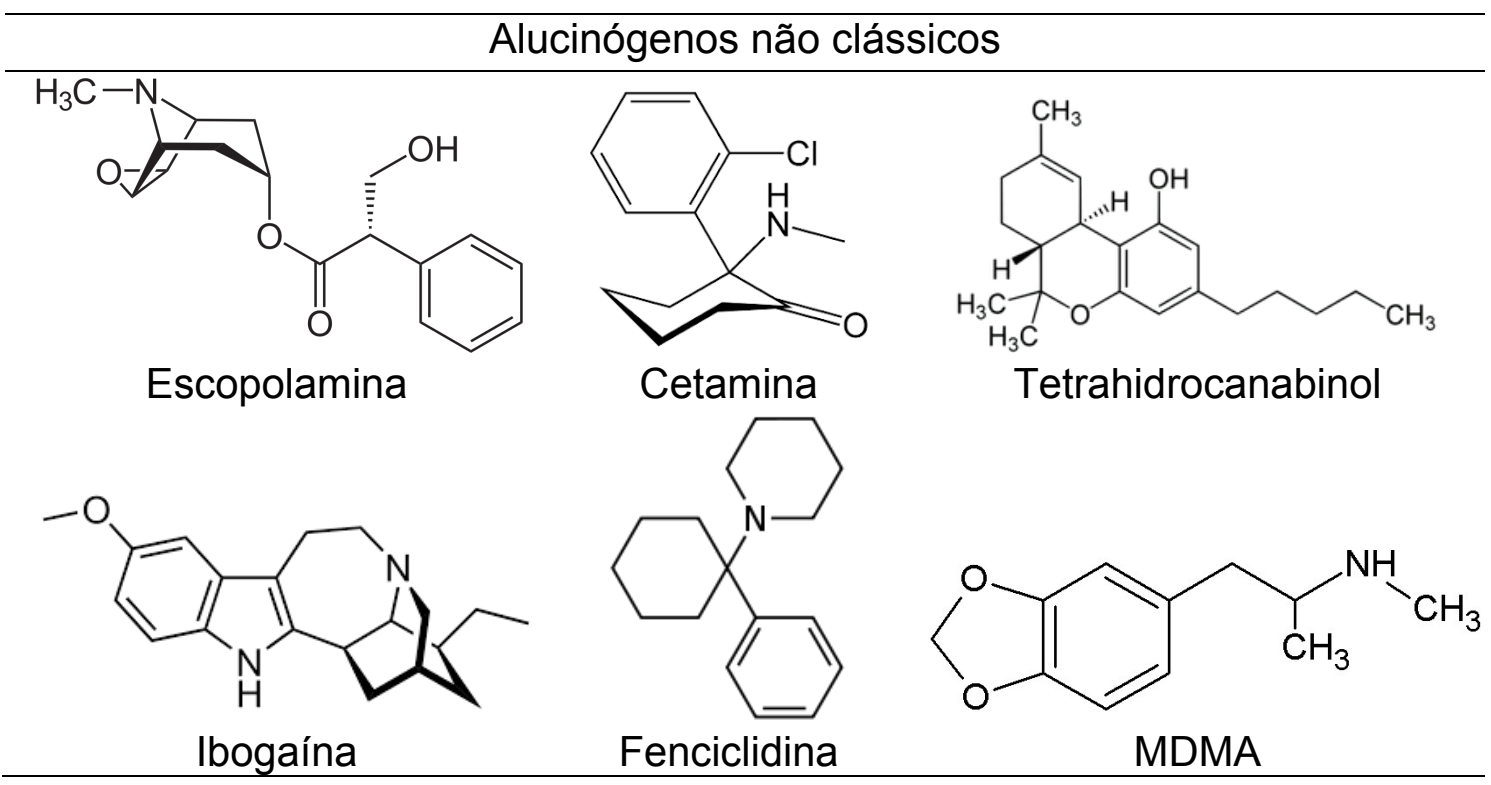

Os alucinógenos clássicos estimulam o sistema serotoninérgico principalmente por meio dos receptores $5-\mathrm{HT}_{1 \mathrm{~A}}, 5-\mathrm{HT}_{2 \mathrm{~A}}, 5-\mathrm{HT}_{2 \mathrm{C}}$ e $5-\mathrm{HT}_{7}$, com o sistema dopaminérgico principalmente via receptores $D_{2}$ e indiretamente com os sistemas glutamatérgico e GABAérgico, ao passo que certos alucinógenos atípicos têm afinidade direta por numerosos sistemas neurotransmissores (BARSUGLIA et al., 2018; MURNANE, 2018).

\subsubsection{Redução de danos e o uso terapêutico dos alucinógenos}

A redução de danos é uma política de prevenção dos danos potenciais relacionados ao uso de drogas, aceitando o fato que o uso de drogas persistiu apesar de todos os esforços para evitá-lo, e continuará a ser feito. Além disso, reconhece que as medidas destinadas a evitar o uso de drogas muitas vezes tiveram o efeito não intencional de aumentar os danos associados ao seu uso. Essa estratégia também foi chamada de limitação de 
danos, redução de acidentes ou minimização de danos (DUNCAN et al., 1994).

Uma abordagem de redução de danos poderia oferecer uma chance maior de mitigar as consequências negativas do abuso de drogas no futuro, porque considera a dinâmica realista do consumo humano de drogas em nosso passado (DUNCAN et al, 1994).

$\mathrm{Na}$ última década, tem-se presenciado o ressurgimento do interesse científico dos alucinógenos na terapêutica. Embora haja uma percepção de que os alucinógenos sejam perigosos, do ponto de vista fisiológico, eles representam uma das classes mais seguras conhecidas de drogas. De fato, eles não induzem o indivíduo à dependência, possuem baixo potencial para induzir tolerância e nenhuma morte por overdose ocorreu após a ingestão de doses típicas de LSD, psilocibina ou mescalina (NICHOLS, 2016). O risco mais comum é a angústia causada durante a ação da droga, chamada comumente de bad trip e, o menos comum é a psicose de longa duração (JOHNSON et al., 2008).

Os problemas de saúde mental são endêmicos em todo o mundo, e o suicídio é uma das principais causas de morte. Dessa forma, Hendricks e colaboradores (2015), avaliaram as relações do uso de alucinógenos clássicos com sofrimento psicológico e suicídio entre os mais de 190.000 adultos dos Estados Unidos. O uso dessas substâncias durante a vida foi associado a redução significativa das chances de sofrimento psicológico, no pensamento suicida, no planejamento suicida e na tentativa de suicídio, ao passo que o uso de drogas ilícitas está amplamente associado a uma maior probabilidade desses desfechos.

Ainda, é importante ressaltar que essas substâncias funcionam como tratamento para pacientes que não respondem aos outros considerados como convencionais (CARHART-HARRIS et al., 2018; PALHANO-FONTES et al., 2019). Atualmente, o grande foco das pesquisas com alucinógenos se destina à aplicação terapêutica dessas substâncias no tratamento de distúrbios psiquiátricos. Os compostos mais estudados nesse âmbito são: o LSD, o MDMA, a ibogaína, psilocibina e a DMT por meio da ayahuasca (TUPPER et al., 2015). 
Alper et al. (2018) mostraram que em camundongos C57BI/6 tratados com $50 \mu \mathrm{g} / \mathrm{kg}$ de LSD, o consumo de etanol foi reduzido, assim como a preferência ao etanol, com redução média do consumo de etanol de 17,9\% durante um intervalo de 46 dias seguindo a administração do LSD.

Em um estudo aberto avaliando dez pacientes com dependência ao álcool, o tratamento com psilocibina reduziu significativamente o consumo de álcool desde seu início até 36 semanas (BOGENSCHUTZ et al., 2015). Ainda, o tratamento de 15 pacientes com dependência ao tabaco e resistentes aos tratamentos convencionais, mostrou que $80 \%$ dos pacientes permaneceram em abstinência ao tabaco após seis meses de tratamento com psicoterapia assistida associada à psilocibina (JOHNSON et al., 2014)

Grupos de autoajuda americanos e europeus forneceram 191 depoimentos de que a ibogaína aliviou o desejo por drogas e os sintomas de abstinência relacionados aos opioides após administração de uma única dose. Para testar se a ibogaína foi eficaz no tratamento, foram utilizados questionários de compulsão multidimensional durante a desintoxicação dos pacientes internados. Não houve eventos adversos significativos após a administração de ibogaína (MASH et al., 2018).

No entanto, há uma limitação da terapia assistida por alucinógenos para doenças relacionadas ao sistema nervoso central: como essas substâncias produzem o estado profundo de consciência alterada, elas não devem ser prescritas para automedicação em casa; as sessões de terapia requerem supervisão de uma equipe multidisciplinar (FRECSKA, 2007; JOHNSON, et al., 2008).

\subsubsection{Ayahuasca}

Dentre as diversas plantas psicotrópicas utilizadas pelas populações indígenas, talvez nenhuma seja tão interessante ou complexa a nível botânico, químico ou então etnológico quanto a bebida psicoativa conhecida como ayahuasca, tradicionalmente utilizada em rituais xamânicos realizados na Amazônia (MCKENNA, Dennis J, 2004). O nome ayahuasca é um termo de origem quéchua, que pode ser compreendido como "trepadeira das almas" (aya - pessoa, alma, espírito; waska - corda), a qual faz alusão ao cipó 
utilizado como base no seu preparo. Além deste nome, essa bebida também é chamada de hoasca, daime, chá do santo daime, iagê (SANTOS, 2007). Atualmente, essa bebida tem sido utilizada por mais de 70 grupos indígenas diferentes, considerando apenas a América do Sul. Países como o Brasil, Colômbia, Peru, Venezuela, Bolívia e Equador utilizam-na em rituais religiosos do Santo Daime, Barquinha e União do Vegetal (DOMíNGUEZCLAVÉ et al., 2016).

O preparo do chá consiste na decocção de diferentes espécies do cipó Banisteriopsis, pertencente à família botânica Malpighiaceae, juntamente com as folhas das espécies Psychotria viridis (Rubiaceae) ou Diplopterys cabrerana (Malpighiaceae). Tradicionalmente, a confecção dessa bebida é feita com os caules da Banisteriopsis caapi, popularmente chamado de mariri, e de folhas da Psychotria viridis, conhecida como chacrona ou rainha (DOMíNGUEZ-CLAVÉ et al., 2016; ESTRELLA-PARRA et al., 2019). No âmbito da cosmologia, o cipó mariri é visto como o princípio da força masculina (mariri, o "rei da força") ao passo que as folhas constituem o princípio da força feminina (rainha, "a rainha da luz") e, a união das duas forças estabeleceria o equilíbrio, resultando nas mirações, dando suporte ao processo espiritual pela nova consciência adquirida (LABATE \& ARAÚJO, 2003).

Pelo ponto de vista farmacológico, a DMT, presente na $P$. viridis, quando ingerida de forma isolada não possui efeito subjetivo pois é rapidamente oxidada por enzimas monoamino oxidases (MAO) presentes no trato gastrointestinal. No entanto, a combinação do caule com as folhas forma uma associação sinérgica, uma vez que a $B$. caapi possui $\beta$-carbolinas como harmalina $(\mathrm{HRL})$, harmina $(\mathrm{HRM})$ e tetraidro-harmina $(\mathrm{THH})$, inibidoras reversíveis da MAO, tornando a DMT biodisponível por via oral, provocando as visões características do consumo do chá (THOMAS et al., 2013) e aumentando as concentrações de serotonina, dopamina e noradrenalina no cérebro (MCKENNA, 1998).

O mecanismo de ação da ayahuasca ainda não está totalmente elucidado. Especula-se que a combinação HRM/THH poderia ser suficiente para realizar a atividade inibitória da $M A O$, uma vez que a harmina é a $\beta$ carbolina normalmente mais abundante nas amostras de chá. A segunda $\beta$ - 
carbolina com maior concentração no chá, a THH, além de ser inibidora da MAO, também exerce efeito sobre a recaptação seletiva de serotonina (MCKENNA et al., 1998). Apesar da atividade iMAO da HRL ser a maior em comparação com as outras duas, ela é encontrada apenas em traços (SANTOS, 2007). Os alcaloides presentes na ayahuasca possuem fórmula estrutural muito semelhante à serotonina (Figura 11), logo, pode-se inferir que possuem afinidade pelos receptores serotoninérgico, dentre eles: 5$\mathrm{HT}_{1 \mathrm{~A}}$, 5-HT $2 \mathrm{~A}$ e $5-\mathrm{HT}_{2 \mathrm{C}}$. Ainda, as $\beta$-carbolinas presentes na ayahuasca atuam como agonistas serotoninérgicos indiretos, uma vez que inibem a atividade enzimática da MAO - principalmente da MAO-A (MCKENNA e RIBA, 2018).

Figura 11. Fórmula estrutural das $\beta$-carbolinas e do DMT presentes no chá da ayahuasca e do neurotransmissor serotonina.

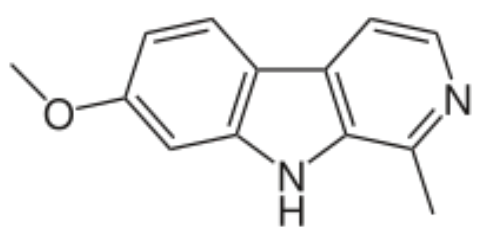

Harmina (HRM)<smiles>CN(C)CCc1c[nH]c2ccccc12</smiles>

$\mathrm{N}, \mathrm{N}$-dimetiltriptamina (DMT)

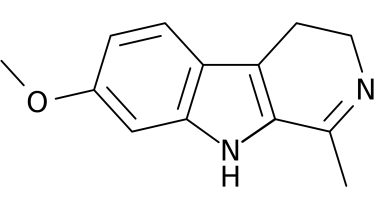

Harmalina (HRL)

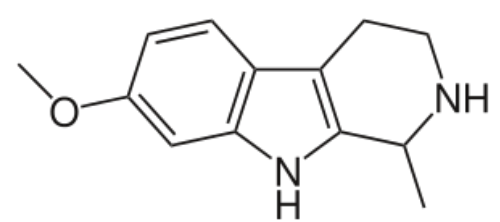

Tetrahidroharmina $(\mathrm{THH})$

Apesar do chá tradicionalmente ser constituído pelas mesmas espécies de plantas, a quantidade de DMT e das $\beta$-carbolinas variam muito entre as amostras de chá e grupos religiosos. A concentração dessas substâncias está sujeita às alterações na forma do preparo (tempo e temperatura na qual o chá é preparado), na quantidade e proporções colocadas de cada planta, lugar onde houve o plantio das espécies (efeitos de sazonalidade, época de coleta e do tipo de solo em que as espécies cresceram), as quais são variáveis importantes que modificam a 
concentração das substâncias presentes no chá do Santo Daime (MCKENNA et al., 1984).

Um estudo realizado por Callaway (2005) analisou 24 amostras proveniente de grupos religiosos distintos do Brasil, a fim de evidenciar as diferentes concentrações dos alcaloides presentes no chá distribuído durante os rituais, conforme mostrado na tabela a seguir.

Tabela 4. Concentração em $\mathrm{mg} / \mathrm{mL}$ dos alcaloides presentes em diferentes amostras do chá do Santo Daime. Dados expressos em $\mathrm{mg} / \mathrm{ml}$. UDV $(n=20)$ : DMT: $1,12 \pm 1,34 ;$ HRM: 2,25 $\pm 1,45 ;$ HRL: $0,19 \pm 0,22 ; T H H: 1,82 \pm 1,01$. Santo Daime $(n=3): D M T: 6,60 \pm 5,34 ;$ HRM: $6,84 \pm 3,46 ; \quad H R L: \quad 0,01 \pm 0,01 ; \quad T H H: 7,71 \pm 4,58$. *valores menores que 0,01 foram considerados equivalentes a zero. UDV= União do Vegetal. (Adaptado de Callaway, 2005).

\begin{tabular}{ccccc}
\hline & DMT & HRM & HRL & THH \\
\hline UDV & 0,80 & 1,72 & 0,09 & 1,83 \\
UDV & 0,66 & 0,97 & 0,08 & 2,10 \\
UDV & 0,70 & 0,87 & 0,70 & 1,74 \\
UDV & 0,87 & 2,61 & 0,10 & 1,99 \\
UDV & 0,61 & 0,98 & 0,08 & 1,79 \\
UDV & 0,83 & 2,38 & 0,08 & 1,94 \\
UDV & 0,00 & 1,58 & 0,05 & 1,27 \\
UDV & 0,77 & 0,45 & 0,04 & 1,20 \\
UDV & 0,95 & 1,58 & 0,04 & 1,23 \\
UDV & 1,05 & 3,82 & 0,08 & 1,80 \\
UDV & 2,00 & 6,25 & 0,90 & 1,49 \\
UDV & 0,36 & 3,78 & 0,28 & 5,26 \\
UDV & 3,13 & 3,36 & 0,16 & 3,11 \\
UDV & 0,38 & 1,96 & 0,23 & 1,81 \\
UDV & 0,16 & 1,39 & 0,15 & 0,49 \\
UDV & 0,20 & 1,76 & 0,21 & 0,92 \\
UDV & 0,30 & 0,96 & 0,15 & 0,48 \\
UDV & 0,25 & 1,80 & 0,30 & 1,63 \\
UDV & 2,57 & 4,89 & 0,13 & 2,78 \\
UDV & 5,84 & 1,83 & $<0,01^{*}$ & 1,47 \\
Barquinha & 12,67 & 5,58 & 0,09 & 5,42 \\
Santo Daime & 14,15 & 1,98 & $<0,01^{*}$ & 1,68 \\
Santo Daime & 2,49 & 9,80 & 0,02 & 8,65 \\
Santo Daime & 3,17 & 8,74 & 0,02 & 12,79 \\
\hline
\end{tabular}

Os efeitos da ayahuasca não são necessariamente os mesmos para todos os indivíduos. Além disso, alguns parâmetros como via de administração, a forma com a qual a DMT está apresentada, dose e set \& settings (conceito que abrange não apenas a mentalidade do indivíduo, mas 
também o ambiente físico e social no qual ocorre a exposição ao enteógeno) devem ser considerados, conforme mostra a tabela 4.

Tabela 5. Diferentes vias de administração possíveis para a ingestão do DMT.

\begin{tabular}{|c|c|c|c|c|}
\hline $\begin{array}{c}\text { Via de } \\
\text { administração }\end{array}$ & $\begin{array}{c}\text { Forma de } \\
\text { apresentação }\end{array}$ & $\begin{array}{c}\text { Dose } \\
(\mathrm{mg} / \mathrm{kg})\end{array}$ & $\begin{array}{c}\text { Início dos efeitos } \\
\text { subjetivos }\end{array}$ & $\begin{array}{c}\text { Duração dos efeitos } \\
\text { subjetivos* }^{*}\end{array}$ \\
\hline Intravenosa & DMT & $0,1-0,4$ & 5 minutos & 30 minutos \\
\hline Intramuscular & $\begin{array}{c}\text { Cloridrato ou } \\
\text { fumarato de DMT }\end{array}$ & $0,2-1$ & 2 a 5 segundos & 30 a 60 minutos \\
\hline Inalado & Freebase $^{* *}$ & $40-50 \mathrm{mg}$ & 5 minutos & $\begin{array}{c}\text { Menos de } 30 \\
\text { minutos }\end{array}$ \\
\hline Fumado & Freebase ${ }^{* *}$ & $40-50 \mathrm{mg}$ & 5 minutos & - \\
\hline Oral & Ayahuasca & $0,6-0,85^{\star * *}$ & 60 minutos & Pelo menos $4 \mathrm{~h}$ \\
\hline
\end{tabular}

Os efeitos gerados pela ingestão do chá do Santo Daime podem ser de cunho fisiológico, psicológico e transcendental. Os efeitos fisiológicos podem durar de 6 a 12 horas de acordo com o indivíduo e do ambiente o qual o ritual acontece (LABATE \& ARAÚJO, 2002). No trato gastrointestinal, incluem: náusea, vômito e diarreia; como efeitos neurológicos, tremores, tontura, midríase, sensação de formigamento e sinestesia; no sistema cardiovascular, aceleração dos batimentos cardíacos e aumento na pressão sanguínea. Alterações metabólicas como alteração da temperatura corpórea e mudança na sensitividade da pele também são observadas (RIBA et al., 2001).

Os efeitos psicológicos, por sua vez, envolvem alterações na percepção (ocorrência de visualizações' ou então, "mirações") e aumento da sensibilidade auditiva), na emoção (felicidade, tristeza, temor, espanto, medo e sentimentos de rejuvenescimento e esperança), no pensamento (os quais focam no conteúdo psicológico íntimo, podendo fornecer uma visão das preocupações pessoais, ocasionando uma nova perspectiva dos problemas) e um quadro profundo de consciência alterada, contudo sem perda de consciência. Em relação aos efeitos transcendentes, por fim, os usuários relatam visões de uma realidade espiritual, alteração de tempo e espaço, 
inatividade, insights intuitivos, experiências fora do corpo e conectividade com a natureza e universo (RIBA et al. 2001; GROB, 2002).

As visualizações recorrentes ao uso da ayahuasca possuem um padrão, no qual os itens mais comuns são cobras, jaguares, demônios, divindade, cidades e paisagens (SHANON, 2003). Secundariamente, também foram relatados casos de visões relativas à solução de crimes, voos da alma e experiências de clarividência (GROB, 2002). A ausência de miração pode ser interpretada como não merecimento espiritual do indivíduo durante o ritual. Da mesma forma, vômito e diarreia são vistos como um processo de limpeza (purge) não apenas do corpo, mas também do espírito, expurgando todas as impurezas da alma, o emocional mal resolvido e doenças físicas (LABATE, 2002; DE SOUZA, 2006).

Assim como outros alucinógenos, a ayahuasca também se mostra promissora no tratamento da farmacodependência e de comorbidades associadas à doença, como a depressão e a ansiedade (DOS SANTOS et al, 2016). Oliveira-Lima e colaboradores (2015) avaliaram o efeito da ayahuasca no desenvolvimento da sensibilização comportamental induzida pelo etanol, avaliada por meio do aumento da locomoção total em campo aberto. Os autores mostraram que nas doses de 30, 100, 200, 300 ou $500 \mathrm{mg}$ de ayahuasca/kg, houve atenuação da sensibilização comportamental ao etanol detectada pela diminuição da locomoção total em camundongos. Ainda, ela foi eficiente em bloquear a expressão da sensibilização ao etanol nas doses de 100 e de $300 \mathrm{mg}$ de ayahuasca/kg após 8 dias de tratamento (OLIVEIRALIMA et al., 2015).

Thomas et al. (2013) avaliaram o efeito combinado de quatro dias de aconselhamento em grupo liderado por especialistas com dois de cerimônias com uso de ayahuasca em participantes com fatores psicológicos e comportamentais relacionados ao uso de drogas de abuso em uma comunidade rural no Canadá. Os autores observaram que a terapia proposta levou à redução no consumo problemático de cocaína, além de diminuição do uso de etanol, tabaco e cocaína.

O grupo de pesquisa de Joselaine Ida Cruz da Universidade Federal de São Paulo realizou um estudo qualitativo com 40 usuários de crack, os quais relataram que a ayahuasca fez com que reduzissem não apenas o 
consumo de crack, como também problemas e traumas. Após o período de tratamento, apenas um pequeno número $(n=8)$ recaiu à droga (CRUZ e NAPPO, 2018).

Em tempo, embora a ayahuasca e outros alucinógenos tenham recebido grande prestígio da comunidade científica em pesquisas voltadas ao tratamento da farmacodependência desencadeada pelo uso abusivo de drogas de abuso, nenhum trabalho avaliou o possível potencial terapêutico desse alucinógeno frente as alterações desencadeadas pela dependência em cocaína a nível comportamental e molecular. 
Objetivo 


\section{Objetivo}

O objetivo deste trabalho foi avaliar o potencial da ayahuasca em prevenir a expressão da sensibilização comportamental induzida pela cocaína e as repercussões neuroquímicas do tratamento em relação aos receptores serotoninérgicos 5- $\mathrm{HT}_{1 \mathrm{~A}}$ e $5-\mathrm{HT}_{2 \mathrm{~A}}$ no córtex pré-frontal, estriado e hipocampo de camundongos C57BI/6.

Para tanto, foram empregadas as estratégias experimentais:

- Analisar a pureza da cocaína e fazer a caracterização analítica dos componentes do chá de ayahuasca por meio das técnicas CG-NPD e UPLC-ESI-MS/MS, respectivamente;

- Avaliar em campo aberto o efeito agudo de diferentes doses de ayahuasca $(1,76 ; 3,0 ; 17,6$ e $30,0 \mathrm{mg} / \mathrm{kg}$ de DMT) na atividade locomotora de camundongos;

- Realizar o protocolo de prevenção da expressão da sensibilização comportamental induzida pela cocaína com ayahuasca $(1,76 \mathrm{mg} / \mathrm{kg}$ de DMT);

- Avaliar o efeito agudo da ayahuasca (3 $\mathrm{mg} / \mathrm{kg}$ de DMT) na atividade locomotora de camundongos frente a um desafio de cocaína;

- Realizar o protocolo de prevenção à expressão da sensibilização comportamental induzida pela cocaína com ayahuasca $(3 \mathrm{mg} / \mathrm{kg}$ de DMT);

- Verificar se a ayahuasca em doses superiores (15, 30 e $45 \mathrm{mg} / \mathrm{kg}$ ) é capaz de prevenir a expressão da sensibilização comportamental induzida pela cocaína;

- Realizar o protocolo de prevenção da expressão da sensibilização comportamental induzida pela cocaína com ayahuasca $(15 \mathrm{mg} / \mathrm{kg}$ de DMT);

- Quantificar os receptores serotoninérgicos (5-HT $1 \mathrm{~A}$ e 5- $\left.\mathrm{HT}_{2 \mathrm{~A}}\right)$ nas estruturas encefálicas córtex pré-frontal, estriado e hipocampo. 
Material e Métodos 


\section{Material e Métodos}

\subsection{Animais}

Foram utilizados camundongos machos da linhagem C57BI/6 com 6 semanas de vida, provenientes do Biotério Central da Faculdade de Medicina da Universidade de São Paulo. Os animais foram acondicionados em caixas de polietileno, com acesso direto à água e comida (ração para roedores Nuvilab $\mathrm{CR} 1^{\circledR}$ ). A temperatura da sala foi mantida a $21 \pm 2^{\circ} \mathrm{C}$ e o ciclo claro (230 lux)/escuro (0 lux) de 12h, com as luzes ligadas às $7 \mathrm{~h}$. 0 projeto foi aprovado pela Comissão de Ética no Uso de Animais (CEUA) da Faculdade de Ciências Farmacêuticas da USP (CEUA/FCF 33.2016-P518).

\subsection{Drogas}

A cocaína utilizada foi adquirida pela parceria do laboratório com Instituto de Criminalística da Superintendência da Polícia Técnico-Científica (IC-SPTC) a partir da autorização judicial (Processo n 1517/17 - DIPO 5.1.1. - jms). A ayahuasca foi obtida em forma de chá $(1,5 \mathrm{~L})$ a partir de doação. A instituição ayahuasqueira optou em se manter em sigilo.

\subsection{Caracterização analítica das drogas}

\subsubsection{Avaliação do grau de pureza da cocaína por GC-MS}

\subsubsection{Preparo da amostra}

Cerca de $5 \mathrm{mg}$ da amostra de cocaína (SPTC 427210) presente no laboratório foi diluída em $5 \mathrm{~mL}$ de acetonitrila. Foram adicionados $25 \mu \mathrm{L}$ de padrão interno deuterado (cocaína- $d_{3}$ ) em $25 \mu \mathrm{L}$ da solução inicial. A solução foi homogeneizada em vórtex e em seguida, transferidas para um vial e insert e uma alíquota de $1 \mu \mathrm{L}$ foi injetada no GC-MS.

\subsubsection{Preparo da amostra}

O sistema de GC-MS consiste em um cromatógrafo gasoso (6850 Network GC System) Agilent Technologies (Califórnia, EUA) equipado com um forno para coluna, um injetor automático, controlados por um módulo de 
comunicação e pelo software MSD ChemStation E.02.01.1177. O sistema é integrado a um espectrômetro de massas do tipo quadrupolo modelo 5875 Series MSD (Agilent Technologies). A análise cromatográfica foi realizada em uma coluna capilar de sílica fundida HP-5MS (30m x 0,25 $\mu \mathrm{m}$ de diâmetro $\mathrm{x}$ $0,1 \mu \mathrm{m}$ de filme, Agilent Technologies J\&W GC Columns, EUA). A injeção foi feita em modo splitless, utilizando hélio como gás de arraste em fluxo constante de 0,6 mL/min. A temperatura do injetor foi de $200^{\circ} \mathrm{C}$ e a temperatura da linha de transferência e do detector $280^{\circ} \mathrm{C}$. As condições do forno foram $100^{\circ} \mathrm{C}(1 \mathrm{~min}), 10^{\circ} \mathrm{C} / \mathrm{min}$ até $300^{\circ} \mathrm{C}(4 \mathrm{~min})$, sendo o tempo total de corrida de $25 \mathrm{~min}$. A análise realizada do espectrômetro de massas foi ionização por elétrons no modo positivo. A temperatura da fonte de ionização foi de $230^{\circ} \mathrm{C}$. O modo de operação foi SIM (selected ion monitoring) com monitoramento dos seguintes fragmentos de massas, como mostrado na Tabela 6.

Tabela 6. Descrição dos fragmentos $(\mathrm{m} / \mathrm{z})$ monitorados no método por GC-MS.

\begin{tabular}{cc}
\hline Analito & Fragmento $(\mathrm{m} / \mathrm{z})$ \\
\hline \multirow{2}{*}{ Cocaína } & 82 \\
& 182 \\
& 303 \\
\hline \multirow{2}{*}{ Cocaína-d3 } & 85 \\
& 185 \\
& 306 \\
\hline
\end{tabular}

\subsubsection{Dosagem de cocaína e benzoilecgonina em amostras de plasma de camundongo por UPLC-ESI-MS/MS}

\subsubsection{Coleta das amostras}

Para realizar a coleta de sangue periférico, os animais foram anestesiados com cetamina e xilazina (2:1) i.p. de acordo com o peso e as amostras de sangue foram transferidas para microtubos contendo heparina (1 $\mathrm{U} / \mathrm{mL}$ ). O sangue foi centrifugado (Centrifuge 5810R, Eppendorf) a 10.000 rpm durante 5 minutos e o plasma foi coletado em microtubos contendo 
fluoreto de sódio $2 \%$. Os plasmas foram congelados a $-80^{\circ} \mathrm{C}$ e armazenados até o dia das análises.

\subsubsection{Preparo das amostras}

Ao plasma foram adicionados $20 \mu \mathrm{L}$ de padrão interno deuterado (cocaína- $\mathrm{d}_{3}$ e benzoilecgonina- $\mathrm{d}_{3} ; 500 \mathrm{ng} / \mathrm{mL}$ ) em $100 \mu \mathrm{L}$ de plasma. Em seguida foram adicionados $880 \mu \mathrm{L}$ de uma solução de acetonitrila/metanol (80:20). A mistura foi então homogeneizada em vórtex e em seguida centrifugada (Centrifuge 5810R, Eppendorf) a 9.000 rpm por 6 minutos. Em seguida, foram transferidos $100 \mu \mathrm{L}$ do sobrenadante para um vial e insert e uma alíquota de $3 \mu \mathrm{L}$ foi injetada no LC-MS/MS.

\subsubsection{Condições cromatográficas}

O sistema de LC-MS/MS consiste em um UPLC série Acquity (Waters, EUA) equipado com uma bomba quaternária, um forno para coluna, um injetor automático, controlados por um módulo de comunicação e pelo software MassLynx V4.1. O sistema é integrado a um espectrômetro de massas triplo quadrupolo modelo Quattro Premier XE (Micromass, Reino Unido). As análises foram realizadas em modo positivo $(E S I+,[M+H]+)$ utilizando os seguintes parâmetros de fonte: desolvation gas, $1100 \mathrm{~L} / \mathrm{h}$; cone gas, $100 \mathrm{~L} / \mathrm{h}$; desolvation temp, $350^{\circ} \mathrm{C}$; source temp, $120^{\circ} \mathrm{C}$; capillary $3 \mathrm{KV}$. A eluição cromatográfica foi realizada em uma coluna Acquicty UPLC BEH C18 2,1 x 100 mm, 1,7 um (Waters, EUA), eluída com um gradiente de tampão formiato de amônio $1 \mathrm{mM}$ em água (Solução A) e tampão formiato de amônio em acetonitrila e água (95:5, v/v; Solução B), ambas soluções suplementadas com $0,1 \%$ de ácido fórmico, a um fluxo de $400 \mu \mathrm{L} / \mathrm{min}, 40^{\circ} \mathrm{C}(0-3$ minutos, $10-45 \%$ de B; 3 - 3,8 minutos, $45-80 \%$ de B; 3,8 - 4 minutos, $80-10 \%$ de B; 4 - 7 minutos, 10\% de B). O tempo total de corrida foi de 7 minutos, as fragmentações utilizadas no MRM estão descritas na Tabela 7. 
Tabela 7. Descrição do íon precursor (Q1; $\mathrm{m} / \mathrm{z})$, íon produto (Q3; $\mathrm{m} / \mathrm{z}$ ), energia no cone e energia de colisão, utilizadas no método por UPLC-ESI-MS/MS.

\begin{tabular}{|c|c|c|c|c|}
\hline Analito & Q1 (m/z) & Q3 (m/z) & $\begin{array}{c}\text { Voltagem do } \\
\text { cone }(\mathrm{V})\end{array}$ & $\begin{array}{l}\text { Energia de } \\
\text { colisão }(\mathrm{eV})\end{array}$ \\
\hline & & 181,81 & & 20 \\
\hline \multirow[t]{3}{*}{ Cocaína } & 304,30 & 104,68 & 35 & 50 \\
\hline & & 81,79 & & 50 \\
\hline & & 184,91 & & 19 \\
\hline \multirow[t]{3}{*}{ Cocaína-d3 } & 307,12 & 104,76 & 35 & 35 \\
\hline & & 84,78 & & 31 \\
\hline & & 167,90 & & 21 \\
\hline \multirow[t]{3}{*}{ Benzoilecgonina } & 290,16 & 104,78 & 30 & 31 \\
\hline & & 76,80 & & 47 \\
\hline & & 170,64 & & 19 \\
\hline \multirow[t]{2}{*}{ Benzoilecgonina-d3 } & 293,23 & 104,66 & 35 & 29 \\
\hline & & 85,06 & & 31 \\
\hline
\end{tabular}

\subsubsection{Dosagem dos alcaloides da ayahuasca em amostra de chá por UPLC-ESI-MS/MS}

\subsubsection{Liofilização da ayahuasca}

O método apresentado para liofilização do chá de ayahuasca foi indicado pelo Dr. Rodney Alexandre Rodrigues, coordenador da divisão de química de produtos naturais do Centro Pluridisciplinar de Pesquisas Químicas, Biológicas e Agrícolas da Universidade Estadual de Campinas (CPQBA-Unicamp). A amostra de ayahuasca foi liofilizada por aproximadamente 4 dias utilizando os seguintes parâmetros de pressão e temperatura: $500 \mu \mathrm{Hg} \mathrm{e}-53^{\circ} \mathrm{C}$.

\subsubsection{Preparo da amostra}

A amostra de chá liofilizada foi diluída na fase móvel em uma proporção final de 1:5000 por diluição seriada em três etapas $(1: 10 \times 1: 10 \times$ 1:50). Primeiro diluiu-se $100 \mu \mathrm{L}$ da alíquota de chá em $900 \mu \mathrm{L}$ de fase móvel A (tampão formiato de amônio com $0,1 \%$ ácido fórmico). Desta, foram retirados mais $100 \mu \mathrm{L}$ e diluídos com $900 \mu \mathrm{L}$ de fase móvel A e, finalmente, 
$100 \mu \mathrm{L}$ da última foi diluído em $4900 \mu \mathrm{L}$ da solução de fase móvel $\mathrm{A}$. A cada etapa de diluição a solução era submetida a agitação em vórtex para melhor homogeneização. Em $90 \mu \mathrm{L}$ da solução final adicionaram-se $10 \mu \mathrm{L}$ do padrão

interno (DMT- $d_{6} 1 \mu \mathrm{g} / \mathrm{mL}$ ) para concentração final de $100 \mathrm{ng} / \mathrm{mL}$. Por fim, 5 $\mu \mathrm{L}$ desta solução foram injetados no sistema de UPLC-ESI-MS/MS. Após quantificação, o valor obtido com a equação da reta foi multiplicado por 5000 para correção da diluição.

\subsubsection{Condições cromatográficas}

As análises foram realizadas por LC-MS/MS em modo positivo (ESI+, $[\mathrm{M}+\mathrm{H}]^{+}$) para todos os analitos. Foram utilizados os seguintes parâmetros otimizados: cone gas flow, $2 \mathrm{~L} / \mathrm{min}$; desolvation gas flow, $10 \mathrm{~L} / \mathrm{min}$; source temperature, $100{ }^{\circ} \mathrm{C}$; desolvation temperature, $350{ }^{\circ} \mathrm{C}$. O seguinte sistema cromatográfico foi utilizado: Coluna Acquity UPLC BEH C18 2,1 mm x 100 $\mathrm{mm}$, ID 1,7 $\mu \mathrm{m}$ (Waters Corporation, Milford, MA) eluída com um gradiente de tampão formiato de amônio $2 \mathrm{mM}$ com $0,1 \%$ de ácido fórmico (Solução $\mathrm{A}$ ) e metanol $0,1 \%$ ácido fórmico (Solução B), a um fluxo de $300 \mu \mathrm{L} / \mathrm{min}, 40{ }^{\circ} \mathrm{C}$, nas seguintes condições: 0 - 7 minutos, 90 - 50 \% A; 7,1 - 8 minutos, 50 - 90 $\%$ B. O tempo total de corrida foi de 8 minutos. As fragmentações utilizadas no MRM e os tempos de retenção de cada analito estão descritas na Tabela 8. 
Tabela 8. Descrição dos íons precursores, íons produto, tempo de retenção, voltagem do cone e energia de colisão no método por UPLC-ESI-MS/MS.

\begin{tabular}{cccccc}
\hline Analito & $\begin{array}{c}\text { Tempo de } \\
\text { Retenção } \\
(\mathrm{min})\end{array}$ & $\begin{array}{c}\text { Íon } \\
\text { precusor }(\mathrm{m} / \mathrm{z})\end{array}$ & $\begin{array}{c}\text { Íon produto } \\
(\mathrm{m} / \mathrm{z})\end{array}$ & $\begin{array}{c}\text { Voltagem } \\
\text { do cone }(\mathrm{V})\end{array}$ & $\begin{array}{c}\text { Energia } \\
\text { de colisão } \\
(\mathrm{eV})\end{array}$ \\
\hline \multirow{2}{*}{$\begin{array}{c}\text { DMT-d6 } \\
\text { (PI) }\end{array}$} & 2,87 & 195,1 & 63,9 & 15 & 14 \\
& & 195,1 & 114,9 & 15 & 36 \\
DMT & 195,1 & $143,8^{*}$ & 15 & 22 \\
& 2,88 & 188,9 & 57,8 & 25 & 11 \\
& & 188,9 & 116,7 & 25 & 29 \\
THH & 188,9 & $143,8^{*}$ & 25 & 17 \\
& 4,37 & 217,1 & 172,8 & 25 & 29 \\
HRL & & 217,1 & 187,9 & 25 & 17 \\
& & 217,1 & $200,0^{*}$ & 25 & 13 \\
& 5,27 & 215,2 & 130,4 & 50 & 41 \\
HRM & 215,2 & 171,7 & 50 & 33 \\
& & 215,2 & $199,9^{*}$ & 50 & 25 \\
& 5,56 & 213,2 & 143,8 & 50 & 41 \\
\hline
\end{tabular}

*Transição utilizada para quantificação dos analitos. PI - padrão interno. $\mathrm{m} / \mathrm{z}$ - razão massa/carga. 


\subsection{Análise comportamental}

\subsubsection{Análise da atividade locomotora no Campo Aberto}

A atividade locomotora total $(\mathrm{cm})$ dos animais foi avaliada pela manhã durante todos os dias experimentais com auxílio da câmera Intelbras HDCVI com infravermelho e quantificada pelo programa EthoVision ${ }^{\circledR} \mathrm{XT} \quad 11.5$ (Noldus). O aparato de campo aberto (CA) utilizado consiste em uma arena circular de acrílico com $40 \mathrm{~cm}$ de diâmetro e $60 \mathrm{~cm}$ de altura (BROADHURST, 1960).

Após a avaliação da atividade locomotora de cada animal, o CA foi higienizado com uma solução alcoólica $5 \%$ antes da introdução do próximo animal, para evitar possíveis rastros de odor deixados pelo anterior.

\subsubsection{Análise comportamental no Labirinto em Cruz Elevado}

O teste em labirinto em cruz elevado (LCE) avalia os efeitos ansiolíticos de uma dada substância, sendo assim é possível também inferir o grau de ansiedade dos animais, sintoma característico da síndrome de abstinência. O LCE consiste em dois braços abertos $(30 \times 5 \times 0,25 \mathrm{~cm})$ e dois braços fechados de mesmo tamanho, porém, com paredes de $20 \mathrm{~cm}$ de altura. Os braços similares são cruzados em ângulo reto, conectados por uma área central além disso, o aparelho é posicionado a $60 \mathrm{~cm}$ do chão.

Os animais foram colocados individual e gentilmente no centro do labirinto, sendo que os animais foram avaliados por 5 minutos por meio do número de entradas e tempo de permanência nos braços abertos e fechados (PELLOW et al., 1985).

\subsubsection{Delineamento experimental}

\subsubsection{Avaliação do efeito agudo da ayahuasca na atividade locomotora de camundongos em campo aberto}

A fim de verificar a influência da ayahuasca na atividade locomotora de camundongos, 30 animais foram inicialmente submetidos à $1 \mathrm{~h}$ de habituação no CA logo após receberem, por gavagem, água filtrada durante dois dias consecutivos. 
No terceiro dia, os animais foram divididos em cinco grupos: água filtrada; 1,76; 3,0; 17,6 e 30,0 mg/kg de DMT. Após receberem a dose equivalente ao grupo, a atividade locomotora dos animais foi avaliada por $1 \mathrm{~h}$ no CA. O delineamento do protocolo experimental proposto está apresentado na Figura 12.

Figura 12. Delineamento experimental para avaliação do perfil de atividade locomotora de camundongos machos C57BI/6 frente a diferentes doses agudas de ayahuasca. O protocolo contempla dois dias consecutivos de habituação no aparato de campo aberto (CA) e um dia de administração de ayahuasca por gavagem nas doses 0; 1,76; 3,0;17,6; 30,0 mg/kg de DMT. Em todos os dias experimentais a atividade locomotora dos animais foi avaliada por sessenta minutos no aparato de CA.

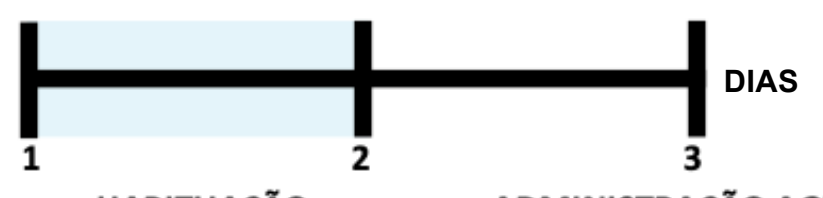

\section{HABITUAÇÃO}

2 dias consecutivos água filtrada v.o. $60^{\prime} \mathrm{CA}$

\section{ADMINISTRAÇÃO AGUDA}

água filtrada v.o.

AYA $(1,76 ; 3 ; 17,6 ; 30 \mathrm{mg} / \mathrm{kg}$ de DMT) v.o.

$60^{\prime} \mathrm{CA}$

\subsubsection{Avaliação do efeito agudo da ayahuasca $(3 \mathrm{mg} / \mathrm{kg}$ de DMT) na atividade locomotora de camundongos em resposta à cocaína}

Visando avaliar o efeito agudo da ayahuasca na dose de $3 \mathrm{mg} / \mathrm{kg}$ de DMT como possível fator protetor sob os efeitos psicoestimulantes da cocaína na atividade locomotora de camundongos posteriormente tratados com cocaína, realizou-se um estudo no qual os camundongos foram divididos em dois grupos: grupo controle, tratado com água filtrada v.o.; e grupo ayahuasca (3 mg/kg de DMT v.o.). Imediatamente após a administração das substâncias, os animais foram submetidos ao CA, onde permaneceram por meia hora.

Logo após o término dessa avaliação, metade dos animais de cada grupo recebeu salina $0,9 \%$ i.p. ou cocaína $10 \mathrm{mg} / \mathrm{kg}$, i.p., formando os grupos Controle-Controle, Ayahuasca-Controle, Controle-Cocaína e AyahuascaCocaína, a saber: 
- Controle-Controle: animais que na primeira meia hora do experimento receberam água filtrada v.o. e, na segunda meia hora do experimento receberam salina $0,9 \%$ i.p.;

- Controle-Cocaína: animais que na primeira meia hora do experimento receberam água filtrada v.o. e, na segunda meia hora do experimento receberam cocaína $10 \mathrm{mg} / \mathrm{kg}$ i.p.;

- Ayahuasca-Controle: animais que na primeira meia hora do experimento receberam ayahuasca $3 \mathrm{mg} / \mathrm{kg}$ de DMT v.o. e, na segunda meia hora do experimento receberam salina $0,9 \%$ i.p.;

- Ayahuasca-Cocaína: animais que na primeira meia hora do experimento receberam ayahuasca $3 \mathrm{mg} / \mathrm{kg}$ de DMT v.o. e, na segunda meia hora do experimento receberam cocaína $10 \mathrm{mg} / \mathrm{kg}$ i.p..

Após a administração da segunda substância, os camundongos permaneceram por mais meia hora no CA para que a atividade locomotora deles fosse mensurada. A Figura 13 apresenta o delineamento do protocolo experimental proposto.

Figura 13. Delineamento experimental utilizado para avaliar o efeito da ayahuasca anterior ao desafio com cocaína $10 \mathrm{mg} / \mathrm{kg}$ i.p. na atividade locomotora de camundongos machos C57BI/6. Inicialmente, metade dos camundongos receberam água filtrada v.o. $(n=14)$ e a outra metade, ayahuasca $3 \mathrm{mg} / \mathrm{kg}$ de DMT v.o. $(n=14)$. Após trinta minutos de avaliação da atividade locomotora no aparato de campo aberto, metade dos animais que receberam água filtrada, receberam salina $0,9 \%$ i.p. ( $n=7$ ), ao passo que os outros camundongos receberam cocaína $10 \mathrm{mg} / \mathrm{kg}$ i.p. Metade dos camundongos que no início do experimento receberam ayahuasca na dose de $3 \mathrm{mg} / \mathrm{kg}$ de DMT receberam salina 0,9\% i.p. $(n=7)$ e o restante dos camundongos recebeu cocaína 10mg/kg i.p. $(n=7)$.

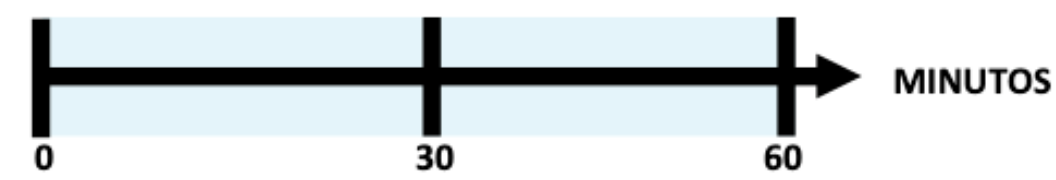

AYAHUASCA

água filtrada v.o.

COCAÍNA

salina $0,9 \%$ i.p.

AYA (3 mg/kg de DMT) v.o. COC $10 \mathrm{mg} / \mathrm{kg}$ i.p. 


\subsubsection{Efeito da ayahuasca na prevenção da expressão da sensibilização comportamental à cocaína}

\subsection{Protocolo I - ayahuasca na dose de $1,76 \mathrm{mg} / \mathrm{kg}$ de DMT/kg}

Inicialmente, os animais foram habituados por 2 dias consecutivos no aparato de CA durante 10 minutos após receberem injeção de salina 0,9\% i.p.. Vinte e quatro horas após o segundo dia de habituação, iniciou-se o protocolo de sensibilização comportamental induzida pela cocaína, quando os animais foram tratados com salina 0,9\% i.p. ou cocaína $10 \mathrm{mg} / \mathrm{kg}$ i.p. (MARINHO et al., 2017) durante 10 dias, em dias alternados (do $3^{\circ}$ ao $11^{\circ}$ dia) e expostos ao CA por 10 minutos. No $11^{\circ}$ dia, após o teste comportamental do CA, aproximadamente $200 \mu \mathrm{L}$ de sangue da cauda foram coletados de cada animal para dosagem de cocaína por UPLC-ESI-MS/MS.

No dia seguinte $\left(12^{\circ} \mathrm{dia}\right)$, iniciou-se o período de tratamento, no qual os animais receberam, por gavagem, água filtrada ou ayahuasca na dose de $1,76 \mathrm{mg} / \mathrm{kg}$ de DMT por dia, a qual representa uma dose eficaz para tratar pacientes em quadro depressivo (SAMPEDRO et al., 2017). Após administração, os animais retornaram para suas respectivas gaiolas moradias e após 30 minutos, foram expostos ao CA por 10 minutos. Esse intervalo entre a administração da ayahuasca e a análise comportamental é necessário pois há estudos mostrando que drogas alucinógenas podem apresentar um perfil de locomoção bifásico, com a hiperlocomoção induzida por elas observada apenas nos períodos de pós-tratamento mais longos (MITTMAN \& GEYER, 1991; HALBERSTADT et al., 2012). O período de tratamento durou oito dias consecutivos (do $12^{\circ}$ ao $19^{\circ} \mathrm{dia}$ ).

No $18^{\circ}$ dia à tarde, foi realizado o teste de LCE, o qual foi realizado no $7^{\circ}$ dia de tratamento com ayahuasca para que não houvesse possíveis interferências nas análises neuroquímicas realizadas após eutanásia, uma vez que o teste pode induzir alteração na concentração proteica de algumas proteínas devido à aprendizagem e exploração de um novo ambiente.

No $20^{\circ}$ dia, os animais foram desafiados com uma nova administração de salina $0,9 \%$ ou cocaína $10 \mathrm{mg} / \mathrm{kg}$ (i.p), seguido da análise comportamental no CA. Após o desafio ( $\left.20^{\circ} \mathrm{dia}\right)$, os animais foram submetidos à eutanásia 
por decapitação e o sangue foi coletado para dosagem de cocaína por LCMS/MS.

A Figura 14 apresenta o delineamento do protocolo experimental proposto.

Figura 14. Delineamento experimental do protocolo de prevenção da expressão da sensibilização comportamental induzida pela cocaína, utilizando ayahuasca $(1,76 \mathrm{mg} / \mathrm{kg}$ de DMT). Camundongos machos C57BI/6 foram habituados durante 2 dias consecutivos $\left(1^{\circ}\right.$ ao $2^{\circ}$ dia) ao campo aberto (CA) após administração de salina 0,9\% i.p. No dia seguinte ( $3^{\circ}$ dia), iniciou-se o protocolo de sensibilização comportamental, e os animais receberam cocaína 10 $\mathrm{mg} / \mathrm{kg}$ ou salina $0,9 \%$ i.p. por 10 dias, em dias alternados $\left(3^{\circ}\right.$ ao $11^{\circ}$ dia) e expostos ao CA. Vinte e quatro horas depois, os animais receberam ayahuasca $(1,76 \mathrm{mg} / \mathrm{kg}$ de DMT) ou água filtrada v.o. durante 8 dias consecutivos $\left(12^{\circ}\right.$ ao $19^{\circ}$ dia) e, após 30 minutos, foram submetidos ao CA. No $20^{\circ}$ dia, os animais foram desafiados com cocaína $10 \mathrm{mg} / \mathrm{kg}$ e foram imediatamente expostos ao CA. Após a última avaliação da atividade locomotora em $C A$, os animais foram eutanasiados por decapitação $\left({ }^{*}\right)$. Em todos os dias de manipulação, os animais foram expostos ao CA por 10 minutos. No $18^{\circ}$ experimental, à tarde, foi realizada avaliação no labirinto em cruz elevado (LCE). Nos dias 11 e 20, foi coletado sangue, via cauda,I para a dosagem de cocaína e benzoilecgonina por UPLC-ESI-MS/MS (\#).

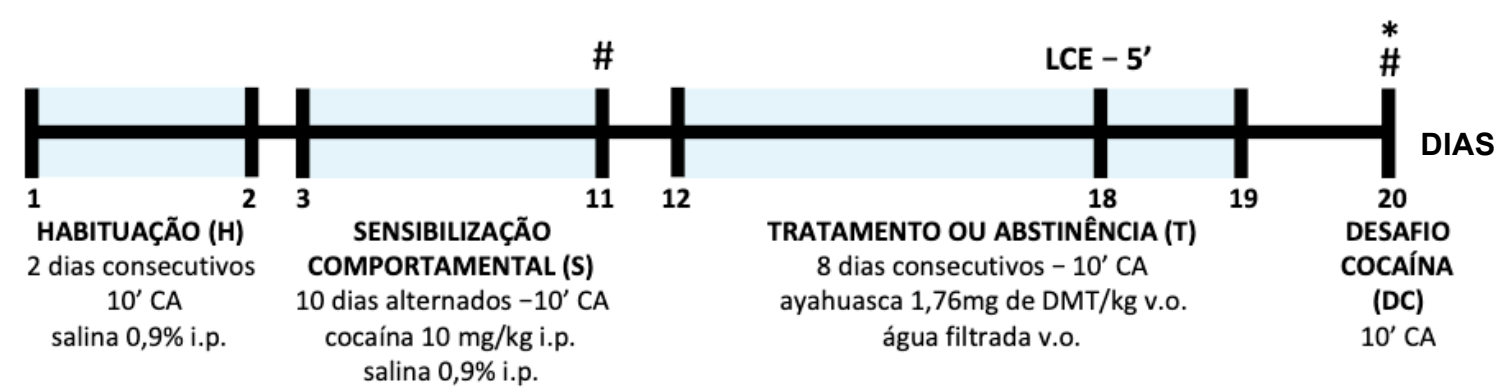

\subsection{Protocolo II - ayahuasca nas doses de 3, 15, 30 e $45 \mathrm{mg} / \mathrm{kg}$ de DMT}

Inicialmente os animais foram habituados $(H)$ por 3 dias consecutivos (H1-H3) no aparato de CA durante 30 minutos, após uma injeção de salina $0,9 \%$ i.p. Vinte e quatro horas após o terceiro dia de habituação, iniciou-se o protocolo de sensibilização comportamental induzida pela cocaína (S), quando os animais foram tratados com salina 0,9\% i.p. ou cocaína $10 \mathrm{mg} / \mathrm{kg}$ i.p. (MARINHO et al., 2017) durante 10 dias alternados (do $4^{\circ}$ ao $12^{\circ}$ dia, S1S5) e expostos ao CA por 30 minutos.

No dia seguinte $\left(13^{\circ} \mathrm{dia}\right)$, iniciou-se o protocolo de tratamento, no qual os animais receberam, por gavagem, água filtrada ou ayahuasca nas doses de 3,15, 30 e $45 \mathrm{mg} / \mathrm{kg}$ de DMT. Após cada administração, os animais retornaram para suas respectivas gaiolas moradias e após 30 minutos, foram 
expostos ao CA por 30 minutos. O período de tratamento $(\mathrm{T})$ durou oito dias consecutivos (do $13^{\circ}$ ao $20^{\circ}$ dia, T1-T8).

No $21^{\circ}$ dia, todos os animais foram desafiados com salina $0,9 \%$ i.p. e foram imediatamente expostos ao CA por 30 minutos. No dia seguinte $\left(22^{\circ}\right.$ dia), todos os animais foram desafiados com cocaína $10 \mathrm{mg} / \mathrm{kg}$ i.p. seguido da análise comportamental no CA. Após o desafio cocaína, os animais foram eutanasiados por decapitação e o córtex pré-frontal, estriado e hipocampo dissecadas para futura análise por immunoblotting dos receptores serotoninérgicos (5- $\mathrm{HT}_{1 \mathrm{~A}} \mathrm{R}$ e $\left.5-\mathrm{HT}_{2 \mathrm{~A}} \mathrm{R}\right)$.

A Figura 15 apresenta o delineamento do protocolo experimental proposto.

Figura 15. Delineamento experimental do protocolo de prevenção da expressão da sensibilização comportamental induzida pela cocaína, utilizando ayahuasca $(3,15,30$ e 45 $\mathrm{mg} / \mathrm{kg}$ de DMT). Camundongos machos C57Bl/6 foram habituados por 3 dias consecutivos $\left(1^{\circ}\right.$ ao $3^{\circ}$ dia) ao campo aberto (CA), logo após administração de salina 0,9\%. No dia seguinte, iniciou-se o protocolo de sensibilização comportamental, e os animais receberam cocaína $10 \mathrm{mg} / \mathrm{kg}$ ou salina $0,9 \%$ i.p. por 10 dias, em dias alternados $\left(3^{\circ}\right.$ ao $11^{\circ}$ dia) e expostos ao CA. Vinte e quatro horas depois, os animais receberam ayahuasca $(3,15,30$ e $45 \mathrm{mg} / \mathrm{kg}$ de DMT) ou água filtrada v.o. por oito dias consecutivos $\left(14^{\circ}\right.$ ao $20^{\circ}$ dia). No $21^{\circ}$ dia, os camundongos foram desafiados com salina 0,9\% i.p. e, no dia seguinte, foram desafiados com cocaína $10 \mathrm{mg} / \mathrm{kg}$ i.p. Em todos os dias de manipulação, a atividade locomotora dos animais foi avaliada em CA por 30 minutos. No último dia experimental, logo após a exposição dos animais ao CA, os camundongos foram eutanasiados (*) por decapitação.

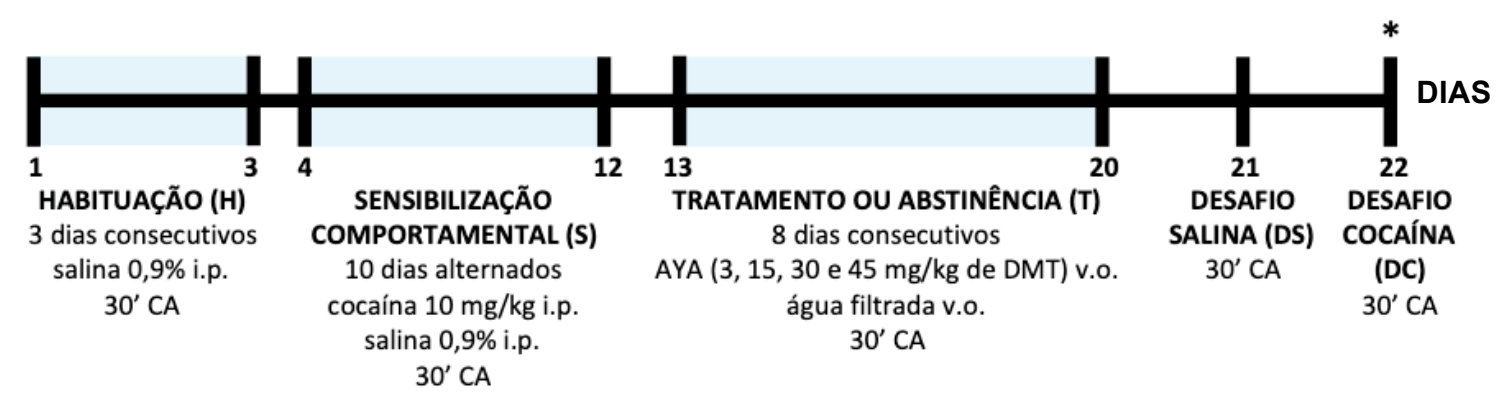

Ao término dos protocolos I e II, os seguintes grupos experimentais foram formados, alterando apenas a dose de ayahuasca entre eles.

- Salina-Salina-Salina (SSS): animais que foram sensibilizados com salina, tratados com água filtrada e desafiados com cocaína;

- Salina-Salina-Cocaína (SSC): animais que foram sensibilizados com salina, tratados com água filtrada e desafiados com cocaína; 
- Salina-Ayahuasca-Salina (SAS): animais que foram sensibilizados com salina, tratados com ayahuasca e desafiados com cocaína;

- Salina-Ayahuasca-Cocaína (SAC): animais que foram sensibilizados com salina, tratados com ayahuasca e desafiados com cocaína;

- Cocaína-Salina-Cocaína (CSS): animais que foram sensibilizados com cocaína, tratados com água filtrada e desafiados com cocaína;

- Cocaína-Salina-Cocaína (CSC): animais que foram sensibilizados com cocaína, tratados com água filtrada e desafiados com cocaína;

- Cocaína-Ayahuasca-Salina (CAS): animais que foram sensibilizados com cocaína, tratados com ayahuasca e desafiados com salina;

- Cocaína-Ayahuasca-Cocaína (CAC): animais que foram sensibilizados com cocaína, tratados com ayahuasca e desafiados com cocaína.

\subsubsection{Análise estatística}

ANOVA de duas vias com medidas repetidas e post-hoc de Bonferroni foi emprega ao comparar a atividade locomotora dos grupos num período experimental. E, ANOVA de uma via com medidas repetidas e post-hoc de Bonferroni foi realizada para comparação da atividade locomotora entre os grupos num mesmo dia experimental. E, quando necessário, para foi realizado test-t de Student para amostras não pareadas. 


\subsection{Análise proteica por immunoblotting}

A técnica de immunoblotting foi utilizada para a quantificação dos receptores serotoninérgicos $\left(5-\mathrm{HT}_{1 \mathrm{~A}} \mathrm{R}\right.$ e $\left.5-\mathrm{HT}_{2 \mathrm{~A}} \mathrm{R}\right)$ nas regiões encefálicas alvo: córtex pré-frontal, estriado e hipocampo.

\subsubsection{Coleta as amostras}

Imediatamente após a exposição ao CA (30 minutos após a administração de cocaína no último dia experimental), os animais foram eutanasiados por decapitação, os encéfalos foram retirados e dissecados para remoção das estruturas de interesse: córtex pré-frontal, estriado e hipocampo.

Esse processo ocorreu sobre gelo e cada estrutura foi armazenada em microtubos e congelada com gelo seco e armazenadas a $-80^{\circ} \mathrm{C}$ até o dia da análise.

\subsubsection{Preparo das amostras}

As amostras de tecido armazenadas foram homogeneizadas com tampão Tris-HCl 50 mM pH 7,4 contendo PMSF 1 mM e coquetel inibidor de protease 1:1000. Para todas as estruturas foi utilizada a diluição $1: 5(\mathrm{~g} / \mathrm{mL})$. Em seguida, as estruturas foram sonicadas e, para ajuste da quantidade de proteína a ser aplicada, realizou-se a quantificação das proteínas totais pelo método de Bradford (1976) e posterior diluição dos homogenatos com os tempões Tris-HCl 50 mM pH 7,4 e Laemmli $(0,0625 \mathrm{M}$ de Tris- $\mathrm{HCl}$, pH 6,8 contendo $2 \%$ de SDS, $10 \%$ de glicerol, $0,001 \%$ de azul de bromofenol e $5 \%$ de 2-mercaptoetanol). Para as 3 estruturas, padronizou-se a concentração proteica de $2,5 \mu \mathrm{g} / \mu \mathrm{L}$.

\subsubsection{Método de immunoblotting}

Primeiramente, as amostras foram submetidas à eletroforese por SDSPAGE, em gel de poliacrilamida $15 \%$, onde as proteínas migraram durante 170 minutos, sob diferença de potencial elétrico de $90 \mathrm{~V}$ nos primeiros 10 minutos, e $100 \mathrm{~V}$ no restante do tempo. Após a separação eletroforética, as proteínas foram transferidas para uma membrana de PVDF (Millipore, 0,45 
$\mu \mathrm{m}$ de diâmetro) sob amperagem constante de 0,4 A durante 90 minutos. A transferência foi confirmada pela coloração das membranas com o corante vermelho de Ponceau e lavadas com água destilada. Prosseguiu-se então com a incubação das membranas com solução bloqueadora (leite desnatado Molico, Nestlé, 5\% em tampão Tris-Salina com Tween 20 - TBS-T) por 60 minutos, a fim de saturar sítios de ligação inespecíficos. Após 6 ciclos de lavagem de 5 minutos com TBS-T, os antígenos presentes nas membranas foram submetidos à caracterização imunoenzimática. As membranas foram incubadas overnight a $4^{\circ} \mathrm{C}$ com anticorpos primários específicos diluídos em TBS-T. A Tabela 9 apresenta os dados dos anticorpos utilizados.

No dia seguinte, as membranas foram novamente lavadas 6 vezes por 5 minutos com TBS-T e incubadas por $2 \mathrm{~h}$, à temperatura ambiente e protegidas da luz, com anticorpo secundário marcado com peroxidase (antirabbit, 1:3000 - Santa Cruz Biotechnology). O excesso de conjugado foi removido com mais um ciclo de lavagens, analogamente ao do anticorpo primário, e os antígenos revelados com o kit de detecção quimoluminescente ECL Western Blotting Detection Reagents (GE HeathcareBio-Sciences AB, Uppsala, Suécia). As imagens foram detectadas (Amersham Imager 600, GE Healthcare) e digitalizadas (IQuantCapture 400, v.1.0.0, GE Healthcare). As intensidades das bandas imunorreativas foram comparadas pelo programa ImageQuant 400 (GE Healthcare) e expressas em unidades arbitrárias. A $\beta$ actina (controle interno; 1:10000) foi utilizada como fator normalizador.

Tabela 9. Características dos anticorpos primários utilizados nos experimentos propostos para immunoblotting.

\begin{tabular}{lcccc}
\hline Proteína & Fabricante & Código & Peso Molecular (kDa) & Diluição \\
\hline 5- $\mathrm{HT}_{1 \mathrm{~A}} \mathrm{R}$ & Abcam & ab64994 & 46 & $1: 1000$ \\
$5-\mathrm{HT}_{2 \mathrm{~A}} \mathrm{R}$ & Abcam & ab66049 & 53 & $1: 1000$ \\
\hline
\end{tabular}

\subsubsection{Análise estatística}

Foi empregada ANOVA de uma via com medidas repetidas e post-hoc de Bonferroni para fins comparativos. 
Resultados 


\section{Resultados}

\subsection{Caracterização analítica das drogas}

\subsubsection{Avaliação do grau de pureza da cocaína por GC-MS}

A Figura 16 apresenta o cromatograma relativo à análise da pureza do pó de cocaína presente no laboratório e a Figura 17 apresenta os fragmentos $(82,182,303)$ monitorados durante a corrida. Como resultado, obtivemos $89 \%$ de pureza.

Figura 16. Cromatograma obtido pela análise da cocaína presente no laboratório. Em preto, a amostra de cocaína analisada e, em azul, o padrão interno deuterado (cocaína- $d_{3}$ ) adicionado à amostra. A avaliação da pureza da cocaína se deu por GC-MS.

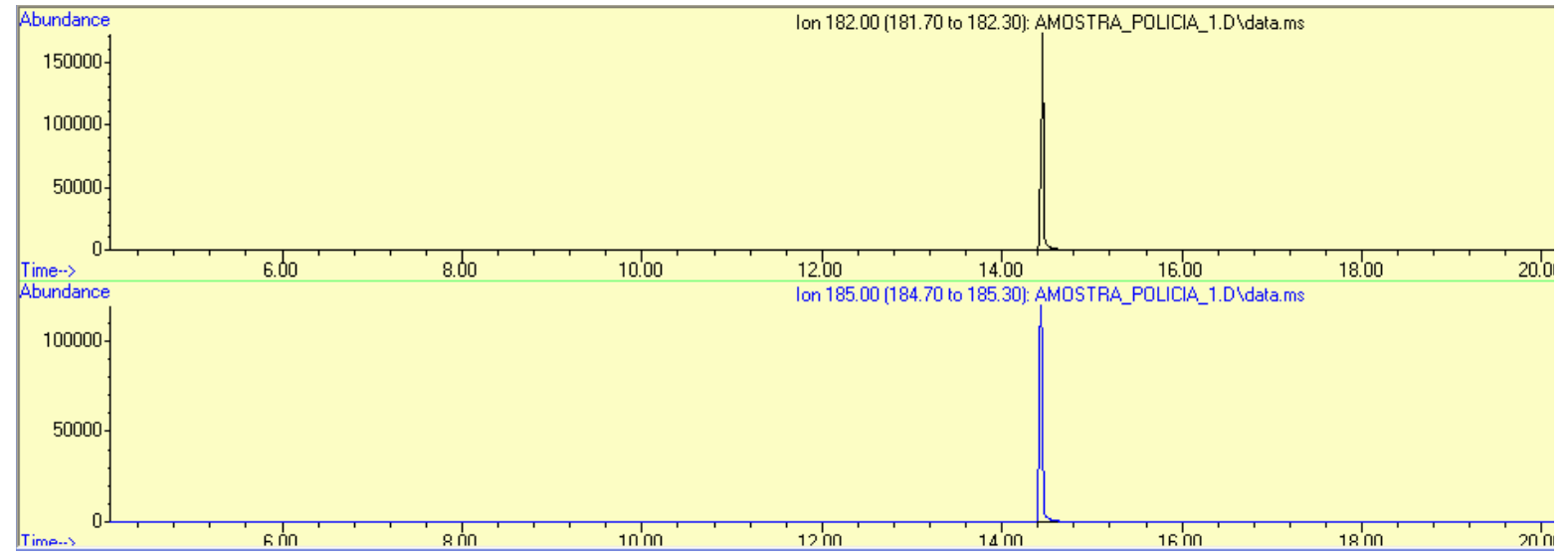

Figura 17. Na avaliação da pureza da cocaína, por GC-MS, foi empregado o modo de operação SIM, no qual os fragmentos de massa da cocaína $(82,182,303)$ e do padrão interno $(85,185,306)$ foram monitorados.

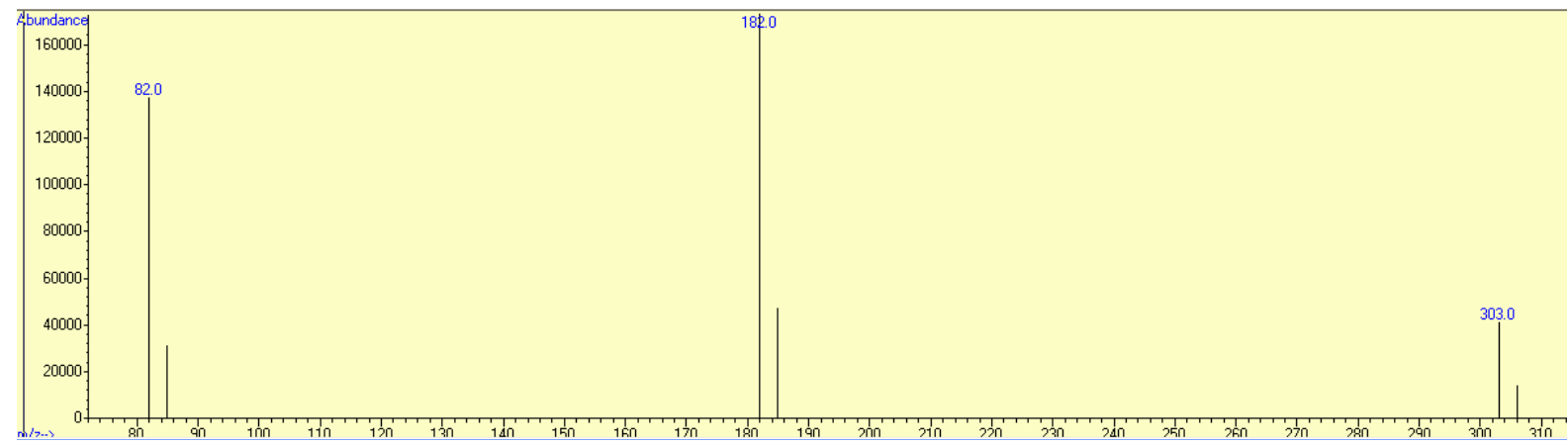




\subsubsection{Dosagem dos alcaloides da ayahuasca em amostra de chá por UPLC-ESI-MS/MS}

A Figura 18 mostra o cromatograma da amostra de chá de ayahuasca contendo DMT, HRM, HRL, THH e DMT- $d_{6}$ (padrão interno).

Figura 18. Cromatograma da amostra de chá de ayahuasca contendo 1. dimetiltriptamina (DMT), 3. tetrahidroarmina (THH), 4. harmalina (HRL), 5. harmina (HRM) e 2. DMT-d6 (padrão interno) após ter sido submetida à diluição seriada (1:5000) e análise por UPLC-ESIMS/MS.

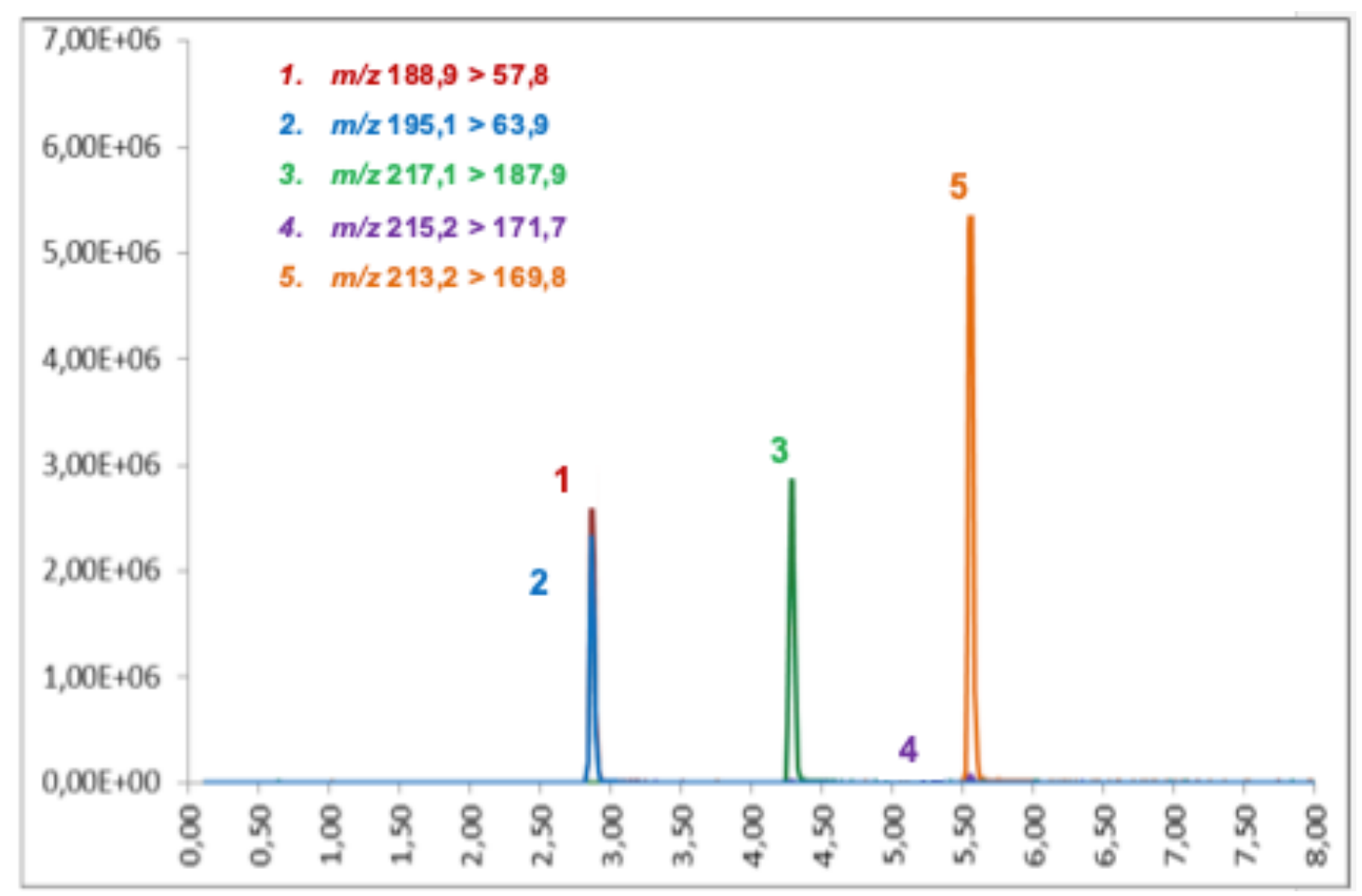

O método cromatográfico empregado mostrou-se adequado à identificação e quantificação de todos os analitos estudados. Embora a separação cromatográfica dos analitos não seja requisito obrigatório quando da utilização de UPLC-ESI-MS/MS com MRM, foi possível obter boa separação entre as $\beta$-carbolinas $H R M$ e $H R L$, que por sua similaridade estrutural, estavam inicialmente sobrepostas. Após modificações no gradiente de eluição e na composição da solução de fase móvel B de acetonitrila para metanol, a separação foi alcançada, pois a sobreposição dos analitos foi julgada possível fonte de supressão ou promoção da ionização e, portanto, eliminada.

A Tabela 10 faz referência aos resultados da quantificação dos alcaloides presentes no chá liofilizado de ayahuasca por UPLC-ESI-MS/MS. 
Tabela 10. Concentração de DMT e $\beta$-carbolinas presente na amostra de chá de ayahuasca determinada por UPLC-ESI-MS/MS.

\begin{tabular}{cc}
\hline Alcaloide & $\begin{array}{c}\text { Concentração } \\
(\mathrm{mg} / \mathrm{mL} ; \text { média } \pm \text { EPM })\end{array}$ \\
\hline N,N-dimetiltriptamina & $1,38 \pm 0,42$ \\
Harmina & $0,72 \pm 0,07$ \\
Harmalina & $0,11 \pm 0,04$ \\
Tetrahidroarmina & $0,84 \pm 0,20$ \\
\hline
\end{tabular}

\subsubsection{Composição da ayahuasca por dose}

Em nossos experimentos, utilizamos as seguintes doses de ayahuasca em diferentes concentrações de DMT, a saber: 1,76; 3; 15; 30 e $45 \mathrm{mg} / \mathrm{kg}$. Na Tabela 11, encontra-se a composição dos outros alcaloides constituintes da ayahuasca em cada uma das doses mencionadas.

Tabela 11. Composição dos principais alcaloides que compõem o chá de ayahuasca em cada uma das doses utilizadas neste trabalho. Os valores abaixo se referem à quantidade em miligramas tomando como base um camundongo de $25 \mathrm{~g}$. $H R M=$ harmina; $H R L=$ harmalina; $T H H=$ tetrahidroharmina; $A Y A=$ ayahuasca.

\begin{tabular}{cccccc}
\hline \multirow{2}{*}{ Alcaloides } & \multicolumn{5}{c}{ Composição da ayahuasca por dose $(\mathrm{mg})$} \\
& $1,76 \mathrm{mg} / \mathrm{kg}$ & $3 \mathrm{mg} / \mathrm{kg}$ & $15 \mathrm{mg} / \mathrm{kg}$ & $30 \mathrm{mg} / \mathrm{kg}$ & $45 \mathrm{mg} / \mathrm{kg}$ \\
DMT & 0,044 & 0,075 & 0,375 & 0,750 & 1,125 \\
HRM & 0,023 & 0,039 & 0,196 & 0,392 & 0,588 \\
HRL & 0,004 & 0,006 & 0,030 & 0,060 & 0,090 \\
THH & 0,027 & 0,046 & 0,228 & 0,456 & 0,684 \\
AYA & 2,414 & 4,115 & 20,575 & 41,150 & 61,725 \\
\hline
\end{tabular}




\subsection{Avaliação da influência da ayahuasca na atividade locomotora de camundongos em campo aberto}

A fim de estabelecer uma dose para os experimentos seguintes, analisou-se inicialmente a influência da administração aguda de ayahuasca na atividade locomotora de camundongos. Ainda que não tenha diferença estatística significante entre os grupos no primeiro dia de habituação no CA, percebe-se que a partir do segundo dia houve maior homogeneização na atividade locomotora total (Figura 19A). Em relação à administração de ayahuasca no terceiro dia experimental, não houve diferença estatística significativa ao analisar a atividade locomotora dos grupos (Figura 19B).

Nota-se que a atividade locomotora do grupo de camundongos que foi tratado com ayahuasca na dose de $1,76 \mathrm{mg} / \mathrm{kg}$ de DMT foi ligeiramente maior, mas não significativa, em relação ao controle. Ao passo que, a todo instante, o perfil de atividade locomotora desempenhado pelo grupo tratado com $3 \mathrm{mg} / \mathrm{kg}$ de DMT foi a todo instante semelhante com o grupo controle. As doses superiores de ayahuasca (17,6 e $30 \mathrm{mg} / \mathrm{kg}$ de DMT) sugerem ligeira diminuição na atividade durante a vigência da droga. O perfil de atividade locomotora dos animais com intervalos de 15 minutos e 30 minutos está representado na Figura 19C. 
Figura 19. Efeito da administração aguda de ayahuasca (AYA) na atividade locomotora de camundongos machos C57BI/6. Os animais foram habituados no campo aberto (CA) por 2 dias consecutivos durante $1 \mathrm{~h}$. Após 24 horas, receberam um desafio de ayahuasca: 0; 1,76; 3; 17,6 e $30 \mathrm{mg} / \mathrm{kg}$ de DMT e foram expostos imediatamente ao CA onde permaneceram por 1h. (A) Panorama geral da atividade locomotora dos animais durante os 3 dias experimentais. (B) Atividade locomotora dos animais no $3^{\circ}$ dia experimental (administração aguda de ayahuasca em diferentes doses). (C) Perfil da atividade locomotora dos animais com intervalo de 15 minutos (esquerda) e 30 minutos (direita). Dados expressos como média $\pm \operatorname{EPM}(n=5)$. A análise estatística para $(A)$ e $(C)$ foi realizada por ANOVA de duas vias com medidas repetidas e post-hoc de Bonferroni e; para (B), ANOVA de uma via e posthoc de Bonferroni.

0

\section{o}

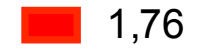

A
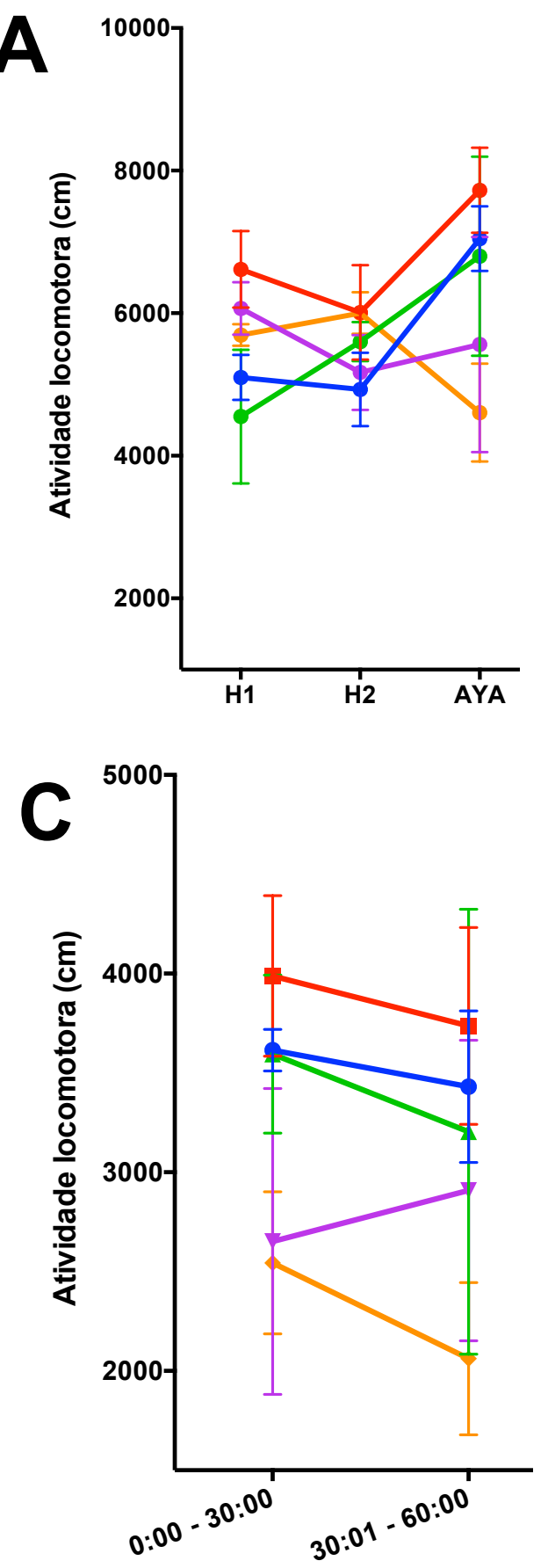

3

17,6
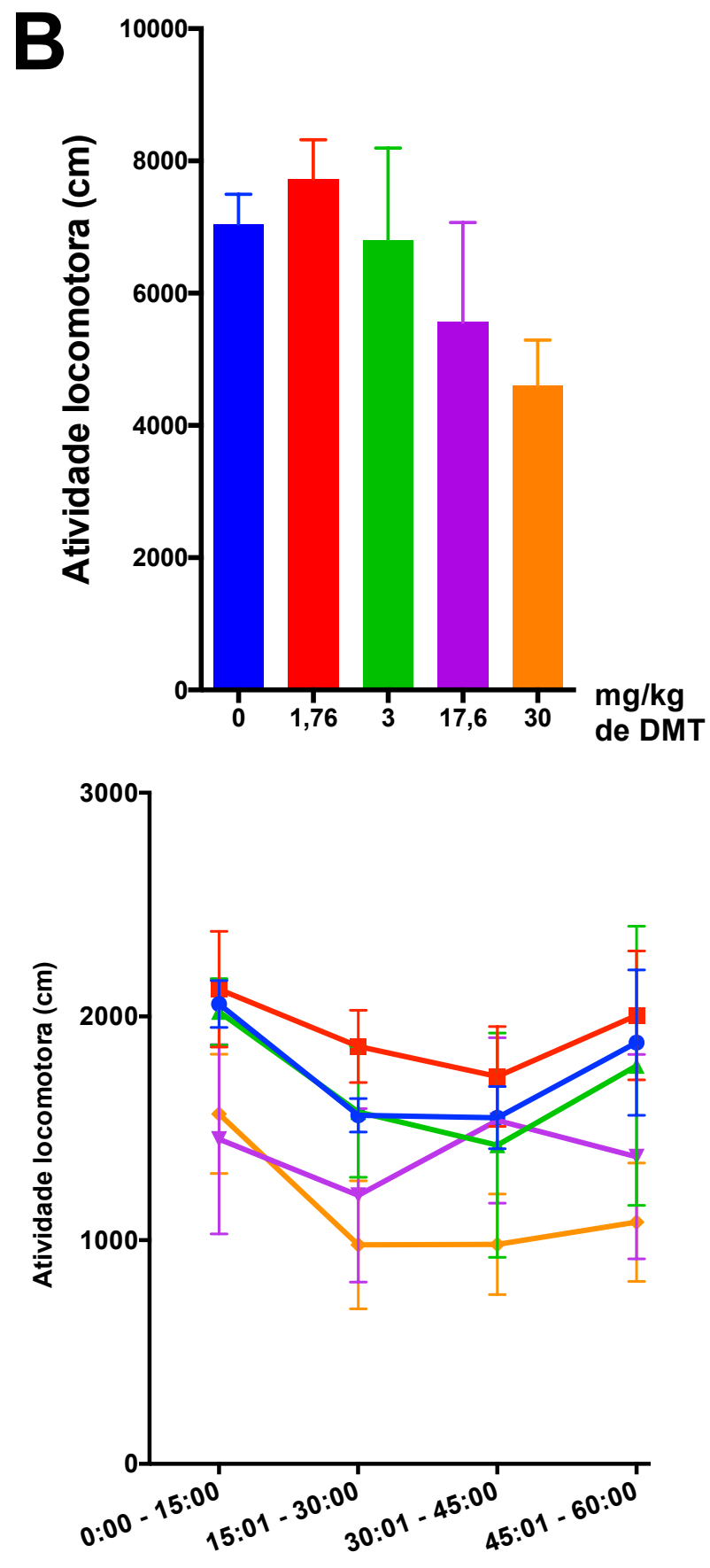


\subsection{Protocolo de prevenção da expressão da sensibilização}

comportamental induzida pela cocaína com ayahuasca na dose de $1,76 \mathrm{mg} / \mathrm{kg}$ de DMT

\subsubsection{Análise da atividade locomotora no campo aberto}

$\mathrm{Na}$ avaliação da aquisição da sensibilização comportamental induzida pela cocaína (10 mg/kg i.p.), observou-se que os animais tratados apresentaram elevação significativa da atividade locomotora logo no primeiro dia de administração em relação ao grupo controle $(p<0,0001)$. Após a aquisição da sensibilização (S2), a atividade locomotora manteve a mesma magnitude ao longo dos demais dias ( $p<0,05$ em relação ao $S 2$ ), exceto em S3. Conforme mostra a Figura 20A.

A Figura 20B apresenta a avaliação da prevenção da expressão da sensibilização comportamental induzida pela cocaína, utilizando ayahuasca na dose de $1,76 \mathrm{mg} / \mathrm{kg}$ de DMT. Não foram observadas diferenças estatísticas entre todos os grupos analisados. A ayahuasca não foi capaz de inibir a expressão da sensibilização comportamental (grupo CAC vs. CSC).

O panorama geral de atividade locomotora dos animais está apresentado na Figura 20C. 
Figura 20. Análise da prevenção da expressão da sensibilização comportamental, utilizando ayahuasca na dose de $1,76 \mathrm{mg} / \mathrm{kg}$ de DMT. Camundongos machos C57Bl/6 foram habituados durante 2 dias consecutivos no campo aberto (CA) após receberem administração de salina $0,9 \%$ i.p. No dia seguinte, iniciou-se o protocolo de sensibilização comportamental (S), no qual os animais receberam cocaína $10 \mathrm{mg} / \mathrm{kg}$ ou salina 0,9\% i.p. por 10 dias, em dias alternados (S1-S5) e, em seguida, foram exposto ao CA. Vinte e quatro horas depois, os animais receberam ayahuasca $(1,76 \mathrm{mg} / \mathrm{kg}$ de DMT) ou água filtrada v.o. durante 8 dias consecutivos (T1-T8) e após 30 minutos, foram submetidos ao CA. No $20^{\circ}$ dia, os animais foram desafiados com cocaína (DC) e imediatamente expostos ao CA e eutanasiados por decapitação. (A) Perfil da atividade locomotora dos animais tratados com cocaína $10 \mathrm{mg} / \mathrm{kg}$ i.p. durante a aquisição da sensibilização comportamental. ANOVA de duas vias e post-hoc de Bonferroni, utilizando os dados de atividade locomotora dos grupos salina ( $n=15)$ e cocaína ( $n=14)$. Dados expressos como média $\pm E P M .{ }^{*} p<0,05,{ }^{* * * *} p<0,0001$ em relação ao dia anterior no mesmo grupo analisado. \#\#\# $p<0,0001$ vs. salina no mesmo dia de análise. (B) Análise da prevenção da expressão da sensibilização comportamental induzida pela cocaína pela ayahuasca. ANOVA de uma via e post-hoc de Bonferroni, utilizando os dados dos grupos SSC ( $n=3), \operatorname{CSC}(n=3), \operatorname{CAC}(n=3)$ no dia do desafio com cocaína. Dados expressos como média \pm EPM. (C) Panorama geral da atividade locomotora.
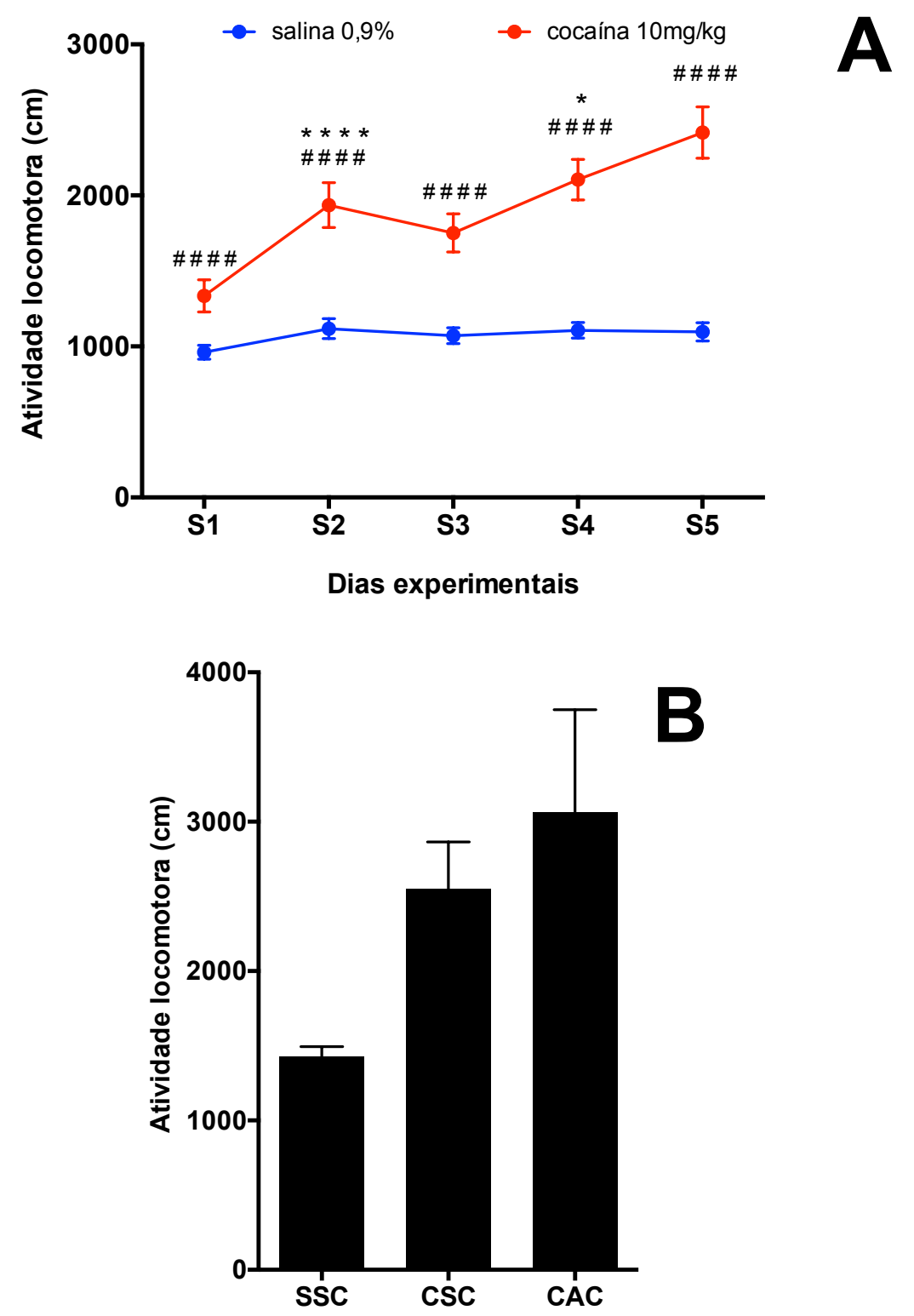


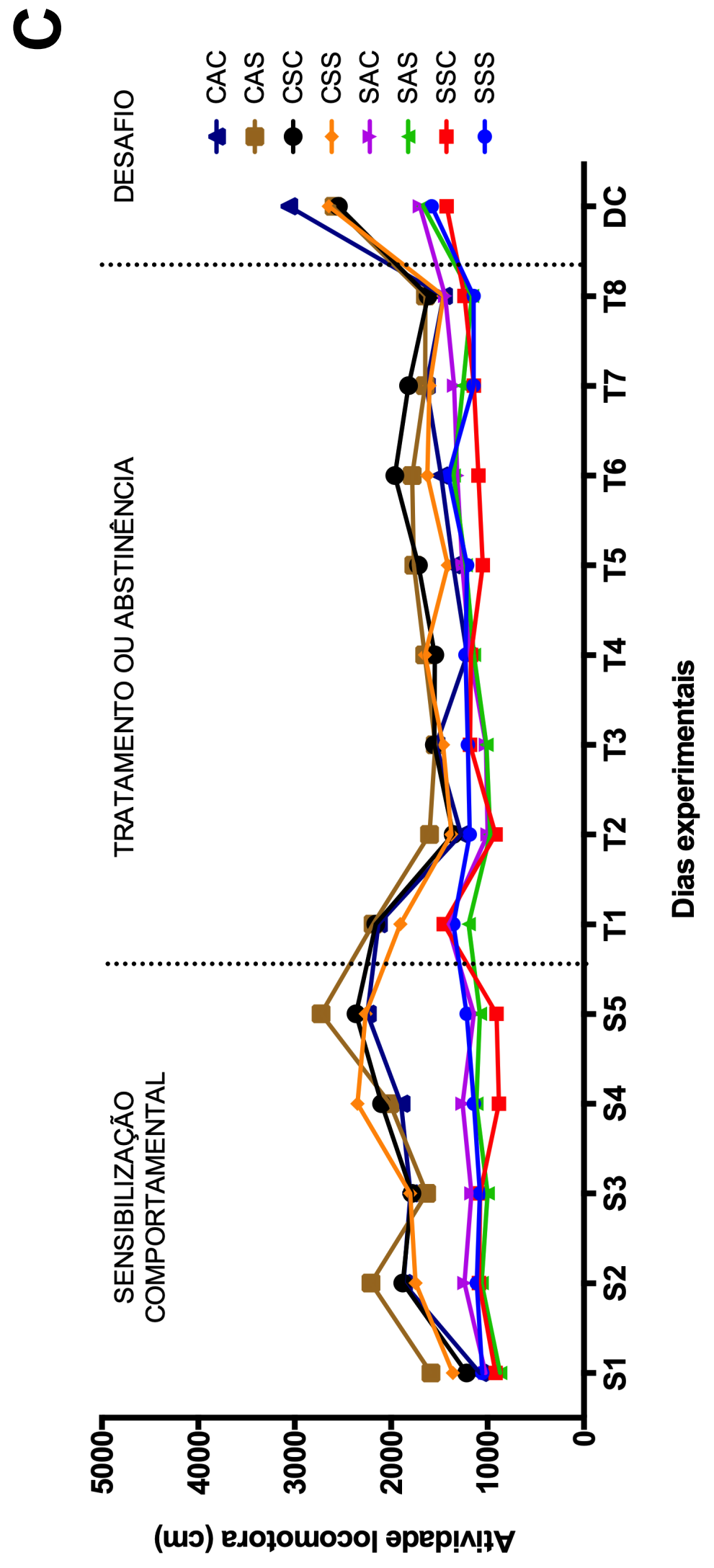




\subsubsection{Análise comportamental no labirinto em cruz elevado}

O tempo de permanência nos braços abertos ou fechados foi calculado como porcentagem do tempo total despedido em ambos os braços (Figura 21A). A Figura 21B mostra o número de entradas nos braços abertos ou fechados (em porcentagem). Não foram observadas diferença estatística entre os grupos estudados em ambos os casos.

Figura 21. Análise no labirinto em cruz elevado após o tratamento de 7 dias consecutivos com ayahuasca $1,76 \mathrm{mg} / \mathrm{kg}$ de DMT. (A). À esquerda, porcentagem de tempo no braço aberto e, à direita, porcentagem de tempo no braço fechado. (B). À esquerda, porcentagem de entrada no braço aberto e, à direita, porcentagem de entrada no braço fechado. Dados expressos como média \pm EPM (Sal-Sal, $n=8$; Sal-Aya, $n=8$; Coc-Sal, $n=6$; Coc-Aya, $n=4$ ). ANOVA de uma via e post-hoc de Bonferroni.
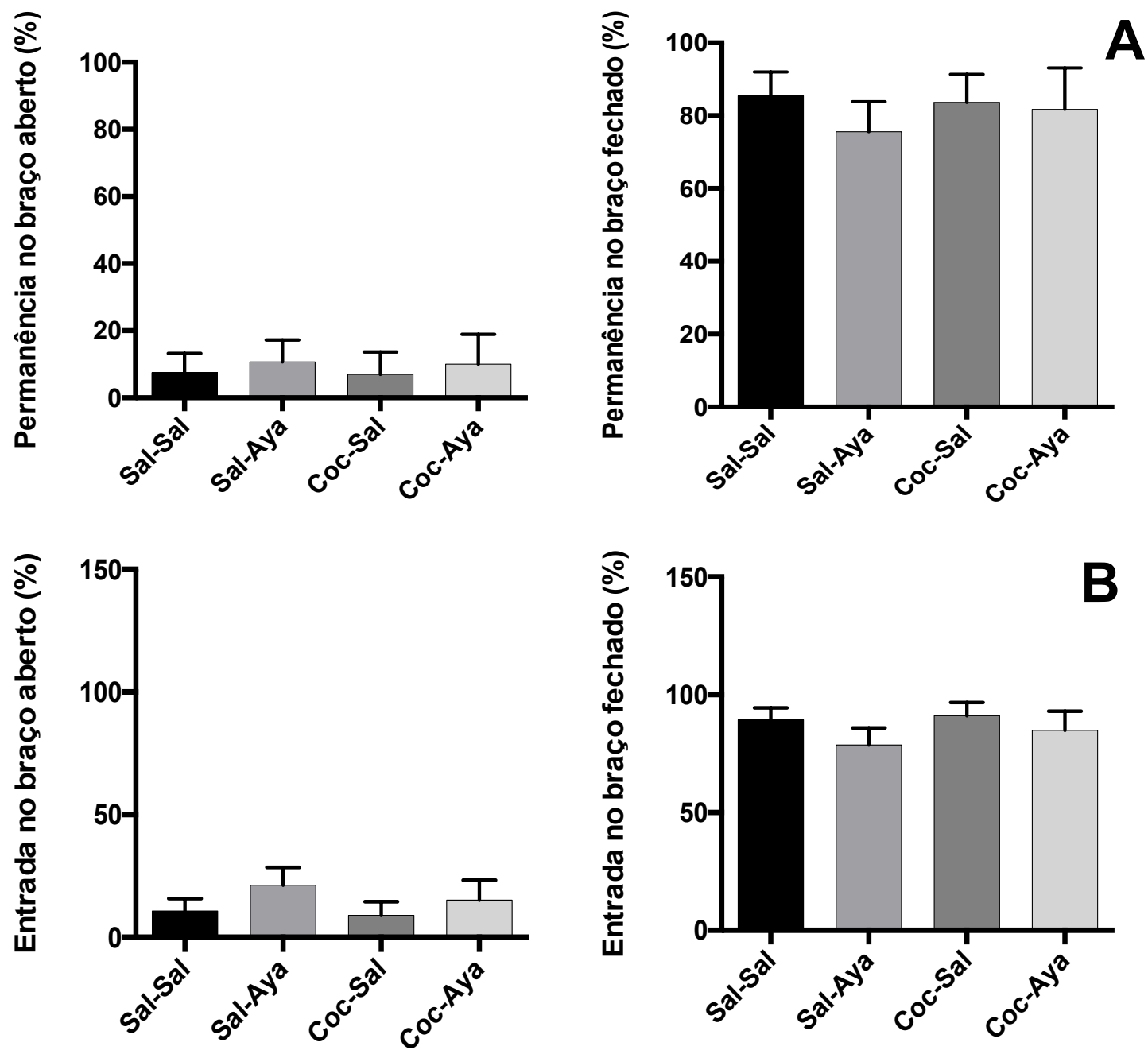


\subsubsection{Dosagem de cocaína e benzoilecgonina em amostras de plasma de camundongo por UPLC-ESI-MS/MS}

A Tabela 12 apresenta os resultados das dosagens plasmáticas de cocaína e benzoilecgonina por UPLC-ESI-MS/MS, em ng/mL. Para o grupo sensibilizado com cocaína, a coleta de sangue foi realizada no último dia de sensibilização comportamental. E, para os demais grupos, a coleta foi realizada no último dia experimental. Ambas coletas ocorreram logo após a saída dos animais do CA.

Tabela 12. Concentração plasmática de cocaína e benzoilecgonina $(n g / m L)$ do grupo de animais sensibilizados com cocaína $10 \mathrm{mg} / \mathrm{kg}$ i.p. no último dia de sensibilização comportamental e dos grupos desafiados com cocaína no último dia experimental. A coleta ocorreu imediatamente após a saída dos camundongos do CA $(n=4)$.

\begin{tabular}{ccc}
\hline & $\begin{array}{c}\text { Concentração de cocaína } \\
(\mathrm{ng} / \mathrm{mL} ; \text { média } \pm \mathrm{EPM})\end{array}$ & $\begin{array}{c}\text { Concentração de benzoilecgonina } \\
(\mathrm{ng} / \mathrm{mL} ; \text { média } \pm \mathrm{EPM})\end{array}$ \\
\hline $\begin{array}{c}\text { Grupo sensibilizado } \\
\text { com cocaína }\end{array}$ & $9,61 \pm 9,99$ & $39,93 \pm 15,90$ \\
SSC & $14,91 \pm 8,71$ & $40,12 \pm 13,26$ \\
SAC & $11,05 \pm 6,69$ & $72,34 \pm 15,90$ \\
CSC & $20,53 \pm 16,81$ & $83,77 \pm 39,39$ \\
CAC & $5,89 \pm 9,23$ & $54,16 \pm 7,17$ \\
\hline
\end{tabular}




\subsection{Avaliação do efeito agudo da ayahuasca (3 $\mathrm{mg} / \mathrm{kg}$ de DMT) na atividade locomotora de camundongos em resposta à cocaína}

Este experimento teve o intuito de avaliar o efeito agudo da ayahuasca (3,0 $\mathrm{mg} / \mathrm{kg}$ de DMT v.o.) como possível fator protetor sob os efeitos psicoestimulantes da cocaína (10 mg/kg i.p.). Observa-se na Figura 22, que não houve efeito protetor da ayahuasca quando administrada de forma aguda.

Figura 22. Efeito inibidor da ayahuasca $(3,0 \mathrm{mg} / \mathrm{kg}$ de DMT) sob a atividade locomotora de camundongos machos C57BI/6 trataddos com cocaina. Os animais foram, inicialmente, divididos em dois grupos experimentais: um recebeu água filtrada v.o., formando o grupo Ctrl $(n=14)$ e o outro recebeu ayahuasca (3,0 mg/kg de DMT v.o.), formando o grupo Aya $(n=$ 14). Os animais foram colocados imediatamente no campo aberto (CA) durante $30 \mathrm{~min}$. $A$ seguir, metade do Ctrl recebeu salina 0,9\% i.p., formando o grupo Ctrl-Ctrl (n=7) e a outra metade recebeu cocaína $10 \mathrm{mg} / \mathrm{kg}$ i.p., formando o grupo Ctrl-Coca $(n=7)$. 0 mesmo procedimento foi realizado com os animais do grupo Aya, formando os grupos Aya-Ctrl $(n=$ 7) e Aya-Coca $(n=7)$. Imediatamente após a segunda administração, os animais retornaram ao CA por 30 minutos. Dados expressos como média \pm EPM. A primeira parte do experimento foi analisada com Teste " $t$ " de Student para amostras não pareadas; $e$ a segunda, ANOVA de uma via e post-hoc de Bonferroni. ${ }^{* *} p<0,01$; ${ }^{* * *} p<0,001$.

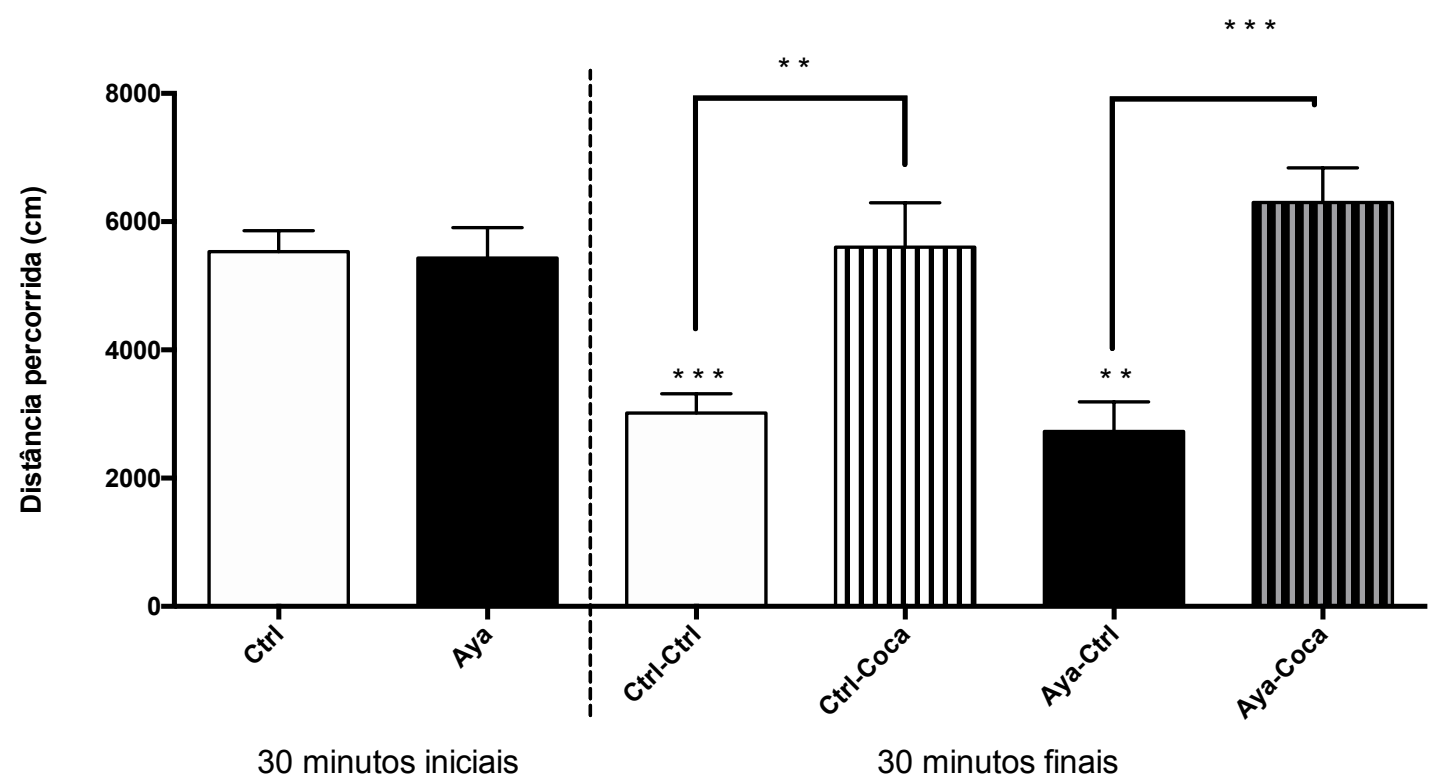




\subsection{Protocolo de prevenção da expressão da sensibilização}

comportamental induzida pela cocaína com ayahuasca na dose de $3 \mathrm{mg} / \mathrm{kg}$ de DMT

Não houve diferença entre os grupos durante o período de habituação $(H)$. Durante a aquisição da sensibilização comportamental, a atividade locomotora do grupo cocaína foi superior a do grupo salina $(p<0,0001)$ e em relação ao último dia de habituação $(p<0,0001)$. Durante o período de sensibilização comportamental, notou-se que houve aquisição deste fenômeno logo no segundo dia de administração de cocaína, uma vez que a atividade locomotora dos camundongos se mostrou significativamente maior que no primeiro dia $(p<0,01)$. A magnitude da atividade locomotora dos animais continuou crescente nos outros dias, sendo significativamente diferente do S4 em relação ao S3 ( $p<0,05)$, conforme a Figura 23A.

A Figura 23B representa a avaliação da prevenção da expressão da sensibilização comportamental induzida pela cocaína, utilizando ayahuasca na dose de $3 \mathrm{mg} / \mathrm{kg}$ de DMT. A atividade locomotora dos animais pertencentes ao grupo CSC foi superior ao grupo SSC $(p<0,05)$. No entanto, atividade locomotora dos grupos CSC e CAC foram semelhantes, sugerindo que a ayahuasca nesta dose não é capaz de prevenir o fenômeno da expressão da sensibilização induzida pela cocaína. Não houve diferença estatística comparando os grupos SSS e SAS, inferindo que a ayahuasca não influenciou na atividade locomotora dos camundongos no dia do desafio cocaína.

O panorama geral de atividade locomotora dos animais está representado na Figura 23C. 
Figura 23. Prevenção da expressão da sensibilização comportamental, utilizando ayahuasca na dose de $3 \mathrm{mg} / \mathrm{kg}$ de DMT. Camundongos machos C57Bl/6 foram habituados por 3 dias consecutivos (H1-H3) no campo aberto (CA), logo após receberam salina 0,9\%. Vinte e quatro horas depois, os animais foram sensibilizados (S) com cocaína $10 \mathrm{mg} / \mathrm{kg}$ ou salina 0,9\% i.p. durante 10 dias, em dias alternados (S1-S5). Após o período de sensibilização comportamental, os animais receberam ayahuasca (3 $\mathrm{mg} / \mathrm{kg}$ de DMT) ou água filtrada v.o. por 8 dias consecutivos (T1-T8). No $21^{\circ}$ dia, foi feito desafio com salina (DS) 0,9\% i.p. e, no dia seguinte, com cocaína (DC) $10 \mathrm{mg} / \mathrm{kg}$ i.p. Em todos os dias de manipulação, a atividade locomotora dos animais foi avaliada em CA por 30 minutos. No último dia experimental, logo após a exposição dos animais ao CA, os camundongos foram eutanasiados. (A) Perfil da atividade locomotora dos animais tratados com cocaína $10 \mathrm{mg} / \mathrm{kg}$ i.p. durante a aquisição da sensibilização comportamental. ANOVA de duas vias e post-hoc de Bonferroni, utilizando os dados de atividade locomotora dos grupos salina $(n=35)$ e cocaína ( $n=24)$ durante o período de aquisição da sensibilização comportamental induzida pela cocaína. Dados expressos como média $\pm E P M$. $\left.{ }^{*} p<0,05\right) e^{* *} p<0,01$ vs. dia anterior no mesmo grupo. \#\#\# $p<0,0001$ vs. grupo salina no mesmo dia. (B) Análise da prevenção da expressão da sensibilização comportamental induzida pela cocaína pela ayahuasca. ANOVA de uma via e post-hoc de Bonferroni, utilizando os dados dos grupos SSC ( $n=12) ; \operatorname{CSC}(n=12) ; \operatorname{CAC}(n=12)$ no dia do desafio com cocaína. Dados expressos como média \pm EPM. ${ }^{*} p<0,05$. (C) Panorama geral da atividade locomotora.
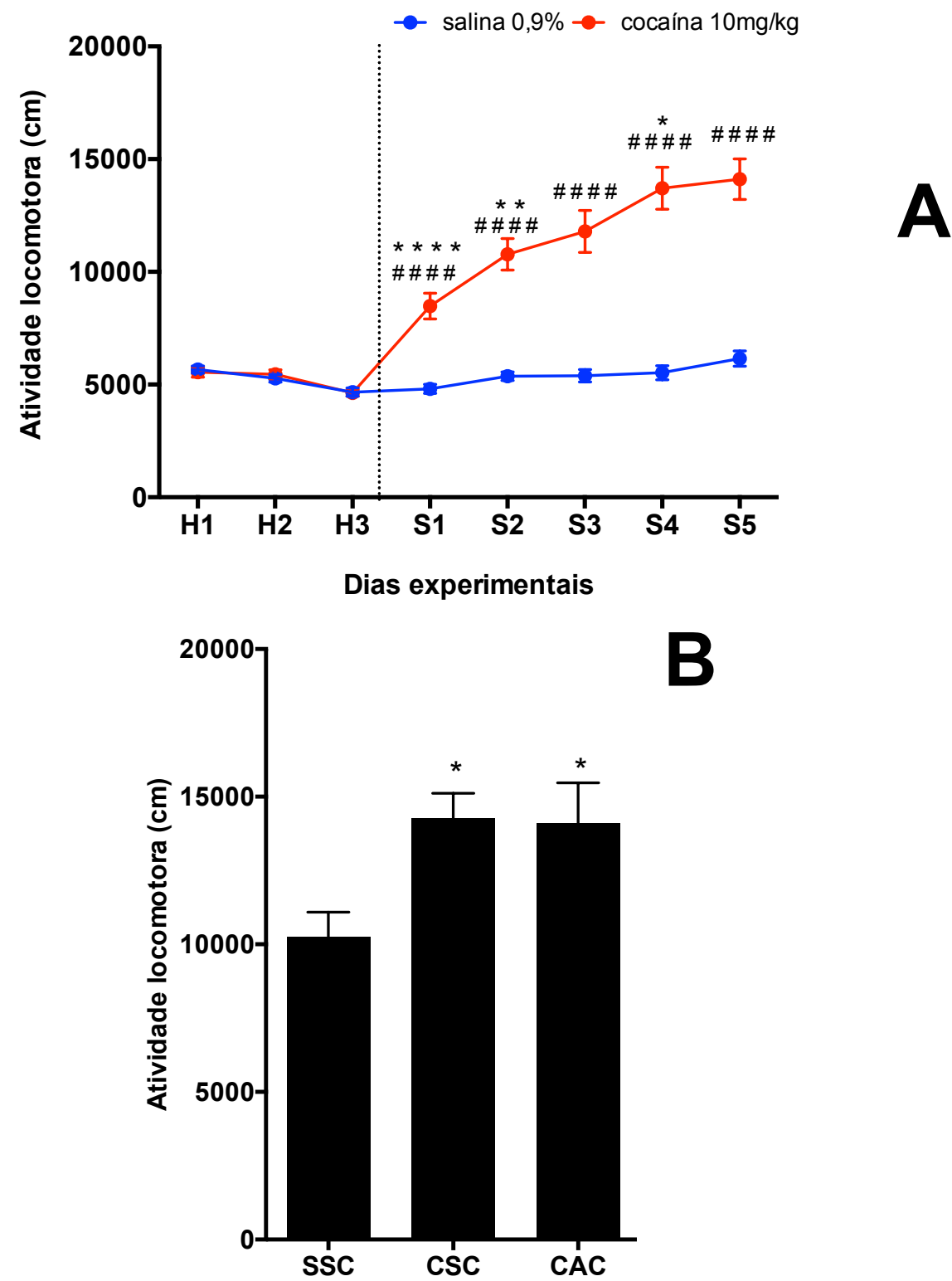
0

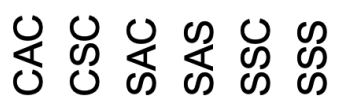

$\phi \uparrow \mid \uparrow \phi \phi$

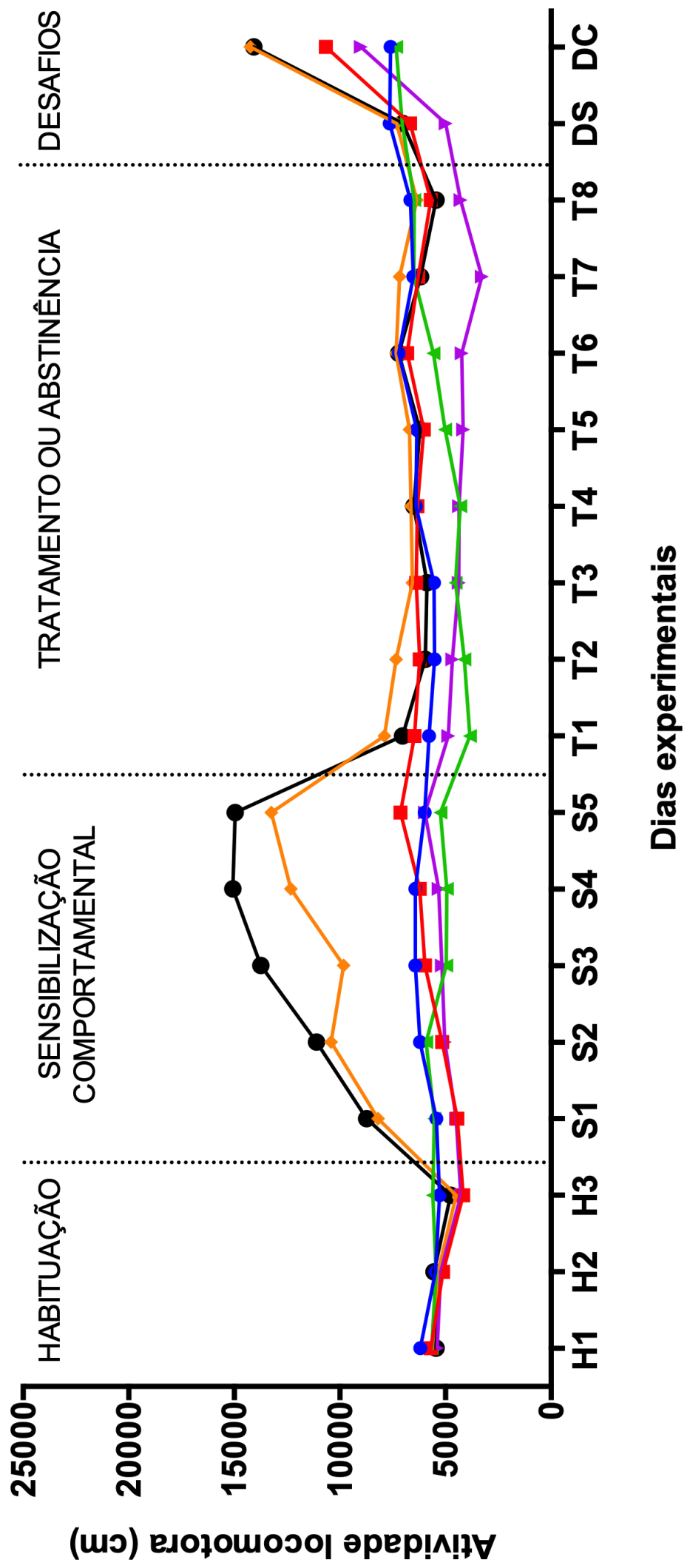




\subsection{Protocolo de prevenção da expressão da sensibilização}

comportamental induzida pela cocaína utilizando ayahuasca nas doses de 15, 30 e $45 \mathrm{mg} / \mathrm{kg}$ de DMT

$\mathrm{Na}$ análise da prevenção da sensibilização comportamental induzida pela cocaína utilizando doses superiores de ayahuasca, observou-se redução na atividade locomotora para as três doses utilizadas, sendo: $15 \mathrm{mg} / \mathrm{kg}$ de DMT $(p<0,01) ; 30 \mathrm{mg} / \mathrm{kg}(p<0,01)$ e $45 \mathrm{mg} / \mathrm{kg}(p<0,001)$, conforme a Figura 24.

Figura 24. Prevenção da expressão da sensibilização comportamental, utilizando ayahuasca nas doses 15, 30 e $45 \mathrm{mg} / \mathrm{kg}$ de DMT. ANOVA de uma via e post-hoc de Bonferroni, utilizando os dados de atividade locomotora dos grupos SSC ( $n=12), C S C$ (n=12), CAC(3) ( $n=12), C A C(15)$ $(n=11), C A C(30)(n=5)$ e $C A C(45)(n=5)$ no dia do desafio com cocaína. Dados expressos como média $\pm E P M$. @p<0,05 vs. SSC; ${ }^{* *} p<0,01,{ }^{* * *} p<0,001$ vs. CSC; \#p<0,01 e \#\#p<0,001, vs. $C A C(3)$.

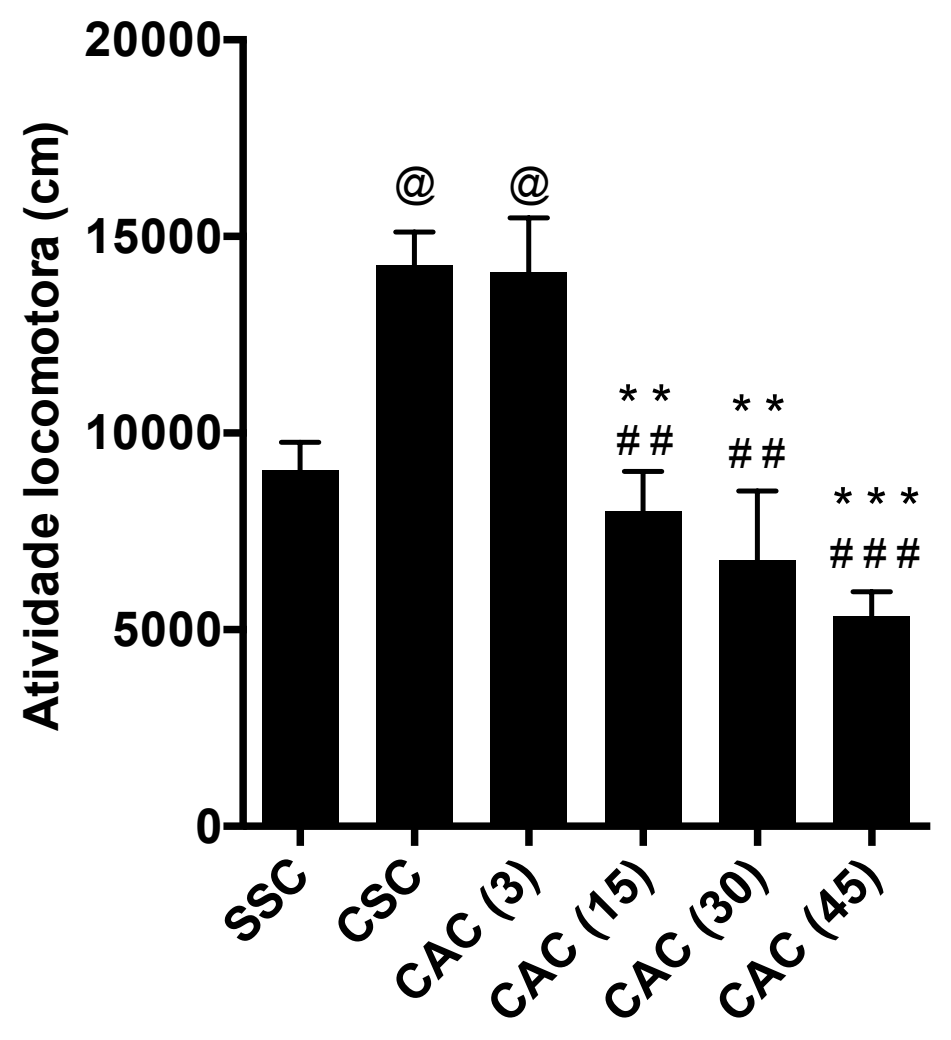




\subsection{Protocolo de prevenção da expressão da sensibilização}

comportamental induzida pela cocaína com ayahuasca na dose de $15 \mathrm{mg} / \mathrm{kg}$ de DMT

\subsubsection{Avaliação da atividade locomotora em campo aberto}

No período de habituação $(H)$, os grupos que posteriormente foram tratados com salina $0,9 \%$ e cocaína $10 \mathrm{mg} / \mathrm{kg}$ i.p. permaneceram com atividade locomotora bastante semelhante, exceto no $\mathrm{H} 3$, quando a atividade do grupo cocaína foi superior ao grupo salina $(p<0,05)$.

Ao iniciar o período de sensibilização comportamental, observou-se que a atividade locomotora do grupo cocaína foi superior a do grupo salina $(p<0,0001)$ e em relação ao último dia de habituação $(p<0,0001)$. Apesar de não ter sido significativa, a atividade locomotora dos camundongos do grupo durante o período de sensibilização comportamental teve um perfil sempre crescente (Figura 25A)

A Figura 25B mostra a avaliação da prevenção da expressão da sensibilização comportamental induzida pela cocaína, utilizando ayahuasca na dose de $15 \mathrm{mg} / \mathrm{kg}$ de DMT. A atividade locomotora dos animais pertencentes ao grupo CSC foi superior ao grupo SSC $(p<0,05)$ e SSS $(p<$ $0,001)$, evidenciando a expressão da sensibilização anteriormente induzida. $\mathrm{E}$, a atividade locomotora do grupo tratado com $15 \mathrm{mg}$ de ayahuasca (CAC) foi menor $(p<0,01)$ que a atividade do grupo não tratado (CSC), sugerindo que a ayahuasca nesta dose é capaz de prevenir da expressão da sensibilização à cocaína. Não houve diferença estatística comparando os grupos SSS e SAS, inferindo que a ayahuasca não influenciou na atividade locomotora dos camundongos no dia do desafio cocaína (Figura 25C).

O panorama geral de atividade locomotora dos animais está representado na Figura 25D. 
Figura 25. Protocolo de prevenção da expressão da sensibilização comportamental, utilizando ayahuasca na dose de $15 \mathrm{mg} / \mathrm{kg}$ de DMT. Os camundongos foram inicialmente habituados por 3 dias consecutivos (H1-H3) no campo aberto (CA), logo após receberam salina $0,9 \%$. Vinte e quatro horas depois, os camundongos foram sensibilizados (S) com cocaína $10 \mathrm{mg} / \mathrm{kg}$ ou salina 0,9\% i.p. durante cinco dias alternados (S1-S5). Após o período de sensibilização comportamental, os animais receberam ayahuasca (15 mg/kg de DMT) ou água filtrada v.o. por oito dias consecutivos (T1-T8). No $21^{\circ}$ dia, foi feito desafio com salina (DS) 0,9\% i.p. e, no dia seguinte, com cocaína (DC) $10 \mathrm{mg} / \mathrm{kg}$ i.p. Em todos os dias de manipulação, a atividade locomotora dos animais foi avaliada em CA por 30 minutos. No último dia experimental, logo após a exposição dos animais ao CA, os camundongos foram eutanasiados. (A) Perfil da atividade locomotora dos animais tratados com cocaína $10 \mathrm{mg} / \mathrm{kg}$ i.p. durante o protocolo de aquisição da sensibilização comportamental. ANOVA de duas vias e post-hoc de Bonferroni, utilizando os dados de atividade locomotora dos grupos salina $(n=48)$ e cocaína ( $n=21)$ durante o período de aquisição da sensibilização comportamental induzida pela cocaína. Dados expressos como média $\pm E P M$. ${ }^{* * * *} p<0,0001$ representa diferença estatística em relação ao dia anterior no mesmo grupo analisado. \#p<0,05 e \#\#\#p<0,0001 representa diferença estatística em relação ao grupo salina no mesmo dia de análise. (B) Análise da prevenção da expressão da sensibilização comportamental induzida pela cocaína pela ayahuasca. Análise realizada por ANOVA de uma via e post-hoc de Bonferroni, utilizando os dados de atividade locomotora dos grupos SSC (n=12); CSC ( $n=9)$; CAC $(n=12)$ no dia do desafio com cocaína. Dados expressos como média $\pm E P M$. ${ }^{*} p<0,05$ representa diferença estatística quando comparado com o grupo SSC; \#p<0,05 representa diferença estatística quando comparado com o grupo CSC. (C) Comparação entra a atividade locomotora dos grupos SSS e SAS no desafio cocaína. Análise realizada por Teste " $t$ " de Student para amostras não pareadas; (D) Panorama geral da atividade locomotora dos grupos experimentais.

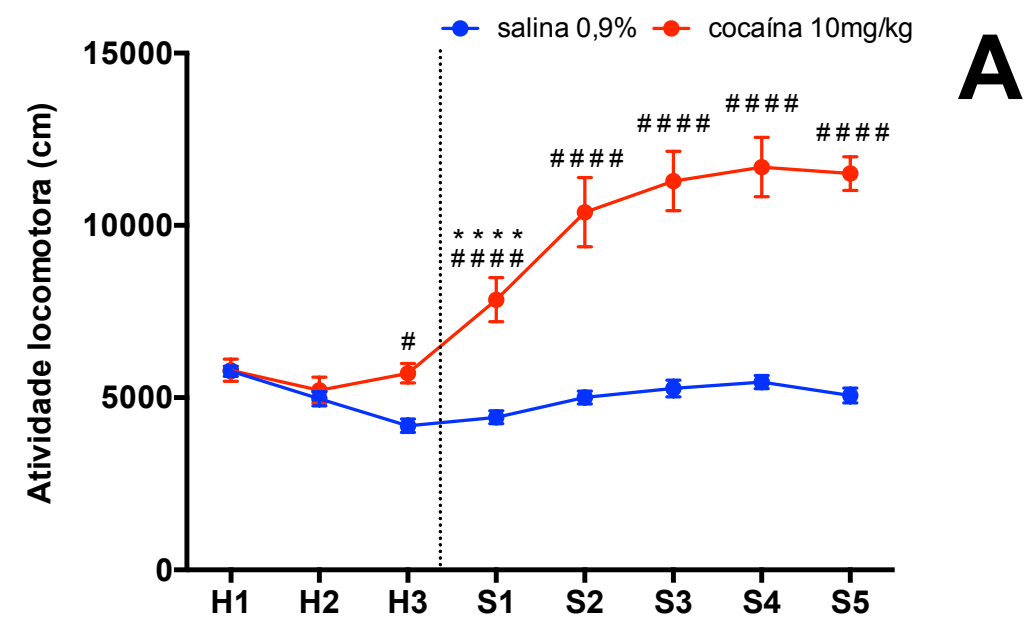

Dias experimentais
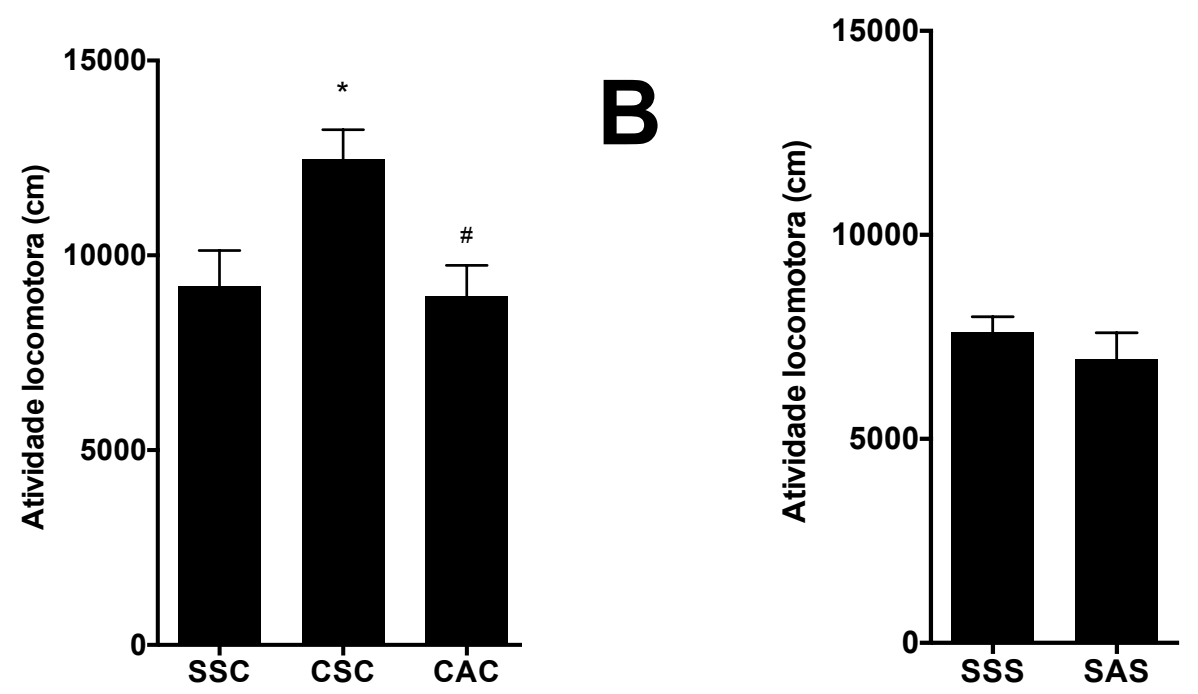


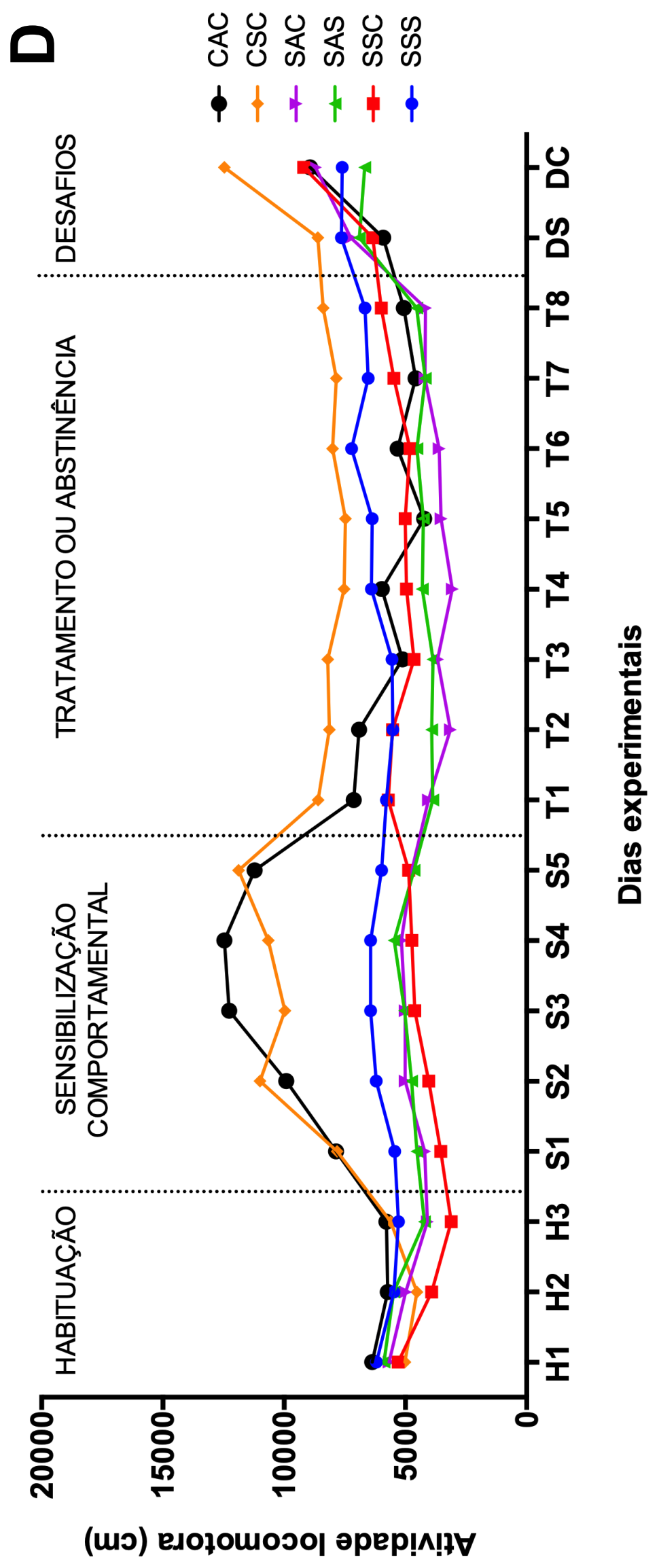




\subsubsection{Análise proteica nas estruturas alvo por immunoblotting}

\subsubsection{Córtex pré-frontal}

A Figura 26 apresenta a quantificação dos receptores serotoninérgicos $5-\mathrm{HT}_{1 \mathrm{~A}}$ (superior) e $5-\mathrm{HT}_{2 \mathrm{~A}}$ (inferior) no córtex pré-frontal. Não foram observadas nenhuma alteração significativa em suas densidades nessa região.

Figura 26. Quantificação dos receptores serotoninérgicos $5-H T_{1 A}(n=8)$ e $5-H T_{2 A}(n=8)$ por immunoblotting no córtex pré-frontal de camundongos machos C57BI/6. Os camundongos foram inicialmente habituados no campo aberto (CA) logo após administração de salina 0,9\% i.p. por 3 dias consecutivos. Vinte e quatro horas depois, foram sensibilizados com salina ou cocaína $10 \mathrm{mg} / \mathrm{kg}$ i.p. por 10 dias, em dias alternados. A seguir, receberam ayahuasca 15 $\mathrm{mg} / \mathrm{kg}$ de DMT ou água filtrada por gavagem durante 8 dias consecutivos. No dia seguinte, receberam um desafio salina e 24 horas depois, foram desafiados com salina ou cocaína. Durante todos os dias experimentais, os camundongos foram expostos ao CA por 30 minutos para a análise da atividade locomotora. Após a última exposição ao $C A$, os animais foram eutanasiados por decapitação e o córtex pré-frontal dissecado e preparado para análise. ANOVA de uma via e post-hoc de Turkey. Dados expressos como \% em relação ao controle (média $\pm E P M)$.
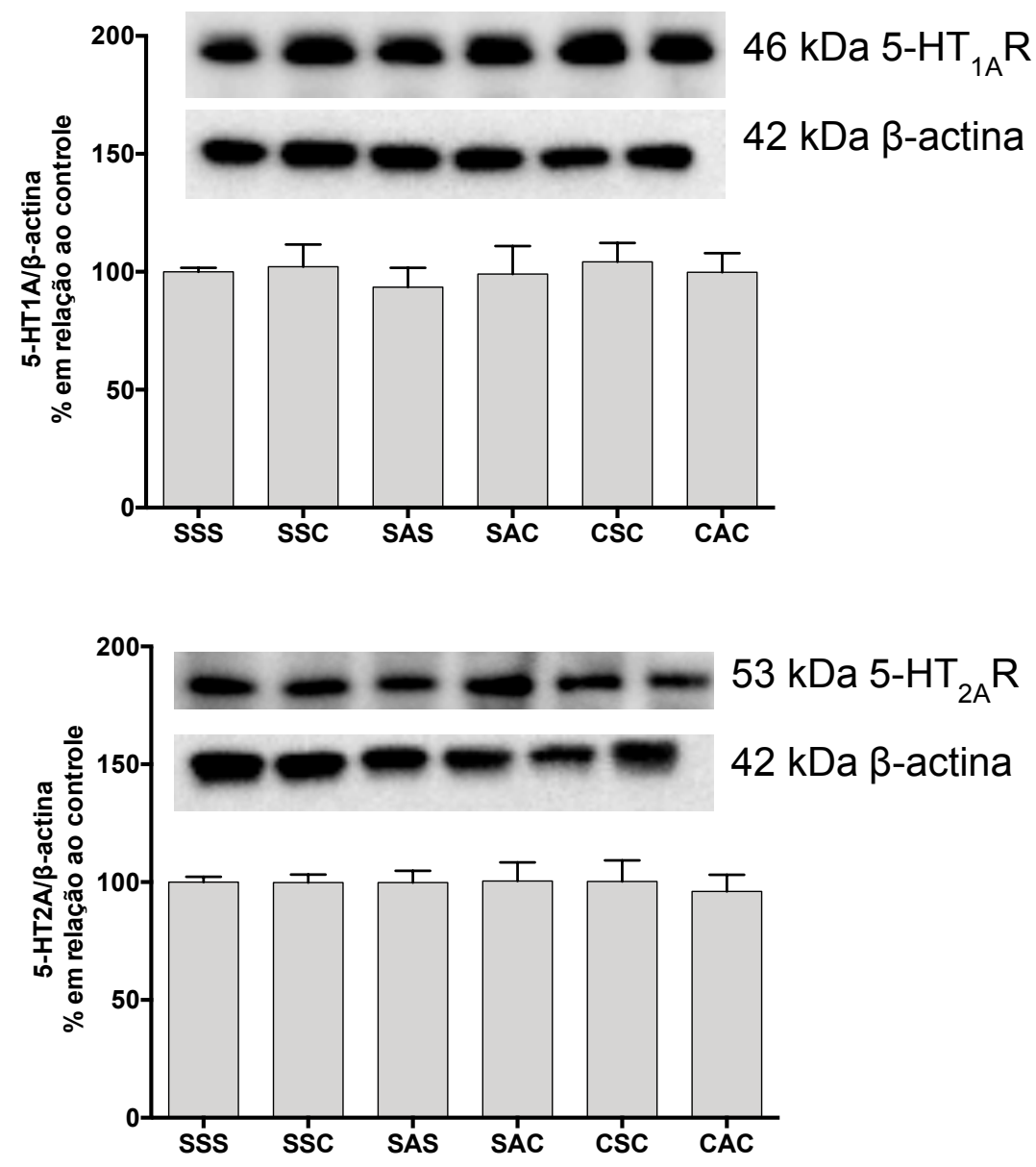


\subsubsection{Estriado}

A Figura 27 apresenta a quantificação dos receptores serotoninérgicos 5- $\mathrm{HT}_{1 \mathrm{~A}}$ (superior) e 5- $\mathrm{HT}_{2 \mathrm{~A}}$ (inferior) no estriado. Não foram observadas nenhuma alteração significativa em suas densidades nessa região.

Figura 27. Quantificação dos receptores serotoninérgicos $5-H T_{1 A}(n=8)$ e $5-H T_{2 A}(n=7)$ por immunoblotting no estriado de camundongos machos C57BI/6. Os camundongos foram inicialmente habituados no campo aberto (CA) logo após administração de salina 0,9\% i.p. por 3 dias consecutivos. Vinte e quatro horas depois, foram sensibilizados com salina ou cocaína $10 \mathrm{mg} / \mathrm{kg}$ i.p. por 10 dias, em dias alternados. A seguir, receberam ayahuasca (15 $\mathrm{mg} / \mathrm{kg}$ de DMT) ou água filtrada por gavagem durante 8 dias consecutivos. No dia seguinte, receberam um desafio salina e 24 horas depois, foram desafiados com salina ou cocaína. Durante todos os dias experimentais, os camundongos foram expostos ao CA por 30 minutos para a análise da atividade locomotora. Após a última exposição ao CA, os animais foram eutanasiados por decapitação e o estriado dissecado e preparado para análise. ANOVA de uma via e post-hoc de Turkey. Dados expressos como \% em relação ao controle (média \pm EPM).
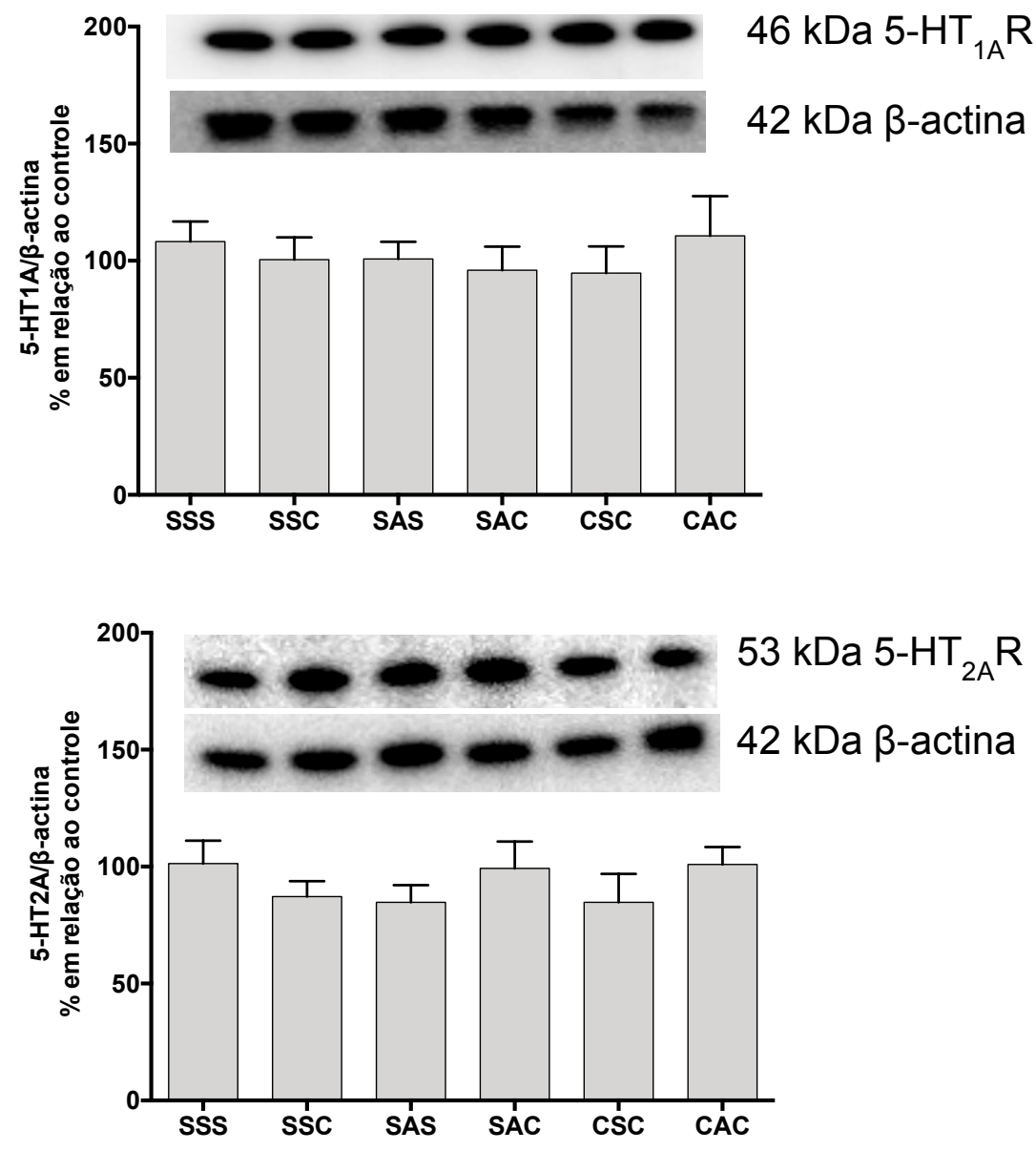


\subsubsection{Hipocampo}

A Figura 28 apresenta a quantificação dos receptores serotoninérgicos 5- $\mathrm{HT}_{1 \mathrm{~A}}$ (superior) e 5- $\mathrm{HT}_{2 \mathrm{~A}}$ (inferior) no hipocampo. Não foram observadas nenhuma alteração significativa em suas densidades nessa região.

Figura 28. Quantificação dos receptores serotoninérgicos $5-H T_{1 A}(n=8)$ e $5-H T_{2 A}(n=8)$ por immunoblotting no hipocampo de camundongos machos C57Bl/6. Os camundongos foram inicialmente habituados no campo aberto (CA) logo após administração de salina 0,9\% i.p. por 3 dias consecutivos. Vinte e quatro horas depois, foram sensibilizados com salina ou cocaína $10 \mathrm{mg} / \mathrm{kg}$ i.p. por 10 dias, em dias alternados. A seguir, receberam ayahuasca (15 $\mathrm{mg} / \mathrm{kg}$ de DMT) ou água filtrada por gavagem durante 8 dias consecutivos. No dia seguinte, receberam um desafio salina e 24 horas depois, foram desafiados com salina ou cocaína. Durante todos os dias experimentais, os camundongos foram expostos ao CA por 30 minutos para a análise da atividade locomotora. Após a última exposição ao CA, foram eutanasiados por decapitação e hipocampo dissecado e preparado para análise. ANOVA de uma via e post-hoc de Turkey. Dados expressos como \% em relação ao controle (média \pm EPM).
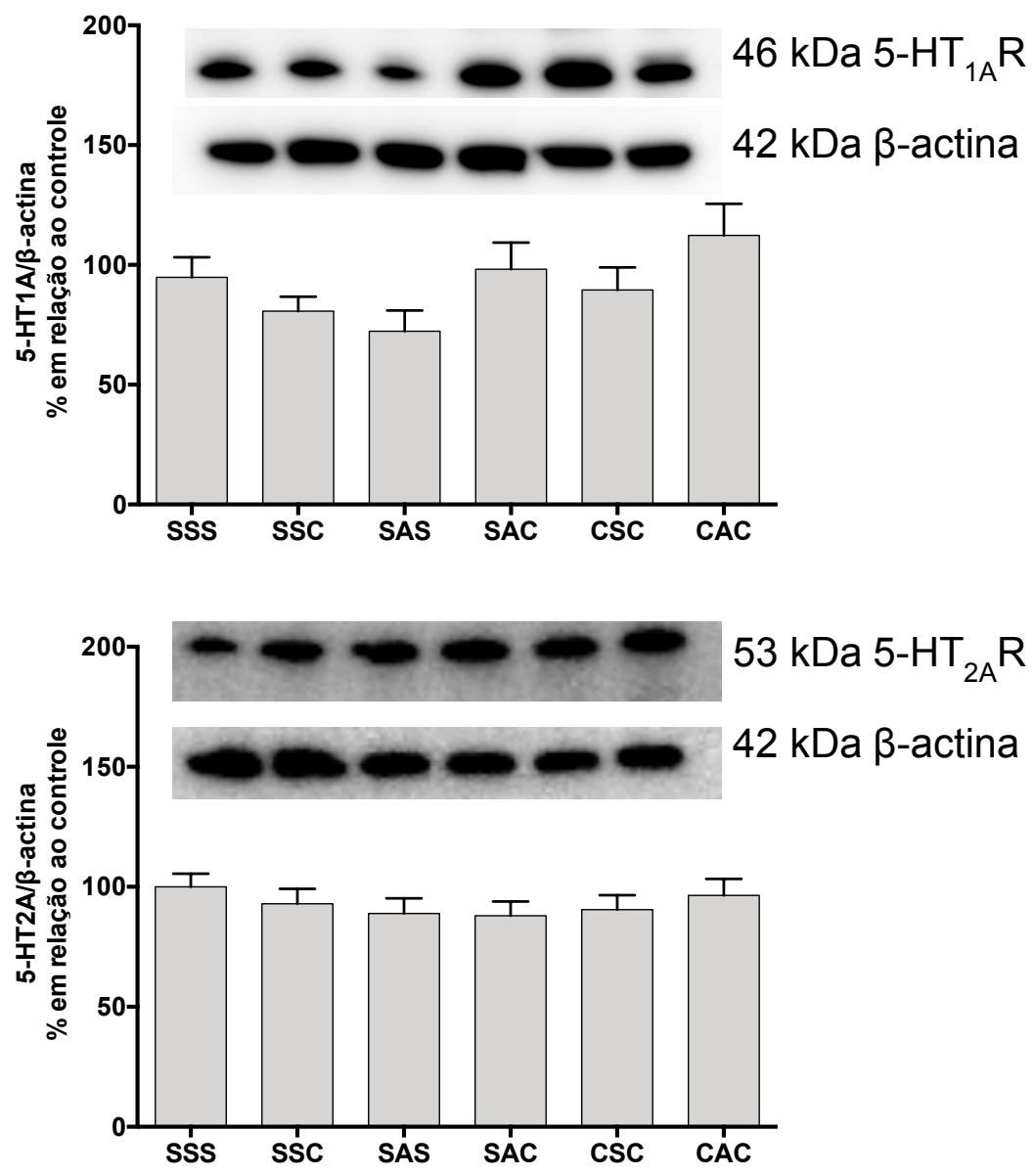
Discussão 


\section{Discussão}

Nos últimos anos, observou-se grande aumento das estatísticas envolvendo a cocaína no âmbito do consumo, tráfico, apreensão e produção. Em 2013, a agência da União Europeia (Europol) estimou que aproximadamente $30 \%$ das organizações criminosas europeias se relacionavam com mais de um crime, sendo o tráfico de drogas presente em mais de 50\%. Já em 2017, esses mesmos dados subiram para 45 e 65\%, respectivamente. Ainda, é possível estabelecer ligações diretas entre o tráfico de drogas com a fabricação de mercadorias falsas, tráfico de seres humanos e até mesmo de arma. Além disso, estima-se que ao administrar uma droga injetável, o indivíduo se torna cerca de 28 vezes mais propenso a viver com HIV. Segundo a UNAIDS, um programa das Nações Unidas que combate a AIDS, em 2014, cerca de 11,7 milhões de pessoas utilizaram alguma droga pela via intravenosa e aproximadamente 14\% (1,6 milhões) dessas pessoas vivem com HIV (UNODC, 2017).

O interesse no estudo dos alucinógenos cresceu ultimamente com o intuito de avaliar seus possíveis efeitos terapêuticos em doenças psiquiátricas. Em relação à ayahuasca, foram avaliados distúrbios como alcoolismo e tabagismo (BARBOSA et al., 2018), dependência ao crack (CRUZ e NAPPO, 2018); depressão e ansiedade (MUTTONI et al., 2019).

De fato, estudos observacionais em humanos indicam que a ayahuasca e seus alcaloides possuem propriedades ansiolíticas e antidepressivas (CAMERON et al., 2018; DE OSÓRIO et al., 2015; PALHANO-FONTES et al., 2019; SANCHES et al., 2016). Em relação aos estudos em humanos, é possível dizer que a ayahuasca parece atenuar o consumo de diferentes drogas ilícitas, bem como a síndrome de abstinência. Grob e colaboradores (1996) observaram em membros da União do Vegetal, no Brasil, que tomavam ayahuasca regularmente, um declínio no consumo de cocaína, nicotina e/ou anfetamina, além de total abstinência de álcool. Esse mesmo padrão de redução de consumo ou completa abstinência foi observado em membros regulares do Santo Daime nos EUA (HALPERN et al., 2008) e no Brasil (BARBOSA et al., 2008). Loizaga-Velder e Verres (2014) também observaram redução da fissura e de sinais de abstinência em indivíduos passando por terapia assistida com ayahuasca para tratamento da 
dependência de álcool, cocaína e crack na América do Sul, fortalecendo ainda mais a hipótese de que a ayahuasca seria capaz de inibir a expressão da sensibilização à cocaína.

Contudo, é importante salientar que em humanos os efeitos da ayahuasca em amenizar a dependência de drogas estão associados não apenas aos mecanismos bioquímicos das substâncias presentes do chá, mas também a aspectos psicológicos e religiosos. Considerando que o chá é ingerido em rituais e em grupos religiosos onde o consumo de substâncias ilícitas é desencorajado ou proibido, seus membros acabam sendo menos susceptíveis ao desenvolvimento da dependência (LABATE e FEENEY, 2011). Além disso, as experiências místicas vivenciadas sob a vigência dos efeitos alucinógenos parecem facilitar o tratamento. Em um estudo aberto para tratamento do tabagismo com psilocibina, 15 fumantes receberam 2 ou 3 doses de psilocibina. Ao término da terapia, doze participantes permaneceram em abstinência tabágica por 6 meses. Ao comparar os efeitos subjetivos da psilocibina entre o grupo de pessoas que atingiram a abstinência e o que recaiu, os abstencionistas tiveram pontuação significativamente maior em uma medida de experiência mística ocasionada pela psilocibina. Ainda, não foram encontradas diferenças significativas na intensidade dos efeitos do alucinógeno entre os grupos, sugerindo que os efeitos místico foram responsáveis pela cessação do tabagismo (GARCIAROMEU et al., 2014).

Nosso primeiro desafio foi padronizar a dose que seria utilizada nos experimentos, uma vez que o chá de ayahuasca é utilizado em ritual xamânico e, não é um chá padronizado, de forma que a concentração dos alcaloides varia de ritual para ritual e de grupo para grupo. Um agravante é que os estudos pré-clínicos consideraram o chá como um todo quando da sleção da dose e, geralmente, não quantificam seus componentes. Neste sentido, um diferencial deste estudo foi a dosagem dos componentes da ayahuasca utilizada, e a padronização da dose de acordo com a concentração de DMT.

Estudos neurocomportamentais em modelos animais são essenciais no âmbito da avaliação dos efeitos da exposição prolongada às substâncias químicas. Um dos principais modelos comportamentais utilizados consiste no 
teste do campo aberto, com o intuito de avaliar parâmetros como: atividade locomotora, medo e ansiedade (CHOLERIS et al., 2001). A avaliação de roedores em campo aberto é utilizada em paradigmas comportamentais que buscam mimetizar determinados aspectos da farmacodependência. Em nosso primeiro estudo, foi analisada a influência de diversas doses de ayahuasca na atividade locomotora de camundongos. Para tanto, os animais foram habituados no aparato de CA por 1 hora durante dois dias consecutivos. Sabe-se que camundongos possuem instinto inato em explorar novos ambientes. Dessa forma, são necessários pelo menos dois dias de habituação no CA a fim de suprimir a atividade locomotora procedente da atividade exploratória. Após o período de habituação, os animais foram divididos em grupos, recebendo ayahuasca por gavagem nas seguintes doses 1,76; 3; 17,6 e 30 mg de DMT/kg.

A administração aguda de ayahuasca não alterou significativamente a atividade locomotora dos animais. No entanto, foi possível notar um perfil característico para as doses. Os animais que foram tratados com ayahuasca na dose de 1,76 mg de DMT/kg percorreram uma distância maior que a dos outros grupos, os camundongos que foram tratados com $3 \mathrm{mg}$ de DMT/kg tiveram o mesmo perfil locomotor no CA que o grupo controle, tanto em relação à atividade locomotora total, quanto intervalada em 15 ou 30 minutos. Os camundongos que foram tratados com doses superiores $(17,6$ e $30 \mathrm{mg}$ de $\mathrm{DMT} / \mathrm{kg}$ ) possuíram perfil de atividade locomotora semelhante.

Apesar de a DMT ser um agonista do receptor 5- $\mathrm{HT}_{2 \mathrm{~A}}$ e $5-\mathrm{HT}_{2 \mathrm{C}}$, estudos mostram que ela possui maior afinidade pelos receptores $5-\mathrm{HT}_{2 \mathrm{~A}}$ em comparação aos receptores $5-\mathrm{HT}_{2 \mathrm{C}}$. Ainda, Cata-Preta e colaboradores (2018) sugerem que a ativação de receptores $5-\mathrm{HT}_{2}$ induzida pela DMT teria propriedades recompensadoras distintas dependendo da dose administrada. Dessa forma, em doses baixas a intermediárias, a DMT se ligaria preferencialmente aos receptores $5-\mathrm{HT}_{2 \mathrm{~A}}$, o que mediaria suas propriedades psicoestimulantes, ao passo que em doses mais altas, ativaria os receptores 5-HT $2 \mathrm{C}$ (HOWELL e CUNNINGHAM, 2015).

Os receptores 5- $\mathrm{HT}_{2 \mathrm{~A}}$ estão muito presentes em neurônios dopaminérgicos na VTA e, uma vez ativados pela DMT, aumentam as concentrações de dopamina no núcleo accumbens, exercendo os efeitos 
psicomotores. Ao passo que a ativação de receptores $5-\mathrm{HT}_{2 \mathrm{C}}$, que são altamente expressos em interneurônios GABAérgicos na VTA, antagonizam os efeitos da ativação do receptor $5-\mathrm{HT}_{2 \mathrm{~A}}$, reduzindo as concentrações de dopamina no núcleo accumbens (HOWELL e CUNNINGHAM, 2015). Com base nesses resultados, seguimos os experimentos utilizando as doses 1,76 e $3 \mathrm{mg}$ de DMT/kg, uma vez que essas não sugerem possível hipolocomoção na atividade locomotora dos animais.

Assim, realizamos o protocolo de prevenção da expressão da sensibilização comportamental induzida pela cocaína, utilizando inicialmente a administração de ayahuasca na dose de 1,76 mg de DMT/kg durante 8 dias consecutivos. Vale destacar que essa dose mostrou-se eficaz no tratamento da depressão (SAMPEDRO et al., 2017). Durante o período da sensibilização comportamental pela cocaína, notou-se aumento progressivo na atividade locomotora dos camundongos tratados com a droga ao longo dos dias. Já no segundo dia de administração de cocaína, observou-se a aquisição da sensibilização comportamental.

Contudo, a ayahuasca na dose $1,76 \mathrm{mg}$ de DMT/kg não foi capaz de prevenir a expressão da sensibilização comportamental induzida pela cocaína. Nossas hipóteses para explicar esse resultado envolviam: o " $n$ " experimental que poderia ter sido baixo ou a dose de ayahuasca que não adequada. Interessante destacar que um estudo realizado por colaborador de nosso grupo de pesquisa na UNIFAL, ainda não publicado, mostrou que a de $1,76 \mathrm{mg}$ de $\mathrm{DMT} / \mathrm{kg}$ foi eficaz em proteger a expressão da sensibilização comportamental de camundongos Swiss produzida pelo etanol (ALMEIDA, 2019), sugerindo que o efeito da ayahuasca pode variar entre as diferentes drogas. Esse resultado corrobora com os de Oliveira-Lima e colaboradores (2015), os quais observaram que a ayahuasca nas doses de 100 e $300 \mathrm{mg} / \mathrm{kg}$ foi eficiente em bloquear a expressão da sensibilização induzida pelo etanol em camundongos C57BI/6 após 8 dias de tratamento.

Ainda, nesse mesmo protocolo, realizamos o experimento de labirinto em cruz elevado (LCE) após 7 administrações do alucinógeno e não observamos diferença estatística ao comparar os grupos experimentais em relação a entrada tanto nos braços fechados ou abertos ou no tempo de permanência em cada uma dessas áreas. Nossa hipótese é que a dose 
utilizada nesse experimento era baixa, o que é reforçado pelos resultados de Correa-Netto e colaboradores (2017). Esses autores avaliaram o efeito ansiolítico do chá, tratando camundongos C57BI/6 machos dos 6 aos 18 meses de vida com duas administrações semanais de ayahuasca ( $3 \mathrm{mg}$ de $\mathrm{DMT} / \mathrm{kg}$ v.o.). Ao término de 100 administrações, observaram a redução no número de entrada nos braços fechados pelos animais tratados.

O substrato neurobiológico da sensibilização comportamental à cocaína é o incremento da neurotransmissão mesocorticolímbica dopaminérgica com influência das vias glutamatérgicas (KALIVAS, 2009). De fato, estudos indicam que doses de cocaína a partir de $10 \mathrm{mg} / \mathrm{kg}$, possuem o potencial de induzir essas alterações neuroplásticas, associadas ao aumento do tônus do sistema mesolímbico dopaminérgico (CHEN et al., 2009).

Sabe-se que o ambiente em que a droga é administrada (caixa moradia ou caixa teste) afeta diretamente $\mathrm{o}$ desenvolvimento da sensibilização (SMITH et al, 2016). Neste estudo, optamos por administrar a cocaína aos animais em um ambiente distinto à caixa moradia e encaminhálos diretamente ao campo aberto, a fim de que os efeitos da droga fossem associados ao aparato, produzindo uma sensibilização mais robusta e induzido um aprendizado condicionado entre a droga e o ambiente. Para evitar que a atividade locomotora induzida pela cocaína fosse sinérgica à atividade exploratória de um ambiente novo, os animais foram habituados durante dois dias ao CA. Conforme observado em nossos resultados, não houve diferença significativa entre a atividade dos animais no período de habituação; e os animais tratados com salina 0,9\% i.p. na fase de sensibilização apresentaram atividade locomotora semelhante à desenvolvida durante a habituação, certificando que os resultados obtidos no grupo tratado eram consequência da ação da cocaína e não decorrentes apenas de atividade exploratória.

Os estudos de sensibilização comportamental permitem avaliar alterações neurobiológicas duradouras induzidas pela administração repetida de determinada droga (SMITH et al, 2016). Dependendo do protocolo de tratamento empregado, a sensibilização pode ser acessada mesmo após longos períodos de abstinência (HENRY e WHITE, 1995; MARIN et al., 2009; SHUSTER et al., 1977; SMITH et al., 2014). Em modelos pré-clínicos de 
sensibilização, os animais, quando desafiados com uma reexposição à droga, após um período de abstinência, apresentam elevação das concentrações de dopamina no núcleo accumbens (JUNG et al., 2013). Quando o foco dos estudos é um possível tratamento ou atenuação dos efeitos da dependência, são conduzidos protocolos de extinção, onde a substância de interesse é administrada na ausência da droga, porém, no mesmo ambiente e o efeito desta é avaliada após um desafio, esperando-se que a expressão da sensibilização seja suprimida (OLIVEIRA-LIMA et al., 2015; PENZNER et al., 2008; ZAMBRANA-INFANTES et al., 2018).

A administração repetitiva ou então $\circ$ uso excessivo de substâncias reforçadoras origina sintomas de psicose e até mesmo alucinações. Todavia, drogas que reduzem a liberação de dopamina e bloqueiam os receptores $D_{2}$, reduzindo os níveis de dopamina no cérebro, tendem a reduzir ou até mesmo cessar esses sintomas (STAHL, 2008). Apesar de parecer controverso tratar os dependentes com substâncias classificadas como substâncias do grupo 1 , os alucinógenos têm se mostrado efetivos no tratamento de diferentes condições (WINKELMAN, 2014). Há de se considerar que tais substâncias apresentam bom perfil de segurança, já que os índices de mortalidade associados a seu consumo são baixos (FRECSKA, 2007; HALPERN et al., 2008). Além disso, essas substâncias não possuem capacidade de induzir dependência e os períodos de "after-glow", consequentes de ação no sistema serotoninérgico são eficazes na manutenção da abstinência de substâncias por até meses (MCKIN, 1991). De fato, as concentrações de serotonina nos indivíduos dependentes estão reduzidos, prejudicando o funcionamento desse sistema e de seu papel neuromodulatório sobre a dopamina (WINKELMAN, 2014)

O passo seguinte foi aumentar a dose de ayahuasca para $3 \mathrm{mg}$ de DMT/kg. Houve a necessidade de alterar alguns parâmetros do protocolo experimental, a fim de melhorar a análise, sendo então: (i) aumentar o tempo de permanência dos camundongos no aparado do CA de 10 para 30 minutos para melhor quantificação da atividade locomotora; (ii) aumentar o tempo de habituação dos camundongos no aparato de CA de 2 para 3 dias para melhor homogeneização da atividade locomotora dos grupos salina e cocaína; (iii) 
inserir um desafio com salina um dia antes do desafio com cocaína a fim de avaliar a extinção do comportamento associativo cocaína-ambiente.

Apesar dessas alterações, a dose de $3 \mathrm{mg}$ de DMT/kg, no âmbito comportamental, também não foi capaz de reverter os efeitos psicoestimulante desencadeados pelo uso da cocaína, uma vez que o grupo CAC após o tratamento crônico de 8 dias consecutivos expressou a sensibilização induzida pela cocaína no último dia do protocolo experimental ao ser desafiado com cocaína.

Palhano-Fontes et al. (2019) testaram os efeitos antidepressivos utilizando única dose única de ayahuasca em um estudo duplo-cego com 29 pacientes diagnosticados com depressão e resistente ao tratamento. Os autores observaram que os escores, baseados na escala de avaliação de depressão de Montgomery-Åsberg e na escala de avaliação de depressão de Hamilton e relativos à depressão estavam menores no grupo tratado com ayahuasca do que no grupo tratado com placebo já no primeiro dia de análise. Mais ainda, a taxa de resposta foi mais alta após sete dias da administração da ayahuasca.

Tento em vista os efeitos antidepressivos da ayahuasca, promovidos pela administração aguda na redução dos sintomas relacionados à depressão, realizamos um experimento comportamental, a fim de verificar se uma dose de ayahuasca (3 $\mathrm{mg}$ de DMT/kg) anterior à administração de cocaína poderia atenuar ou suprimir seus efeitos psicomotores na atividade locomotora de camundongos $\mathrm{C} 5 \mathrm{BI} / 6$. No entanto, ao desafiarmos com cocaína os grupos que inicialmente foram tratados com água filtrada e ayahuasca na dose de $3 \mathrm{mg}$ de DMT/kg, ambos os grupos desempenharam atividade locomotora semelhante no término do experimento, sugerindo que a administração aguda desta dose não é capaz de bloquear os efeitos psicoestimulantes da cocaína.

Vale ressaltar que os modelos experimentais utilizando animais fornecem respaldo científico e fortalecem as investigações sobre efeitos comportamentais e neuroquímicos da ayahuasca, porém sem a associação ao uso ritualístico ou espiritual (CORREA-NETTO et al., 2017). É possível também que as propriedades terapêuticas da ayahuasca partam da alteração na atividade cerebral induzida por ela, como a intensificação da atividade de 
regiões frontais e paralímbicas associadas ao processamento emocional e fatores mnemônicos, ou decréscimo da atividade de regiões corticais envolvidas na introspecção e na consciência (BOUSO et al., 2013)

Pic-Taylor e colaboradores (2015) mostraram a alta ativação neuronal pela a análise de $c$-fos na parte dorsal dos núcleos dorsais da rafe após $2 \mathrm{~h}$ da administração de ayahuasca na dose de $9 \mathrm{mg}$ de DMT/kg. Este aumento também foi identificado no núcleo amidaloide e em regiões do hipocampo (giro denteado, CA1, CA2 e CA3), as quais representam áreas importantes das vias serotoninérgicas envolvidas na modulação de respostas comportamentais em modelos animais de ansiedade ou depressão.

O grupo de pesquisa de Lindsay $\mathrm{P}$. Cameron da Universidade da Califórnia mostrou os efeitos ansiolíticos e antidepressivos da DMT isolada utilizando ratos Sprague-Dawley adultos. Eles utilizaram $10 \mathrm{mg} / \mathrm{kg}$ de DMT, uma vez que essa dose, quando convertido para uma dose equivalente humana utilizando escala alométrica, representa uma dose alucinógena (STRASSMAN et al., 1994), sugerindo que a ayahuasca pudesse ainda ser utilizada frente à depressão e transtorno de estresse pós-traumático.

Sabendo os efeitos desencadeados por essas doses de ayahuasca e conhecendo os efeitos robustos da neuroplasticidade induzida pela cocaína, realizamos uma triagem de doses utilizando o protocolo de doses repetidas para a prevenção à sensibilização comportamental, aumentando as doses para 15, 30 e $45 \mathrm{mg} / \mathrm{kg}$ de DMT. Assim, os camundongos foram tratados com $10 \mathrm{mg} / \mathrm{kg}$ de cocaína por 10 dias alternados, tratados com ayahuasca por 8 dias consecutivos e após 48h, desafiados com cocaína. Como resultado, vimos que a atividade locomotora do grupo tratado (CAC) foi inferior a do grupo não tratado (CSC), sugerindo que a ayahuasca nessas doses superiores é capaz de prevenir a expressão da sensibilização comportamental induzida pela cocaína, sendo a ayahuasca contendo $15 \mathrm{mg}$ de DMT/kg a menor dose encontrada capaz de atenuar esse fenômeno.

É importante pontuar que, no protocolo utilizado, o desafio cocaína acontece 48h após o término do tratamento com ayahuasca e, considerando a meia vida da DMT de 259 minutos (CALLAWAY et al., 1999), infere-se que essa substância não está mais presente no organismo dos animais, sugerindo que os efeitos de redução na atividade locomotora se deva às 
alterações de longo prazo na circuitaria do sistema nervoso central dos camundongos tratados com ayahuasca.

Apesar de não haver um mecanismo de ação dos alucinógenos frente à farmacodependência induzida por drogas de abuso, Bogenschutz e colaboradores (2012) sugerem que esses efeitos partem de três princípios: (i) dos efeitos agudos desencadeados por essas substâncias, os quais estão relacionados à ativação, primeiramente, de receptores $5-\mathrm{HT}$ e de receptores glutamatérgicos; (ii) dos efeitos agudos psicológicos relacionados à experiência mística ou aos insights psicológicos, provenientes das mirações e (iii) dos efeitos de longa duração ou persistentes, os quais correspondem aos efeitos de neuroplasticidade, que consiste na capacidade do cérebro em remodelar suas conexões funcional e estruturalmente em resposta a um estímulo. Essas alterações ocorrem em vários níveis tanto em mudanças moleculares em sinapses (plasticidade sináptica) quanto em mudanças envolvidas no remapeamento de neurocircuitos (KORPI et al., 2015).

Com auxílio da bioinformática, Petri e colaboradores (2014) compararam a atividade cerebral funcional em estado de repouso de 15 voluntários saudáveis após a infusão intravenosa de placebo e psilocibina $(0,2 \mathrm{mg} / \mathrm{ml})$. Os resultados mostram que a estrutura homológica dos padrões funcionais do cérebro sofre alteração significativa, sugerindo que, sob o efeito dessa alucinógeno, novos elos entre regiões do cérebro previamente desconectadas são criados, alterando temporariamente toda a estrutura organizacional do cérebro.

Em um trabalho recente, um grupo de pesquisa da Universidade de Johns Hopkins mostrou que o período crítico para a aprendizagem da recompensa social em camundongos é durante a puberdade e diminui quando se tornam adultos. Após tratamento com MDMA (10 mg/kg i.p.), a maioria dos animais respondeu às interações sociais da mesma forma que os camundongos jovens. Este efeito durou pelo menos duas semanas e o mesmo não foi observado no grupo que recebeu injeções de salina (NARDOU et al., 2019).

Calvin Ly e colaboradores (2018) evidenciaram a capacidade dos alucinógenos das classes das anfetaminas (como o DOI), ergolinas, triptaminas e ibogainas de promoverem a plasticidade na estrutura neuronal. 
Usando microscopia de iluminação estruturada de superresolução, os autores mostraram que os alucinógenos aumentam a densidade de espinhos dendríticos em neurônios corticais. Ainda, usando a DMT, verificaram que, in vivo, a densidade dos neurônios aumenta e que essas alterações na plasticidade estrutural são acompanhadas por efeitos funcionais, como aumento da amplitude e da frequência de correntes espontâneas póssinápticas excitatórias espontâneas.

Morales-Garcia e colaboradores (2017) mostraram, por meio de um modelo in vitro, que após tratamento de células-troncos neurais adultas com $1 \mu \mathrm{M}$ das $\beta$-carbolinas presentes na ayahuasca e um dos metabólitos da harmina, o harmalol, houve a regulação da atividade, estimulando a proliferação e sua diferenciação dessas células predominantemente em neurônios.

Ainda, é importante lembrar que a ação da ayahuasca não provém apenas da DMT, uma vez que em sua composição também há presença de $\beta$-carbolinas, como harmalina, harmina e tetrahidroharmina. Em modelos animais, há estudos que demonstraram efeitos positivos dessas substâncias isoladamente em diferentes aspectos biológicos da dependência, tornando-as substâncias promissoras ao tratamento da farmacodependência. Glick e colaboradores (1994) avaliaram os efeitos da harmalina (também presente na ibogaína) na autoadministração de cocaína e morfina por ratos. Uma única injeção (via i.p.) desse alcaloide promoveu decréscimo dose dependente da autoadministração de ambas as drogas, uma hora após o tratamento. Ainda, em alguns animais, esse efeito persistiu por dias. Além disso, Aricioglu-Kartal e colaboradores (2003) observaram que 5 e $10 \mathrm{mg} / \mathrm{kg}$ de harmina i.p. também foi capaz de atenuar a síndrome de abstinência induzida pela morfina. Os efeitos dessa $\beta$-carbolina também foram avaliados por Brierly e Davidson (2013) em fatias cerebrais de ratos, onde $300 \mathrm{nM}$ produziu aumento no efluxo de dopamina no shell do núcleo accumbens, porém não no core; e, quando coadministrada com cocaína, esses efeitos foram aditivos. Este mecanismo foi independente da MAO e a injeção de antagonista 5$\mathrm{HT}_{2 \mathrm{~A} / 2 \mathrm{C}}$ promoveu bloqueio do mesmo, sugerindo que os efeitos da harmina na transmissão dopaminérgica são mediados pela serotonina. 
Além de interagirem com o sistema serotoninérgico, os componentes da ayahuasca também são capazes de modular a transmissão dopaminérgica. Análises de SPECT (tomografia computadorizada por emissão de fóton único) mostraram aumento da perfusão sanguínea no núcleo accumbens após a administração da ayahuasca em pacientes depressivos (SANCHES et al., 2016). Ademais, a psilocibina, alucinógeno agonista $5-\mathrm{HT}_{2 \mathrm{~A}}$ química e farmacologicamente semelhante ao DMT elevou as concentrações de dopamina na região estriatal do caudado-putâmen (VOLLENWEIDER et al., 1999). Este composto também apresentou efeito protetor para a dependência de álcool e nicotina (BARBOSA et al., 2018; GARCIA-ROMEU et al., 2014; JOHNSON et al., 2014).

Nossos experimentos mostram a capacidade da ayahuasca, na dose de $15 \mathrm{mg}$ de DMT/kg, em prevenir a expressão da sensibilização comportamental induzida pela cocaína após 8 dias consecutivos de administração. No entanto, ao avaliar os receptores $5-\mathrm{HT}_{1 \mathrm{~A}}$ e $5-\mathrm{HT}_{2 \mathrm{~A}}$ no córtex pré-frontal, estriado e hipocampo por immunoblotting, não foram observadas diferenças significativas, sugerindo que talvez a técnica utilizada não seja sensível suficiente para detectar as alterações induzidas pelo tratamento ou porque o mecanismo de atuação da ayahuasca neste contexto seja mediado por outras vias ou receptores, pois os alucinógenos clássicos podem estimular o sistema serotoninérgico por meio dos receptores $5-\mathrm{HT}_{2 \mathrm{C}} \mathrm{e}$ $5-\mathrm{HT}_{7}$, o sistema dopaminérgico principalmente via receptores $D_{2}$ e indiretamente com os sistemas glutamatérgico e GABAérgico (BARSUGLIA et al., 2018; DE GREGORIO et ai., 2018).

A presença de receptores $5-\mathrm{HT}_{2 \mathrm{C}}$ em interneurônios GABAérgicos, especialmente na área tegmental ventral e córtex pré-frontal, sugere que a ativação desses receptores inibe a neurotransmissão mesolímbica dopaminérgica. Estudos pré-clínicos sugerem que agonistas desses receptores serotoninérgicos reduziriam os efeitos subjetivos e reforçadores da cocaína em pacientes expostos à droga durante a recuperação (HOWELL e CUNNINGHAM, 2015). Ainda, o desequilíbrio associado ao receptor $5-\mathrm{HT}_{2 \mathrm{C}}$ é dito como fortalecedor de doenças relacionadas à recompensa, como esquizofrenia, depressão e dependência (SUMIYOSHI et al., 2014). 
A ayahuasca tem sido grande foco dos estudos em relação à redução de danos ocasionados por drogas de abuso posto que, alucinógenos, no geral, apresentam maior perfil de segurança, baixos índices de mortalidade e pouco potencial para indução da farmacodependência (NUTT et al., 2007; NUTT et al., 2010). Nossos dados corroboram a literatura sobre a questão do uso da ayahuasca e na questão da redução de danos relativos às drogas de abuso. Os mecanismos envolvidos ainda precisam ser melhor explorados. Este é um estudo pré-clínico que contribuirá para a consolidação dos conhecimentos científicos na área de farmacodependência e seus tratamentos, com a finalidade de produzir métodos mais eficazes no tratamento em relação à dependência em cocaína e de suas consequências. 
Conclusão 


\section{Conclusão}

- Ayahuasca em baixas doses (1,76 e $3 \mathrm{mg} / \mathrm{kg}$ de DMT) não é eficaz em prevenir a expressão da sensibilização comportamental à cocaína em camundongos após 8 dias de tratamento;

- A ayahuasca na dose de 1,76 mg/kg de DMT não foi capaz de induzir efeitos ansiolíticos em camundongos observados no LCE após 7 dias de tratamento;

- Doses superiores de ayahuasca (15, 30 e $45 \mathrm{mg} / \mathrm{kg}$ de DMT) se mostram eficazes em prevenir a expressão da sensibilização comportamental à cocaína após 8 dias de tratamento em camundongos;

- Não houve alteração na quantificação dos receptores serotoninérgicos $5-\mathrm{HT}_{1 \mathrm{~A}}$ e $5-\mathrm{HT}_{2 \mathrm{~A}}$ nas regiões encefálicas córtex pré-frontal, estriado e hipocampo após o tratamento com ayahuasca na dose de $15 \mathrm{mg} / \mathrm{kg}$ de DMT. 
Referências Bibliográficas 


\section{Referências Bibliográficas}

ALMEIDA, C. A. F. Ayahuasca no tratamento da farmacodependência ao etanol em camundongos: possível intervenção terapêutica? 2019. Dissertação (Mestrado em Farmácia) - Faculdade de Ciências Farmacêuticas, Universidade Federal de Alfenas, Minas Gerais.

ALPER, Kenneth et al. LSD Administered as a Single Dose Reduces Alcohol Consumption in C57BL/6J Mice. Frontiers in pharmacology, v. 9, p. 994, 2018. Disponivel em: <http://www.ncbi.nlm.nih.gov/pubmed/30233372>.

BANNON, Michael J. e KAPATOS, Gregory e ALBERTSON, Dawn N. Gene expression profiling in the brains of human cocaine abusers. Addiction Biology. [S.I: s.n.]. , Mar 2005

BARBOSA, Paulo Cesar Ribeiro et al. Assessment of Alcohol and Tobacco Use Disorders Among Religious Users of Ayahuasca. Frontiers in psychiatry, v. 9, p. 136, 2018. Disponível em: <http://www.ncbi.nlm.nih.gov/pubmed/29740355>.

BARR, Alasdair M e MARKOU, Athina. Psychostimulant withdrawal as an inducing condition in animal models of depression. Neuroscience and biobehavioral reviews, $v$. 29, n. 4-5, p. 675-706, 2005. Disponível em: <http://www.ncbi.nlm.nih.gov/pubmed/15893821>.

BARSUGLIA, Joseph et al. Intensity of Mystical Experiences Occasioned by 5-MeO-DMT and Comparison With a Prior Psilocybin Study. Frontiers in psychology, v. 9, p. 2459, 2018. Disponível em: <http://www.ncbi.nlm.nih.gov/pubmed/30574112>.

BERGER, B e GASPAR, P e VERNEY, C. Dopaminergic innervation of the cerebral cortex: unexpected differences between rodents and primates.[erratum appears in Trends Neurosci 1991 Mar;14(3):119]. [Review] [52 refs]. Trends in neurosciences, v. 14, n. 1966, p. 21-27, 1991.

BERRIDGE, Craig W e ARNSTEN, Amy F T. Psychostimulants and motivated behavior: arousal and cognition. Neuroscience and biobehavioral reviews, v. 37, n. 9 Pt A, p. 1976-84, Nov 2013. Disponível em: <http://www.ncbi.nlm.nih.gov/pubmed/23164814>.

BERRIDGE, Kent $C$ e ROBINSON, Terry E. Liking, wanting, and the incentivesensitization theory of addiction. The American psychologist, v. 71 , n. 8, p. 670-679, Nov 2016. Disponível em: <http://www.ncbi.nlm.nih.gov/pubmed/27977239>.

BOGENSCHUTZ, Michael P e POMMY, Jessica M. Therapeutic mechanisms of classic hallucinogens in the treatment of addictions: from indirect evidence to testable hypotheses. Drug testing and analysis, v. 4, n. 7-8, p. 543-55, 2012. Disponível em: $<$ http://www.ncbi.nlm.nih.gov/pubmed/22761106>.

BOUSO, José Carlos et al. Acute effects of ayahuasca on neuropsychological performance: Differences in executive function between experienced and occasional users. Psychopharmacology, v. 230, n. 3, p. 415-424, Dez 2013.

CALLAWAY, J. C. et al. Pharmacokinetics of Hoasca alkaloids in healthy humans. Journal of Ethnopharmacology, v. 65, n. 3, p. 243-256, Jun 1999. 
CAMERON, Lindsay $\mathrm{P}$ et al. Effects of $\mathbf{N}, \mathrm{N}$-Dimethyltryptamine on Rat Behaviors Relevant to Anxiety and Depression. ACS chemical neuroscience, v. 9, n. 7, p. 15821590, 2018. Disponível em: <http://www.ncbi.nlm.nih.gov/pubmed/29664276>.

CARHART-HARRIS, R. L. et al. Psilocybin with psychological support for treatmentresistant depression: six-month follow-up. Psychopharmacology, v. 235, n. 2, p. 399408, 1 Fev 2018.

CARLEZON, William A e DUMAN, Ronald S e NESTLER, Eric J. The many faces of CREB. Trends in neurosciences, v. 28 , n. 8, p. 436-45, Ago 2005. Disponível em: $<$ http://www.ncbi.nlm.nih.gov/pubmed/15982754>.

CHAVKIN, Charles e KOOB, George F. Dynorphin, Dysphoria, and Dependence: the Stress of Addiction. Neuropsychopharmacology: official publication of the American College of Neuropsychopharmacology, v. 41, n. 1, p. 373-4, Jan 2016. Disponível em: $<$ http://www.ncbi.nlm.nih.gov/pubmed/26657953>.

CHEN, Qian et al. Sodium benzoate exposure downregulates the expression of tyrosine hydroxylase and dopamine transporter in dopaminergic neurons in developing zebrafish. Birth Defects Research Part B - Developmental and Reproductive Toxicology, v. 86, n. 2, p. 85-91, Abr 2009.

CHOLERIS, E et al. A detailed ethological analysis of the mouse open field test: effects of diazepam, chlordiazepoxide and an extremely low frequency pulsed magnetic field. Neuroscience and biobehavioral reviews, v. 25, n. 3, p. 235-60, Maio 2001. Disponível em: <http://www.ncbi.nlm.nih.gov/pubmed/11378179>.

COLBY, Christina R. et al. Striatal Cell Type-Specific Overexpression of $\Delta \mathrm{Fos} B$ Enhances Incentive for Cocaine. The Journal of Neuroscience, v. 23, n. 6, p. 24882493, 15 Mar 2003. Disponivel em: $<$ http://www.jneurosci.org/lookup/doi/10.1523/JNEUROSCI.23-06-02488.2003>.

CONE, E J. Pharmacokinetics and pharmacodynamics of cocaine. Journal of analytical toxicology, v. 19 , n. 6 , p. 459-78, Out 1995. Disponível em: <http://www.ncbi.nlm.nih.gov/pubmed/8926741>.

CONSELHO FEDERAL DE MEDICINA. DIRETRIZES GERAIS MÉDICAS Para Assistência Integral ao Dependente do Uso do Crack. 2011. Disponível em http://www.sbp.com.br/pdfs/diretrizes-medicas-integral-crack-cfm.pdf.

CORREA-NETTO, N. F. et al. An ontogenic study of the behavioral effects of chronic intermittent exposure to ayahuasca in mice. Brazilian Journal of Medical and Biological Research, v. 50, n. 7, 2017.

COVINGTON, Herbert E e MICZEK, Klaus A. Vocalizations during withdrawal from opiates and cocaine: possible expressions of affective distress. European journal of pharmacology, v. 467, n. 1-3, p. 1-13, 25 Abr 2003. Disponível em: $<$ http://www.ncbi.nlm.nih.gov/pubmed/12706449>.

CRUZ, Joselaine Ida e NAPPO, Solange Aparecida. Is Ayahuasca an Option for the Treatment of Crack Cocaine Dependence? Journal of psychoactive drugs, v. 50, n. 3, p. 
247-255, 2018. Disponível em: <http://www.ncbi.nlm.nih.gov/pubmed/29608428>.

DE OSÓRIO, Flávia L. et al. Antidepressant effects of a single dose of ayahuasca in patients with recurrent depression: A preliminary report. Revista Brasileira de Psiquiatria, v. 37, n. 1, p. 13-20, 2015.

DE VEEN, Bas T.H. et al. Psilocybin for treating substance use disorders? Expert Review of Neurotherapeutics. [S.I.]: Taylor and Francis Ltd. , 1 Fev 2017

$\mathrm{DOBI}$, Alice et al. Glutamatergic and nonglutamatergic neurons of the ventral tegmental area establish local synaptic contacts with dopaminergic and nondopaminergic neurons. Journal of Neuroscience, v. 30, n. 1, p. 218-229, 6 Jan 2010.

DOMÍNGUEZ-CLAVÉ, Elisabet et al. Ayahuasca: Pharmacology, neuroscience and therapeutic potential. Brain research bulletin, v. 126, n. Pt 1, p. 89-101, 2016. Disponível em: <http://www.ncbi.nlm.nih.gov/pubmed/26976063>.

DUNCAN, D F et al. Harm reduction: an emerging new paradigm for drug education. Journal of drug education, v. 24, n. 4, p. 281-90, 1994. Disponível em: $<$ http://www.ncbi.nlm.nih.gov/pubmed/7869220>.

EMCDDA. European Drug Report. . [S.I: s.n.], 2019. Disponível em: <http://www.a.europa.eu/system/files/publications/11364/20191724_TDAT19001PTN_PD F.pdf>.

ESTRELLA-PARRA, Edgar Antonio e ALMANZA-PÉREZ, Julio Cesar e ALARCÓNAGUILAR, Francisco Javier. Ayahuasca: Uses, Phytochemical and Biological Activities. Natural Products and Bioprospecting, v. 9, n. 4, p. 251-265, Ago 2019.

FRECSKA, Ede. Therapeutic guidelines: dangers and contra-indications in therapeutic applications of hallucinogens. T ROBERTS, M. W. (Org.). . Psychedelic Medicine. [S.I.]: Praeger, 2007. p. pp.69-95.

GARAVAN, $\mathrm{H}$ et al. Cue-induced cocaine craving: neuroanatomical specificity for drug users and drug stimuli. The American journal of psychiatry, v. 157, n. 11, p. 1789-98, Nov 2000. Disponível em: <http://www.ncbi.nlm.nih.gov/pubmed/11058476>.

GARCIA-ROMEU, Albert e GRIFFITHS, Roland R e JOHNSON, Matthew W. Psilocybinoccasioned mystical experiences in the treatment of tobacco addiction. Current drug abuse reviews, $\quad$ v. 7 , n. 3 , p. 157-64, 2014 . Disponível em: <http://www.ncbi.nlm.nih.gov/pubmed/25563443>.

GOLDSTEIN, Rita Z e VOLKOW, Nora D. Drug addiction and its underlying neurobiological basis: neuroimaging evidence for the involvement of the frontal cortex. The American journal of psychiatry, v. 159, n. 10, p. 1642-52, Out 2002. Disponível em: <http://www.ncbi.nlm.nih.gov/pubmed/12359667>.

GRINSPOON, Lester e BAKALAR, James B. Psychedelic drugs reconsidered. [S.I.]: Lindesmith Center, 1997.

HALPERN, John $\mathrm{H}$ et al. Evidence of health and safety in American members of a religion who use a hallucinogenic sacrament. Medical science monitor: international medical journal of experimental and clinical research, v. 14, n. 8, p. SR15-22, Ago 2008. 
Disponível em: <http://www.ncbi.nlm.nih.gov/pubmed/18668010>.

HAMILL, Jonathan et al. Ayahuasca: Psychological and Physiologic Effects, Pharmacology and Potential Uses in Addiction and Mental Illness. Current neuropharmacology, v. $17, \quad$ n. 2 , p. 108-128, 2019. Disponível em: <http://www.ncbi.nlm.nih.gov/pubmed/29366418>.

HENRY, D J e WHITE, F J. The persistence of behavioral sensitization to cocaine parallels enhanced inhibition of nucleus accumbens neurons. The Journal of neuroscience : the official journal of the Society for Neuroscience, v. 15, n. 9, p. 6287-99, Set 1995. Disponível em: <http://www.ncbi.nlm.nih.gov/pubmed/7666211>.

HOWELL, Leonard L. e CUNNINGHAM, Kathryn A. Serotonin 5-HT2 receptor interactions with dopamine function: implications for therapeutics in cocaine use disorder. Pharmacological reviews. [S.I: s.n.]. , 2015

JOHNSON, M. W. e RICHARDS, W. A. e GRIFFITHS, R. R. Human hallucinogen research: Guidelines for safety. Journal of Psychopharmacology. [S.I: s.n.]. , Ago 2008 JOHNSON, Matthew W et al. Pilot study of the 5-HT2AR agonist psilocybin in the treatment of tobacco addiction. Journal of psychopharmacology (Oxford, England), $v$. 28, n. 11, p. 983-92, Nov 2014. Disponível em: <http://www.ncbi.nlm.nih.gov/pubmed/25213996>.

JUNG, Eun-Sol et al. Cocaine-Induced Behavioral Sensitization in Mice: Effects of Microinjection of Dopamine D2 Receptor Antagonist into the Nucleus Accumbens. Experimental Neurobiology, v. 22, n. 3, p. 224, 2013.

KALIVAS, Peter W. The glutamate homeostasis hypothesis of addiction. Nature Reviews Neuroscience. [S.I: s.n.]. , Ago 2009

KELZ, Max B. et al. Expression of the transcription factor $\Delta F o$ B in the brain controls sensitivity to cocaine. Nature, v. 401, n. 6750, p. 272-276, 16 Set 1999.

$\mathrm{KOOB}, \mathrm{George} \mathrm{F}$ et al. Addiction as a stress surfeit disorder. Neuropharmacology, v. 76 Pt B, p. 370-82, Jan 2014. Disponível em: $<$ http://www.ncbi.nlm.nih.gov/pubmed/23747571>.

KOOB, George F e VOLKOW, Nora D. Neurocircuitry of addiction. Neuropsychopharmacology: official publication of the American College of Neuropsychopharmacology, v. 35, n. 1, p. 217-38, Jan 2010. Disponível em: <http://www.ncbi.nlm.nih.gov/pubmed/19710631>.

KORPI, Esa R et al. Mechanisms of Action and Persistent Neuroplasticity by Drugs of Abuse. Pharmacological reviews, v. 67, n. 4, p. 872-1004, Out 2015. Disponível em: <http://www.ncbi.nlm.nih.gov/pubmed/26403687>.

LABATE, B. C. E ARAÚJO, W. S. . 2002. O Uso Ritual da Ayahuasca. CAMPOS - Revista de Antropologia Social, v. 4, p. 211-215, 2003.

LABATE, Beatriz Caiuby e FEENEY, Kevin. 0 processo de regulamentação da ayahuasca no Brasil e na esfera internacional: desafios e implicações. Periferia, v. 3, n. 2, 26 Dez 2011. 
LNUD. III Levantamento Nacional sobre o Uso de Drogas pela População Brasileira. ICICT/FIOCRUZ. 2017

MARIE, Nicolas e CANESTRELLI, Corinne e NOBLE, Florence. Role of pharmacokinetic and pharmacodynamic parameters in neuroadaptations induced by drugs of abuse, with a focus on opioids and psychostimulants. Neuroscience and Biobehavioral Reviews, 2018.

MARIN, Marcelo T. et al. Context-specific modulation of cocaine-induced locomotor sensitization and ERK and CREB phosphorylation in the rat nucleus accumbens. European Journal of Neuroscience, v. 30, n. 10, p. 1931-1940, Nov 2009.

MARKOU, $A$ e KOOB, G F. Postcocaine anhedonia. An animal model of cocaine withdrawal. Neuropsychopharmacology: official publication of the American College of Neuropsychopharmacology, v. 4, n. 1, p. 17-26, Jan 1991. Disponível em: <http://www.ncbi.nlm.nih.gov/pubmed/2003866>.

MASH, Deborah C. et al. Ibogaine detoxification transitions opioid and cocaine abusers between dependence and abstinence: Clinical observations and treatment outcomes. Frontiers in Pharmacology, v. 9, n. JUN, 5 Jun 2018.

MCKENNA, Dennis J. Clinical investigations of the therapeutic potential of ayahuasca: rationale and regulatory challenges. Pharmacology \& therapeutics, v. 102, n. 2, p. 111 29, Maio 2004. Disponível em: <http://www.ncbi.nlm.nih.gov/pubmed/15163593>.

MCKENNA, Dennis e RIBA, Jordi. New world tryptamine hallucinogens and the neuroscience of ayahuasca. Current Topics in Behavioral Neurosciences. [S.I.]: Springer Verlag, 2018. v. 36. p. 283-311.

MISSALE, $C$ et al. Dopamine receptors: from structure to function. Physiological reviews, v. $78, \quad$ n. $1, \quad$ p. 189-225, Jan 1998. Disponível em: $<$ http://www.ncbi.nlm.nih.gov/pubmed/9457173>.

MITHOEFER, Michael C. et al. 3,4-methylenedioxymethamphetamine (MDMA)-assisted psychotherapy for post-traumatic stress disorder in military veterans, firefighters, and police officers: a randomised, double-blind, dose-response, phase 2 clinical trial. The Lancet Psychiatry, v. 5, n. 6, p. 486-497, 1 Jun 2018.

MURNANE, Kevin $S$. The renaissance in psychedelic research: What do preclinical models have to offer. Progress in brain research, v. 242, p. 25-67, 2018. Disponível em: <http://www.ncbi.nlm.nih.gov/pubmed/30471682>.

MUTTONI, Silvia e ARDISSINO, Maddalena e JOHN, Christopher. Classical psychedelics for the treatment of depression and anxiety: A systematic review. Journal of affective disorders, v. 258, p. 11-24, 1 Nov 2019. Disponível em: $<$ http://www.ncbi.nlm.nih.gov/pubmed/31382100>.

NARDOU, Romain et al. Oxytocin-dependent reopening of a social reward learning critical period with MDMA. Nature. [S.I.]: Nature Publishing Group. , 2 Maio 2019

NESTLER, E J. Molecular basis of long-term plasticity underlying addiction. Nature reviews. Neuroscience, v. 2, n. 2, p. 119-28, Fev 2001. Disponível em: 
<http://www.ncbi.nlm.nih.gov/pubmed/11252991>.

NESTLER, Eric J. Epigenetic mechanisms of drug addiction. Neuropharmacology. [S.I: s.n.]. , 2014

NESTLER, Eric J e PH, D. Spp-03-1-4. n. December, p. 4-10, 2005.

NICHOLS, David E. Psychedelics. Pharmacological reviews, v. 68, n. 2, p. 264-355, Abr 2016. Disponível em: <http://www.ncbi.nlm.nih.gov/pubmed/26841800>.

NOLLER, Geoffrey E e FRAMPTON, Chris M e YAZAR-KLOSINSKI, Berra. Ibogaine treatment outcomes for opioid dependence from a twelve-month follow-up observational study. The American journal of drug and alcohol abuse, v. 44, n. 1, p. 3746, 2018. Disponível em: <http://www.ncbi.nlm.nih.gov/pubmed/28402682>.

NUTT, David et al. Development of a rational scale to assess the harm of drugs of potential misuse. Lancet. [S.I.]: Lancet Publishing Group. , 24 Mar 2007

NUTT, David J. e KING, Leslie A. e PHILLIPS, Lawrence D. Drug harms in the UK: A multicriteria decision analysis. The Lancet, v. 376, n. 9752, p. 1558-1565, 6 Nov 2010.

OLIVEIRA-LIMA, A J et al. Effects of ayahuasca on the development of ethanol-induced behavioral sensitization and on a post-sensitization treatment in mice. Physiology \& behavior, v. 142, p. 28-36, 1 Abr 2015. Disponível em: <http://www.ncbi.nlm.nih.gov/pubmed/25637859>.

PALHANO-FONTES, Fernanda et al. Rapid antidepressant effects of the psychedelic ayahuasca in treatment-resistant depression: a randomized placebo-controlled trial. Psychological medicine, v. 49, n. 4, p. 655-663, Mar 2019. Disponível em: $<$ http://www.ncbi.nlm.nih.gov/pubmed/29903051>.

PARVAZ, Muhammad A. et al. Neuroimaging for drug addiction and related behaviors. Reviews in the Neurosciences, v. 22, n. 6, p. 609-624, 1 Dez 2011.

PENZNER, Jeffery $\mathrm{H}$ et al. Protracted "anti-addictive" effects of adolescent phenylpropanolamine exposure in C57BL/6 J mice. Addiction biology, v. 13, n. 3-4, p. 310-25, Set 2008. Disponível em: <http://www.ncbi.nlm.nih.gov/pubmed/18331369>.

ROBINSON, T E e BECKER, J B. Enduring changes in brain and behavior produced by chronic amphetamine administration: a review and evaluation of animal models of amphetamine psychosis. Brain research, v. 396, n. 2, p. 157-98, Jun 1986. Disponível em: <http://www.ncbi.nlm.nih.gov/pubmed/3527341>.

ROBINSON, Terry E. e BERRIDGE, Kent C. The incentive sensitization theory of addiction: Some current issues. 12 Out 2008, [S.I.]: Royal Society, 12 Out 2008. p. 3137-3146.

ROBINSON, Terry E e BERRIDGE, KENT, C. The neural basis of drug craving: an incentive-sensitization theory of addiction. v. 8, p. 247-291, 1993.

ROBINSON, Terry E e BERRIDGE, Kent C. Addiction. Most, v. 54, p. 25-53, 2003. Disponível em: <http://www.ncbi.nlm.nih.gov/pubmed/12185211>.

ROBINSON, Terry E e KOLB, Bryan. Structural plasticity associated with exposure to drugs of abuse. Neuropharmacology, v. 47 Suppl 1, p. 33-46, 2004. Disponível em: <http://www.ncbi.nlm.nih.gov/pubmed/15464124>. 
ROBISON, Alfred J. e NESTLER, Eric J. Transcriptional and epigenetic mechanisms of addiction. Nature Reviews Neuroscience. [S.I: s.n.]. , Nov 2011

RUFFLE, James K. Molecular neurobiology of addiction: what's all the $(\Delta)$ FosB about? The American journal of drug and alcohol abuse, v. 40, n. 6, p. 428-37, Nov 2014. Disponível em: <http://www.ncbi.nlm.nih.gov/pubmed/25083822>.

SAMPEDRO, Frederic et al. Assessing the psychedelic "after-glow" in ayahuasca users: Post-acute neurometabolic and functional connectivity changes are associated with enhanced mindfulness capacities. International Journal of Neuropsychopharmacology, v. 20, n. 9, p. 698-711, 1 Set 2017.

SANCHES, Rafael Faria et al. Antidepressant Effects of a Single Dose of Ayahuasca in Patients With Recurrent Depression: A SPECT Study. Journal of clinical psychopharmacology, v. 36, n. 1, p. 77-81, Fev 2016. Disponível em: <http://www.ncbi.nlm.nih.gov/pubmed/26650973>.

SANTOS, Rafael Guimarães Dos. AYAHUASCA: neuroquímica e farmacologia. SMAD. Revista Eletrônica Saúde Mental Álcool e Drogas (Edição em Português), v. 3, n. 1, p. 1 , 2007.

SCHEIDWEILER, Karl B. et al. Pharmacokinetics of cocaine and metabolites in human oral fluid and correlation with plasma concentrations after controlled administration. Therapeutic Drug Monitoring, v. 32, n. 5, p. 628-637, Out 2010.

SEGAL, D S. Behavioral and neurochemical correlates of repeated d-amphetamine administration. Advances in biochemical psychopharmacology, v. 13, p. 247-62, 1975. Disponivel em: <http://www.ncbi.nlm.nih.gov/pubmed/1171583>.

SHANNON, M. Clinical toxicity of cocaine adulterants. Annals of emergency medicine, v. 17, n. 11, p. 1243-7, Nov 1988. Disponível em: <http://www.ncbi.nlm.nih.gov/pubmed/2903705>.

SHUSTER, Louis e YU, Grace e BATES, Anne. Sensitization to cocaine stimulation in mice. Psychopharmacology, v. 52, n. 2, p. 185-190, Jan 1977.

SMITH, Janette $L$ et al. Deficits in behavioural inhibition in substance abuse and addiction: a meta-analysis. Drug and alcohol dependence, v. 145, p. 1-33, 1 Dez 2014. Disponível em: <http://www.ncbi.nlm.nih.gov/pubmed/25195081>.

STAHL, Stephen M. Do dopamine partial agonists have partial efficacy as antipsychotics? CNS spectrums, v. 13, n. 4, p. 279-82, Abr 2008. Disponível em: $<$ http://www.ncbi.nlm.nih.gov/pubmed/18408646>.

STRASSMAN, R J et al. Dose-response study of $\mathrm{N}, \mathrm{N}$-dimethyltryptamine in humans. II. Subjective effects and preliminary results of a new rating scale. Archives of general psychiatry, v. 51, n. 2, p. 98-108, Fev 1994. Disponível em: <http://www.ncbi.nlm.nih.gov/pubmed/8297217>.

SUMIYOSHI, Tomiki e KUNUGI, Hiroshi e NAKAGOME, Kazuyuki. Serotonin and dopamine receptors in motivational and cognitive disturbances of schizophrenia. Frontiers in Neuroscience, v. 8, n. DEC, 2014. 
TUPPER, Kenneth W. et al. Psychedelic medicine: A re-emerging therapeutic paradigm. CMAJ, v. 187, n. 14, p. 1054-1059, 6 Out 2015.

UNODC. World Drug Report 2017. . [S.I: s.n.], 2018.

UNODC. World Drug Report 2019. . Vienna: [s.n.], 2019.

VALLONE, D e PICETTI, R e BORRELLI, E. Structure and function of dopamine receptors. Neuroscience and biobehavioral reviews, v. 24, n. 1, p. 125-32, Jan 2000. Disponível em: <http://www.ncbi.nlm.nih.gov/pubmed/10654668>.

VOLKOW, N. D. et al. Imaging dopamine's role in drug abuse and addiction. Neuropharmacology. [S.I: s.n.]. , 2009

VOLLENWEIDER, $\mathrm{F} X$ et al. 5-HT modulation of dopamine release in basal ganglia in psilocybin-induced psychosis in man--a PET study with [11C]raclopride. Neuropsychopharmacology: official publication of the American College of Neuropsychopharmacology, v. 20, n. 5, p. 424-33, Maio 1999. Disponível em: <http://www.ncbi.nlm.nih.gov/pubmed/10192823>.

WARNER, E A. Cocaine abuse. Annals of internal medicine, v. 119, n. 3, p. 226-35, 1 Ago 1993. Disponível em: <http://www.ncbi.nlm.nih.gov/pubmed/8323092>.

WEXLER, $B E$ et al. Functional magnetic resonance imaging of cocaine craving. The American journal of psychiatry, v. 158, n. 1, p. 86-95, Jan 2001. Disponível em: $<$ http://www.ncbi.nlm.nih.gov/pubmed/11136638>.

WINKELMAN, Michael. Psychedelics as Medicines for SWinkelman, M. (2014). Psychedelics as Medicines for Substance Abuse Rehabilitation: Evaluating Treatments with LSD, Peyote, Ibogaine and Ayahuasca. Current Drug Abuse Reviews, 7, 101-116. https://doi.org/10.2174/187447370866. Current Drug Abuse Reviews, v. 7, p. 101-116, 2014.

ZAMBRANA-INFANTES, Emma et al. Palmitoylethanolamide attenuates cocaine-induced behavioral sensitization and conditioned place preference in mice. Pharmacology, biochemistry, and behavior, v. 166, p. 1-12, 2018. Disponível em: <http://www.ncbi.nlm.nih.gov/pubmed/29337083>. 
Anexos 


\title{
9. Anexos
}

\subsection{Ficha do aluno}

Janus - Sistema Administrativo da Pós-Graduação

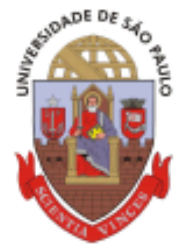

\author{
Universidade de São Paulo \\ Faculdade de Ciências Farmacêuticas \\ Documento sem validade oficial
}

FICHA DO ALUNO

9143 - 7984391/1 - Vítor Bruno

Email:

vitor.bruno@usp.br

Data de Nascimento: 25/02/1993

Cédula de Identidade: $\quad$ RG - 38.671.338-8 - SP

Local de Nascimento: $\quad$ Estado de São Paulo

Nacionalidade: Brasileira

Graduação:

Bacharel em Química - Faculdade de Filosofia, Ciências e Letras de Rỉbeirão Preto - Universidade de São Paulo - São Paulo - Brasil - 2016

Curso:

Mestrado

Programa:

Farmácia (Fisiopatologia e Toxicologia)

Área:

Toxicologia

Data de Matrícula:

$10 / 01 / 2017$

Início da Contagem de Prazo:

$10 / 01 / 2017$

Data Limite para o Depósito:

$07 / 11 / 2019$

Orientador Acadêmico:

Orientador:

Prof(a). Dr(a). Sandro Rogerio de Almeida - 10/01/2017 até 11/04/2017. Email: sandroal@usp.br

Prof(a). Dr(a). Tania Marcourakis - 12/04/2017 até o presente. Email: tmarcour@usp.br

Proficiência em Linguas:

Inglês, Aprovado em 10/01/2017

Prorrogação(ōes):

120 dias

Periodo de 10/07/2019 até 07/11/2019

Data de Aprovação no Exame de

Qualificação:

Aprovado em 09/03/2018

Data do Depósito do Trabalho:

Título do Trabalho:

Data Máxima para Aprovação da

Banca:

Data de Aprovação da Banca:

Data Máxima para Defesa:

Data da Defesa:

Resultado da Defesa:

Histórico de Ocorrências:

Primeira Matrícula em 10/01/2017

Prorrogação em 03/05/2019

Aluno matriculado no Regimento da Pós-Graduação USP (Resolução n 6542 em vigor de 20/04/2013 até 28/03/2018)

Última ocorrência: Matrícula de Acompanhamento em 15/07/2019

Impresso em: 22/08/2019 01:32:18 
Janus - Sistema Administrativo da Pós-Graduaçăo

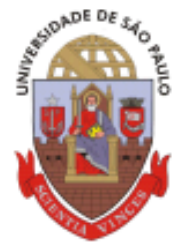

\author{
Universidade de São Paulo \\ Faculdade de Ciências Farmacêuticas \\ Documento sem validade oficial
}

FICHA DO ALUNO

\title{
9143 - 7984391/1 - Vitor Bruno
}

\begin{tabular}{|c|c|c|c|c|c|c|c|c|c|}
\hline Sigla & Nome da Disciplina & Inicio & Término & $\begin{array}{c}\text { Carga } \\
\text { Horária }\end{array}$ & Sred. & Freq. & Conc. & Exc. & Situaçăo \\
\hline $\begin{array}{c}\text { FBC5793- } \\
13 / 1\end{array}$ & $\begin{array}{l}\text { Tópicos em Fisiopatologia e } \\
\text { Toxicologia I }\end{array}$ & 07/03/2017 & 19/06/2017 & 15 & 1 & 89 & A & $\mathrm{N}$ & Concluida \\
\hline $\begin{array}{c}\text { FBC5803- } \\
3 / 9\end{array}$ & $\begin{array}{l}\text { Sistemas de Garantia da Qualidade em } \\
\text { Laboratórios de Ensaio }\end{array}$ & $14 / 03 / 2017$ & 27/03/2017 & 30 & 2 & 100 & A & $\mathrm{N}$ & Concluida \\
\hline $\begin{array}{l}\text { VPT5736- } \\
5 / 2\end{array}$ & $\begin{array}{l}\text { Toxicologia do Sistema Nervoso } \\
\text { Central: Aspectos Bioquimicos } \\
\text { (Faculdade de Medicina Veterinária e } \\
\text { Zootecnia - Universidade de São } \\
\text { Paulo) }\end{array}$ & 08/05/2017 & 18/06/2017 & 90 & 6 & 100 & A & $\mathrm{N}$ & Concluida \\
\hline $\begin{array}{c}\text { FBA5728- } \\
4 / 4\end{array}$ & Aprimoramento Pedagógico & $30 / 05 / 2017$ & $26 / 06 / 2017$ & 60 & 4 & 100 & A & $\mathrm{N}$ & Concluida \\
\hline$\underset{5 / 1}{\text { BMB5795- }}$ & $\begin{array}{l}\text { Neurociência Básica (Instituto de } \\
\text { Ciências Biomédicas - Universidade de } \\
\text { São Paulo) }\end{array}$ & 03/08/2017 & 19/10/2017 & 120 & 8 & 100 & A & $\mathrm{N}$ & Concluida \\
\hline $\begin{array}{c}\text { FBC5818- } \\
3 / 3\end{array}$ & $\begin{array}{l}\text { Neurotoxicidade Provocada por } \\
\text { Xenobióticos e sua Relação com } \\
\text { Doenças Neurodegenerativas }\end{array}$ & 07/05/2018 & $10 / 06 / 2018$ & 45 & 3 & 90 & A & $\mathrm{N}$ & Concluida \\
\hline $\begin{array}{c}\mathrm{FBC} 5885- \\
1 / 1\end{array}$ & $\begin{array}{l}\text { Aplicaçōes de Cromatografia e } \\
\text { Espectrometria de Massas em } \\
\text { Toxicologia }\end{array}$ & 07/05/2018 & $17 / 06 / 2018$ & 90 & 6 & 75 & A & $\mathrm{N}$ & Concluida \\
\hline $\begin{array}{l}\mathrm{FBC} 5757- \\
8 / 2\end{array}$ & $\begin{array}{l}\text { Tópicos em Fisiopatologia e } \\
\text { Toxicologia II }\end{array}$ & 02/08/2018 & $14 / 11 / 2018$ & 15 & 1 & 90 & A & $\mathrm{N}$ & Concluida \\
\hline $\begin{array}{c}\text { BMB5832- } \\
1 / 3\end{array}$ & $\begin{array}{l}\text { Plasticidade Sináptica e Neurobiologia } \\
\text { da Memória (Instituto de Ciências } \\
\text { Biomédicas - Universidade de São } \\
\text { Paulo) }\end{array}$ & 07/11/2018 & $12 / 12 / 2018$ & 60 & 4 & 100 & B & $\mathrm{N}$ & Concluida \\
\hline
\end{tabular}

\begin{tabular}{|c|c|c|c|}
\hline \multicolumn{4}{|c|}{ Créditos mínimos exigidos } \\
\hline & \multicolumn{3}{|c|}{ Para exame de qualificaçẫo Para depósito da dissertaçăo } \\
\hline Disciplinas: & 0 & 25 & 35 \\
\hline \multicolumn{4}{|l|}{ Estágios: } \\
\hline Total: & 0 & 25 & 35 \\
\hline
\end{tabular}

Créditos Atribuídos à Dissertação: 71

\section{Conceito a partir de 02/01/1997:}

A - Excelente, com direito a crédito; B - Bom, com direito a crédito; C - Regular, com direito a crédito; R Reprovado; T - Transferência.

Um(1) crédito equivale a 15 horas de atividade programada. 
9.2. Currículo Lattes

http://lattes.cnpq.br/8316009338654040 


\subsection{Comitê de Ética}

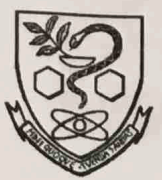

Ofício CEUA/FCF 77.2016-P518

Prezado(a) Senhor(a)

A Comissão de Ética no Uso de Animais da Faculdade de Ciências Farmacêuticas da Universidade de São Paulo (CEUA/FCF/USP), em reunião realizada em 2 de dezembro de 2016, aprovou as alterações propostas para o projeto de pesquisa "Canabidiol e ayahuasca no tratamento da farmacodependência à cocaína: possíveis intervenções terapêuticas?" (Protocolo CEUA $n^{\circ} 518$ ), conforme constante nos documentos apresentados (substituição da linhagem do modelo animal - de Swiss-Webster para C7BL/6J).

Cordialmente,

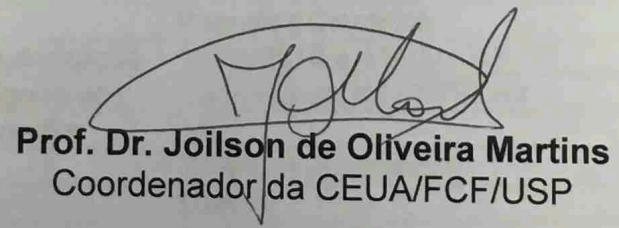

IImo(a). Sr(a)

Pesquisador(a): Profa. Dra. Tania Marcourakis FBC/FCF/USP
FACULDADE DE CIÊNCIAS FARMACÊUTICAS Comissão de Ética no Uso de Animais - CEUA

São Paulo, 6 de dezembro de 2016. 


\subsection{Autorização judicial}

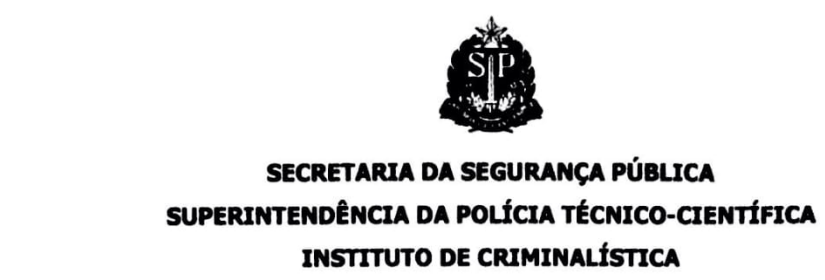

Diretoria do Núcleo de Exames de Entorpecentes do Centro de Exames Análises e Pesquisas

Rua Moncorvo Filho, no 410 Térreo - Butantã - Capital-SP - CEP 05507-060

- (11) 3811-7189 ou 3811-7188 - E-mail: entorpecente.ceap@policiacientifica.sp.gov.br

Ofício 85/2017.

S. Paulo, 14 de novembro de 2017.

Excelentissimo Senhor,

Professor Associado do Departamento de Análises Clínicas e Toxicológicas da Faculdade de Ciências Farmacêuticas da Universidade de São Paulo

Dr. Maurício Yonamine.

Assunto: Requisição Judicial para entrega de amostra de Cocaína. 


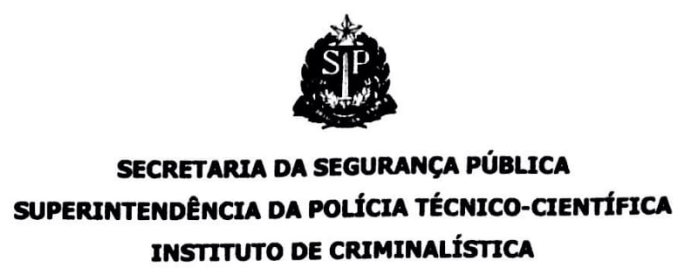

Diretoria do Núcleo de Exames de Entorpecentes do Centro de Exames Análises e Pesquisas

Rua Moncorvo Filho, no 410 Térreo - Butantă - Capital-SP - CEP 05507-060

= (11) 3811 -7189 ou 3811-7188 - E-mail: entorpecente.ceap@policiacientifica.sp.gov.br

\section{Senhor Professor,}

1.

Conforme requisitado no Processo 1517/2017 - DIPO 5.1.1 assinado em 18/10/2017 por MM Juiz de Direito Dr. Paulo de Abreu Lorenzino (cópia anexa), encaminho a V.S $S^{a}$. uma amostra de 200,0g (duzentos gramas) de material compactado de coloração esbranquiçada constituída por Cocaína fechada por lacre número SPTC 427210. Esta amostra refere-se ao Laudo Pericial de número 496.143/2017, no qual consta também a informação quanto da retirada desta amostra.

2.

Sem mais para o momento, com este renovo os protestos de estima e distinta consideração.

Atenciosamente,

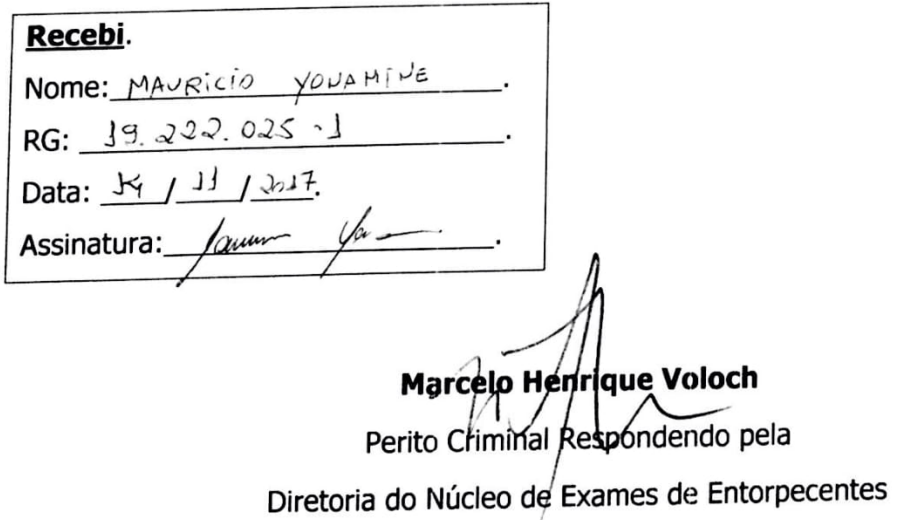


(Consulte o arquivo anexado: 1517-17000.pdf)(Consulte o arquivo anexado: 1517-17.pdf)

JUÍZO DA CORREGEDORIA DA POLÍCIA JUDICIÁRIA - DIPO 5

Av. Dr. Abrahão Ribeiro, no 313 - 20 Pavimento - Rua 7 - sala 468 - Barra Funda - São Paulo/SP - CEP.: 01133-020 - tels. 2127-9620/9621/9622 - dipo5(a tjsp.jus.br

Processo no 1517/17 - DIP0 5.1.1 - jms

São Paulo, 18 de outubro de 2017.

Senhor(a) Diretor(a):

Encaminho a Vossa Senhoria, no anexo, cópias destes autos, que versam sobre pedido de autorização de uso de cocaína em pesquisa científica, para atendimento do quanto determinado no despacho de fls. 23

Ao ensejo, apresento a Vossa Senhoria os meus protestos de elevada estima e distinta consideração.

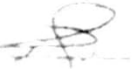

llustríssimo Senhor

DD. Diretor do Instituto de Criminalística

Ro.. Mencorvorilho, 410 - Butantã

CEP.: 05507-060 - São Paulo/SP.[anexo "1517-17000.pdf" removido por SPTC-IC-NEE

Marcelo Henrique Voloch/IC-NEE/SPTC][anexo "1517-17.pdf" removido por SPTC-IC-NEE Marcelo Henrique Voloch/IC-NEE/SPTC] 